WSRC-TR-2007-00008

\title{
Savannah River Site Environmental Report for 2006
}





\section{Acknowledgments}

- The editor acknowledges with deep appreciation the efforts of the following individuals, who (in addition to the chapter authors and compilers) conducted reviews for-and/or contributed valuable resources, information, or technical data to - the Savannah River Site Environmental Report for 2006:

$\begin{array}{llll}\text { Le Anne Barkley } & \text { Chuck Hunter } & \text { Mary Beth Lloyd } & \text { Lisa Oliver } \\ \text { Maureen Bernard } & \text { Laura Janecek } & \text { Donna K. Martin } & \text { Fran Poda } \\ \text { Dean Campbell } & \text { Paul Johns } & \text { Sherrod Maxwell } & \text { Scott Ray } \\ \text { Tiajuana Cochnauer } & \text { Larry Koffman } & \text { Ken McLeod } & \text { D.T. Townsend } \\ \text { Brian Culligan } & \text { Janice Lawson } & \text { Linda Nass } & \text { Rob Turner } \\ \text { Don Faison } & \text { David Lee } & \text { Ross Natoli } & \text { Robin Utsey }\end{array}$

$\underline{\text { Savannah River Ecology Laboratory (SREL) Technical Reviewers: }}$

Dr. Thomas Hinton - Senior Research Scientist, SREL

Dr. Christopher Romanek - Associate Research Scientist, SREL; Associate Professor, Department of Geology, The University of Georgia

Dr. John Seaman - Senior Research Scientist, SREL

Dr. Carl Strojan - Associate Director, SREL

- Listed below are those who provided expert publications support:
Steve Ashe
Rick Daggett
Eleanor Justice
Michelle Norris
Debbie Beckett
Wileva Dunbar
Lisa McCullough
Joan Toole

Gwen Collins

- A special thanks to Mary Baranek for coordinating the DOE-SR review and approval process, which requires dedication and support from both DOE-SR and WSRC:

$\begin{array}{llll}\begin{array}{l}\text { Ben Gould } \\ \text { (DOE-SR) }\end{array} & \begin{array}{l}\text { Gail Whitney } \\ \text { (DOE-SR) }\end{array} & \begin{array}{l}\text { Vernon Gulledge } \\ \text { (WSRC) }\end{array} & \begin{array}{l}\text { Bob Shankle } \\ \text { (WSRC) }\end{array} \\ \text { Amy Poston } & \text { Bruce Cadotte } & \text { Kevin Schmidt } & \\ \text { (DOE-SR) } & \text { (WSRC) } & \text { (WSRC) } & \end{array}$

- Thanks to Rob Clark, Chuck Harvel, Tracey Humphrey, Donnie Tucker, and Ray Wilcauskas for providing computer hardware and software support.

- Marvin Stewart is acknowledged with appreciation for providing Internet expertise. 
- Gratitude is expressed to the following for management, administrative, and other support:

$\begin{array}{llll}\text { Brenda Alejo } & \text { Roslyn Cooke } & \text { Calvin Hamilton } & \text { Wayne Pippen } \\ \text { Patricia Allen } & \text { Sharon Crawford } & \text { Tim Hartley } & \text { Fran Poda } \\ \text { Perry Allen } & \text { Janet Curtis } & \text { Jim Heffner } & \text { Christine Posey } \\ \text { Jackie Banks } & \text { Karl Damon } & \text { Jack Herrington } & \text { Tommy Prickett } \\ \text { Julie Bean } & \text { Daryl Doman } & \text { Minnie Hightower } & \text { Thomasina Robinson } \\ \text { Mary Berry } & \text { Karen Drummings } & \text { Mike Hughes } & \text { Debra Shea } \\ \text { Connie Black } & \text { Dale Duke } & \text { Bill Lewis } & \text { Mark Spires } \\ \text { Tamika Boone } & \text { Ross Fanning } & \text { Cheryl Lewis } & \text { Jim Stafford } \\ \text { Nancy Brown } & \text { Richard Farr } & \text { Bill Macky } & \text { Dan Stewart } \\ \text { Mike Burroughs } & \text { Sylvia Finklin } & \text { Owen Mason } & \text { Becky Sturdivant } \\ \text { Sharon Chapman } & \text { Mary Flora } & \text { Tony Melton } & \text { Robin Wainwright } \\ \text { Becky Chavous } & \text { Lyman Fogle } & \text { Grace Miller } & \text { Kat Williams } \\ \text { Ken Cheeks } & \text { Rodney Gantt } & \text { Ken Mishoe } & \text { Mtesa Wright } \\ \text { Vanessa Cofer } & \text { Brenda Goff } & \text { Ann Odom } & \text { Tommy Young } \\ \text { Gene Cooke } & \text { June Hall } & \text { Karen Palmer } & \end{array}$




\section{To Our Readers}

$\mathrm{S}$ RS has had an extensive environmental monitoring program in place since 1951 (before site startup). In the $1950 \mathrm{~s}$, data generated by the onsite environmental monitoring program were reported in site documents. Beginning in 1959, data from offsite environmental surveillance activities were presented in reports issued for public dissemination. SRS reported onsite and offsite environmental monitoring activities separately until 1985, when data from both programs were merged into one public document. The Savannah River Site Environmental Report for 2006 (WSRC-TR-2007-00008) is an overview of effluent monitoring and environmental surveillance activities conducted on and in the vicinity of SRS from January 1 through December 31, 2006. It is prepared by the Environmental Services Section (ESS) of Washington Savannah River Company (WSRC). The "SRS Environmental Monitoring Plan" (WSRC-3Q1-2-1002) and the "SRS Environmental Monitoring Program" (WSRC-3Q1-2-1100) provide complete program descriptions and document the rationale and design criteria for the monitoring program, the frequency of monitoring and analysis, the specific analytical and sampling procedures, and the quality assurance requirements.

Complete data tables are included on the CD inside the back cover of this report. The CD also features an electronic version of the report; an appendix of site, environmental

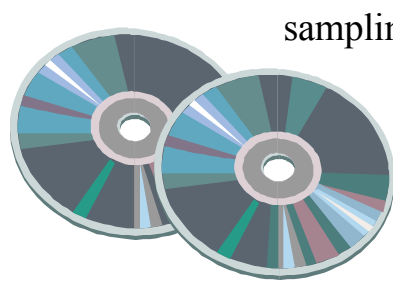

reports from a number of other SRS organizations. Variations in environmental report data reflect year-to-year changes in the routine monitoring program, as well as occasional difficulties in sample collection or analysis. Examples of such difficulties include adverse environmental conditions (such as flooding or drought), sampling or analytical equipment malfunctions, and compromise of the samples in the preparation laboratories or counting room.

The following information should aid the reader in interpreting data in this report:

- Analytical results and their corresponding uncertainty terms generally are reported with up to three significant figures. This is a function of the computer software used and may imply greater accuracy in the reported results than the analyses would allow.

- Units of measure and their abbreviations are defined in the glossary (beginning on page 85 ) and in charts at the back of the report.

- The reported uncertainty of a single measurement reflects only the counting error-not other components of random and systematic error in the measurement process-so some results may imply a greater confidence than the determination would suggest.

- An uncertainty quoted with a mean value represents the standard deviation of the mean value. This number is calculated from the uncertainties of the individual results. For an unweighted mean value, the uncertainty is the sum of the variances for the individual values divided by the number of individual results squared. For a weighted mean 
value, the uncertainty is the sum of the weighted variances for the individual values divided by the square of the sum of the weights.

- All values represent the weighted average of all acceptable analyses of a sample for a particular analyte. Samples may have undergone multiple analyses for quality assurance purposes or to determine if radionuclides are present. For certain radionuclides, quantifiable concentrations may be below the minimum detectable activity of the analysis, in which case the actual concentration value is presented to satisfy DOE reporting guidelines.

- All values represent the weighted average of all acceptable analyses of a sample for a particular analyte. Samples may have undergone multiple analyses for quality assurance purposes or to determine if radionuclides are present. For certain radionuclides, quantifiable concentrations may be below the minimum detectable activity of the analysis, in which case the actual concentration value is presented to satisfy DOE reporting guidelines.

\section{Report Available on Web}

Readers can find the SRS Environmental Report on the World Wide Web at the following address:

http://www.srs.gov/general/pubs/ERsum/index.html

To inquire about the report, please contact

J.D. Heffner, Manager

Environmental Permitting and Monitoring

Washington Savannah River Company

Building 735-B

Aiken, SC 29808

Telephone: $\quad$ 803-952-6931

E-mail address: james.heffner@srs.gov 


\section{Contents}

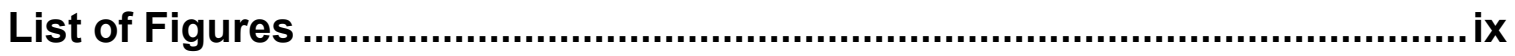

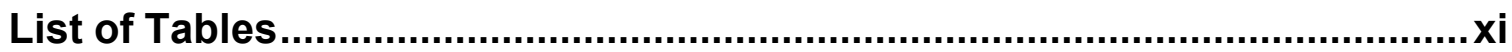

Sampling Location Information ................................................................ii

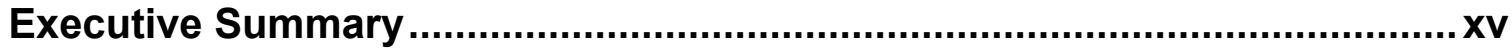

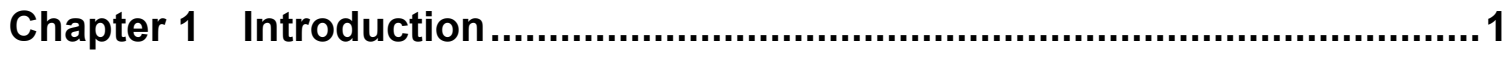

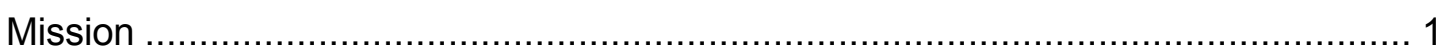

Site Location, Demographics, and Environment.............................................. 1

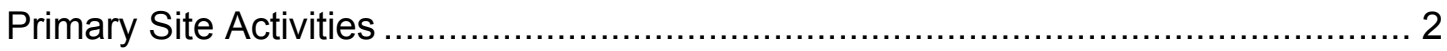

Chapter 2 Environmental Management System ........................................ 7

Environmental Management System Policy ........................................................ 7

Chapter 3 Environmental Compliance......................................................17

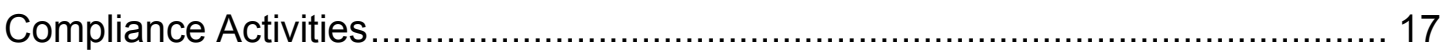

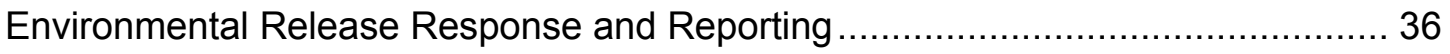

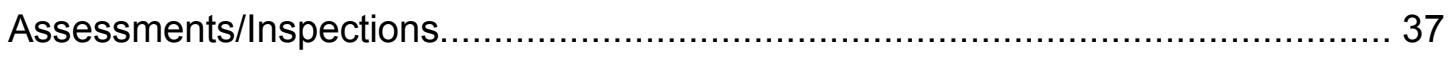

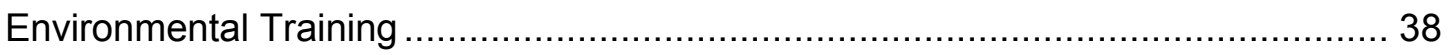

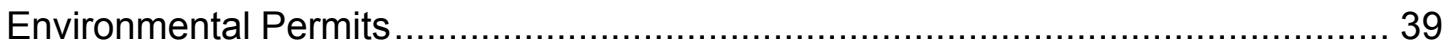

Chapter 4 Effluent Monitoring .................................................................

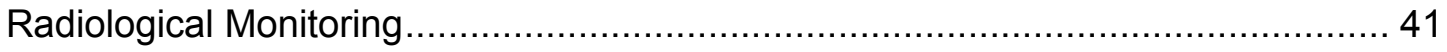

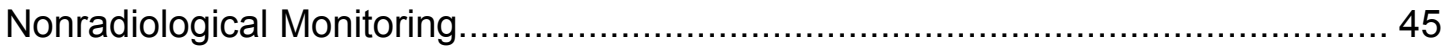

Chapter 5 Environmental Surveillance ......................................................

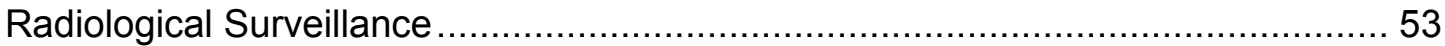

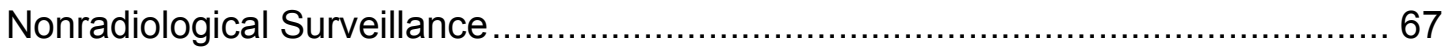

Chapter 6 Potential Radiation Doses.........................................................

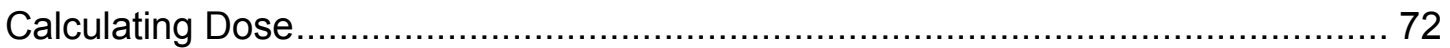

Dose Calculation Results ........................................................................ 73 


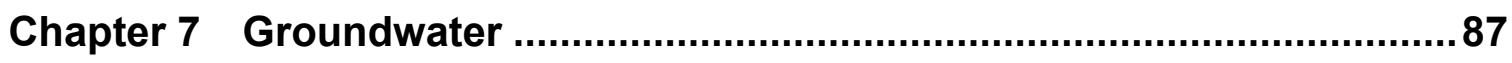

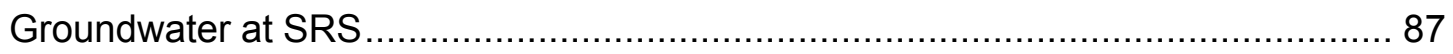

Groundwater Protection Program at SRS .................................................... 91

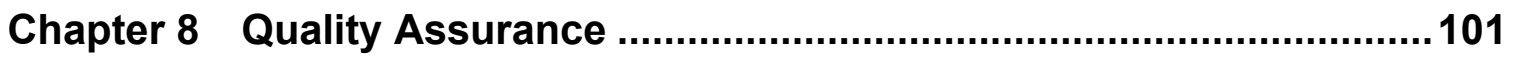

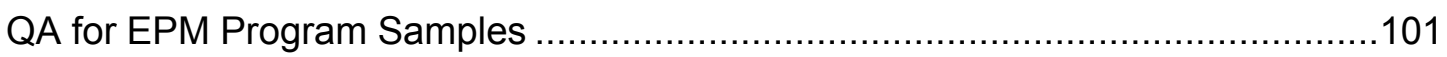

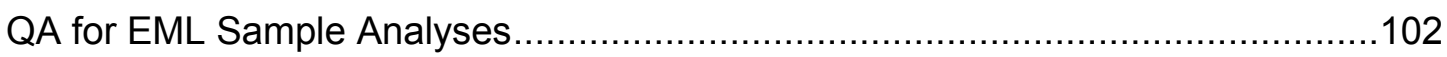

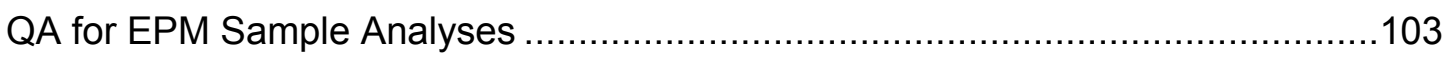

Appendix A Applicable Guidelines, Standards, and Regulations............ 109

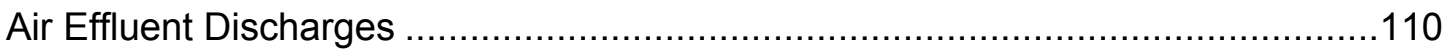

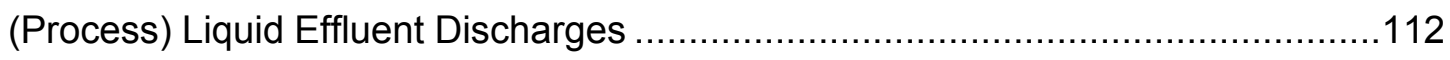

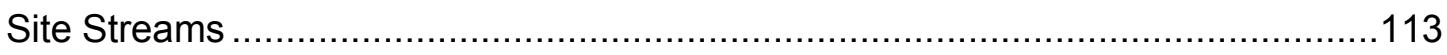

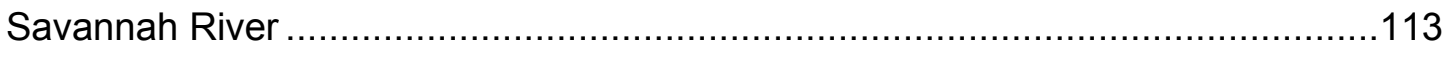

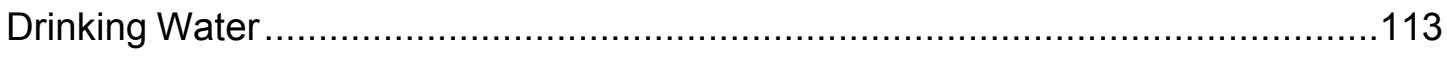

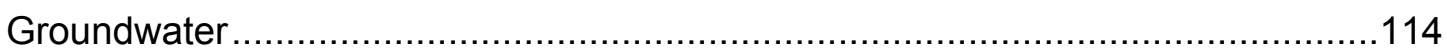

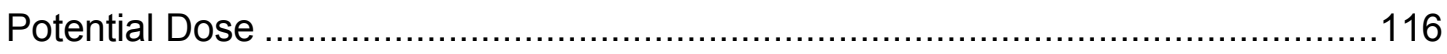

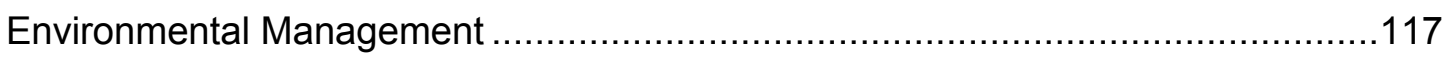

Quality Assurance/Quality Control ...............................................................

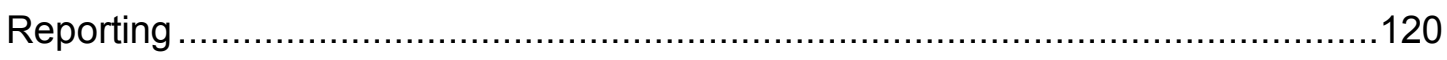

Appendix B Radionuclide and Chemical Nomenclature .........................121

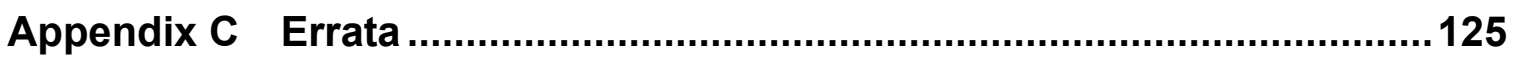

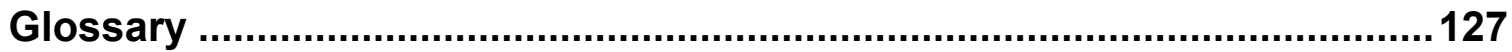

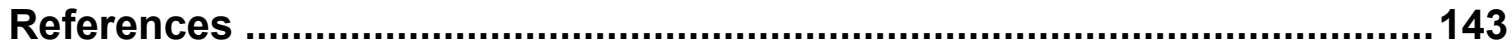




\section{List of Figures}

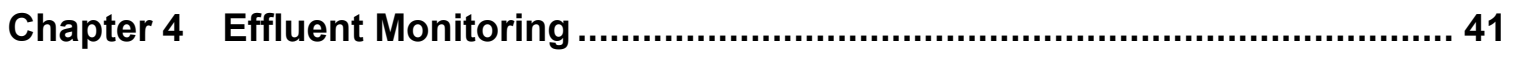

Figure 4-1 Ten-Year History of SRS Annual Atmospheric Tritium Releases ........ 43

Figure 4-2 Ten-Year History of Direct Releases of Tritium to SRS Streams......... 45

Chapter 5 Environmental Surveillance ...................................................53

Figure 5-1 Tritium from SRS Seepage Basins and SWDF to Site Streams,

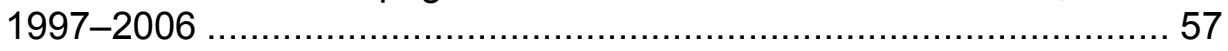

Figure 5-2 SRS Tritium Transport Summary, 1960-2006 ………………......... 60

Chapter 6 Potential Radiation Doses.......................................................71

Figure 6-1 Ten-Year History of SRS Maximum Potential All-Pathway Doses....... 80

Figure 6-2 Ten-Year History of SRS Creek Mouth Fisherman's Dose.................. 84

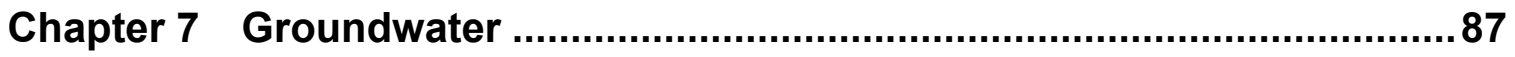

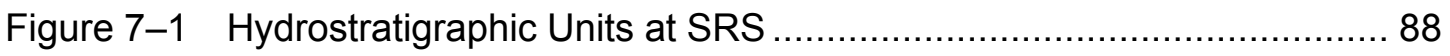

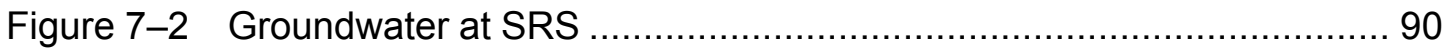

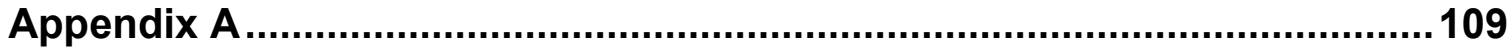

Figure A-1 SRS EM Program QA Document Hierarchy …................................119 



\section{List of Tables}

Chapter 3 Environmental Compliance ......................................................17

Table 3-1 Some Key Regulations With Which SRS Must Comply $\ldots \ldots \ldots \ldots \ldots \ldots \ldots \ldots \ldots \ldots$

Table 3-2 SRS Reporting Compliance with Executive Order 12856.................. 23

Table 3-3 Summary of NEPA Activities at SRS During 2005 ........................... 24

Table 3-4 SRS Construction and Operating Permits, 2002-2006 ...................... 39

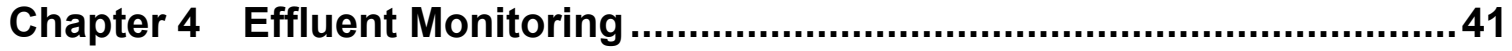

Table 4-1 2005 SRS Estimated Criteria Pollutant Air Emissions ........................ 47

Table 4-2 SRS Power Plant Boiler Capacities .............................................. 48

Table 4-3 Boiler Stack Test Results...................................................... 48

Table 4-4 2006 Exceedances of SCDHEC-Issued NPDES Permit Liquid Discharge Limits at SRS ......................................................... 51

Chapter 6 Potential Radiation Doses...................................................71

Table 6-1 2006 Radioactive Liquid Release Source Term and 12-Month Average Downriver Radionuclide Concentrations Compared to EPA's Drinking Water Maximum Contaminant Levels (MCLs)

Table 6-2 Potential Dose to the Maximally Exposed Individual from SRS Liquid Releases in 2006

Table 6-3 Potential Dose to the Maximally Exposed Individual from SRS Atmospheric Releases in 2006

Table 6-4 2006 Maximum Potential All-Pathway and Sportsman Doses

Compared to the DOE All-Pathway Dose Standard

Table 6-5 Potential Lifetime Risks from the Consumption of Savannah

River Fish Compared to Dose Standards.

Chapter 7 Groundwater

Table 7-1 Summary of Maximum Groundwater Monitoring Results for Major Areas Within SRS, 2005-2006

Chapter 8 Quality Assurance

Table 8-1 EML Performance on Mixed Analyte Performance Evaluation Program (MAPEP)....

Table 8-2 Subcontract-Laboratory Performance Environmental Resource Associates (ERA) Water Pollution Studies 
Table 8-3 Subcontract-Laboratory Performance on Mixed-Analyte

Performance Evaluation Program (MAPEP) .107

\section{Appendix A}

Table A-1 Criteria Air Pollutants .................................................................. 111

Table A-2 Airborne Emission Limits for SRS Coal-Fired Boilers .......................112

Table A-3 Airborne Emission Limits for SRS Fuel Oil-Fired Package Boilers .....112

Table A-4 South Carolina Water Quality Standards for Freshwaters. .114 


\section{Sampling Location Information}
Note: $\quad$ This section contains sampling location abbreviations used in the text and/or on the sampling location maps. It also contains a list of sampling locations known by more than one name (see next page).

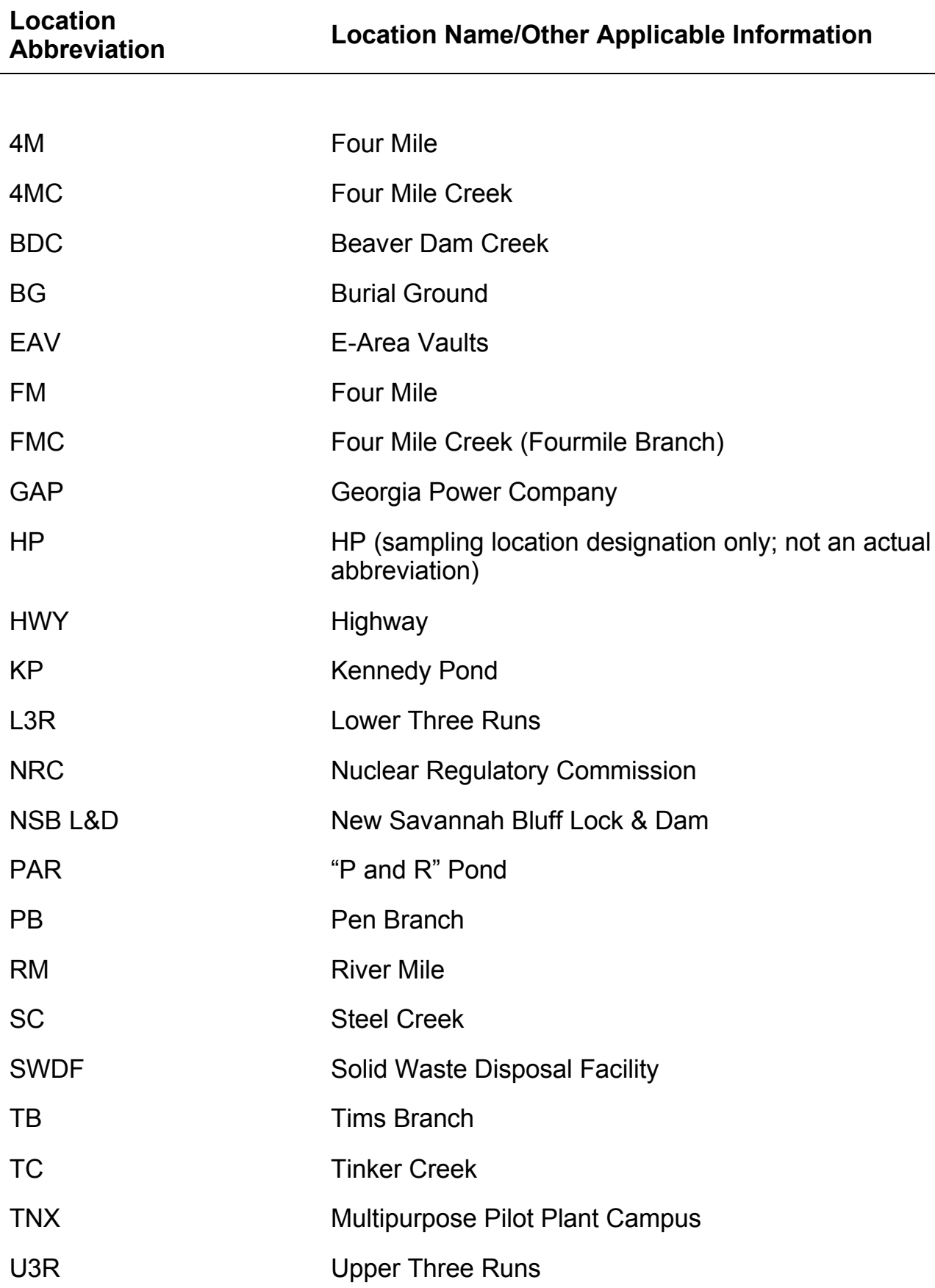

$4 \mathrm{M}$

$4 \mathrm{MC}$

$\mathrm{BDC}$

BG

EAV

FM

FMC

GAP

$\mathrm{HP}$

HWY

$\mathrm{KP}$

L3R

NRC

NSB L\&D

PAR

PB

RM

SC

SWDF

TB

TC

TNX

U3R

Four Mile

Four Mile Creek

Beaver Dam Creek

Burial Ground

E-Area Vaults

Four Mile

Four Mile Creek (Fourmile Branch)

Georgia Power Company

HP (sampling location designation only; not an actual abbreviation)

Highway

Kennedy Pond

Lower Three Runs

Nuclear Regulatory Commission

New Savannah Bluff Lock \& Dam

"P and R" Pond

Pen Branch

River Mile

Steel Creek

Solid Waste Disposal Facility

Tims Branch

Tinker Creek

Multipurpose Pilot Plant Campus

Upper Three Runs 


\section{Sampling Locations Known by More Than One Name}

Augusta Lock and Dam; New Savannah Bluff Lock and Dam

Beaver Dam Creek; 400-D

Four Mile Creek-2B; Four Mile Creek at Road C

Lower Three Runs-2; Lower Three Runs at Patterson Mill Road

Pen Branch-3; Pen Branch at Road A-13-2

R-Area downstream of $\mathrm{R}-1 ; 100-\mathrm{R}$

River Mile 118.8; U.S. Highway 301 Bridge Area; Highway 301; US 301

River Mile 129.1; Lower Three Runs Mouth

River Mile 141.5; Steel Creek Boat Ramp

River Mile 150.4; Vogtle Discharge

River Mile 152.1; Beaver Dam Creek Mouth

River Mile 157.2; Upper Three Runs Mouth

River Mile 160.0; Dernier Landing

Steel Creek at Road A; Steel Creek-4; Steel Creek-4 at Road A; Steel Creek at Highway 125

Tims Branch at Road C; Tims Branch-5

Tinker Creek at Kennedy Pond; Tinker Creek-1

Upper Three Runs-4; Upper Three Runs-4 at Road A; Upper Three Runs at Road A; Upper Three Runs at Road 125

Upper Three Runs-1A; Upper Three Runs-1A at Road 8-1 


\section{Executive Summary}

7 he Savannah River Site Environmental Report for 2006 (WSRC-TR-2007-00008) is prepared for the U.S. Department of Energy (DOE) according to requirements of

1 DOE Order 231.1A, "Environment, Safety and Health Reporting," and DOE Order 5400.5, "Radiation Protection of the Public and Environment." The report's purpose is to

- present summary environmental data that characterize site environmental management performance

- confirm compliance with environmental standards and requirements

- highlight significant programs and efforts

- assess the impact of SRS operations on the public and the environment

\section{Minimal Impact}

SRS posted another strong environmental compliance record in 2006, as its operations continued to result in minimal impact to the offsite public and the surrounding environment. The site's radioactive and chemical discharges to air and water were well below regulatory maximums for environmental and public health protection; its air and water quality met appropriate requirements; and the radiation dose from its discharges was smaller than natural background doses or safety-based dose standards.

The largest radiation dose that an offsite, hypothetical, maximally exposed individual could have received from SRS operations during 2006 was estimated to be 0.20 millirem- 0.11 millirem from the airborne pathways plus 0.09 millirem from the liquid pathway. (A millirem is a standard unit of measure for radiation exposure.) The 2006 SRS dose is just 0.20 percent of the DOE all-pathway dose standard of 100 millirem per year, and far less than the natural average dose of about 300 millirem per year to people in the United States. The 2006 dose is more than the 2005 all-pathway dose of 0.13 millirem because of greater estimated diffuse and fugitive releases of unspecified alpha- and beta-emitters-primarily from a specific remediation project, General Separations Area Consolidated Unit. Because this project was completed in 2006, its source term will not be a factor in future dose calculations. By definition, diffuse and fugitive releases cannot be measured but are conservatively estimated based on the inventory of residual radionuclides in waste sites being remediated.

\section{Extensive Monitoring; Documented Compliance}

Environmental monitoring is conducted extensively within a 2,000-square-mile network extending 25 miles from SRS, with some monitoring performed as far as 100 miles from the site. The area includes neighboring cities, towns, and counties in Georgia and South Carolina. Thousands of samples of air, rainwater, surface water, drinking water, groundwater, food products, wildlife, soil, sediment, and vegetation are collected by SRS 
and state authorities and analyzed for the presence of radioactive and nonradioactive contaminants.

Compliance with environmental regulations and with DOE orders related to environmental protection provides assurance that onsite processes do not impact the public or the environment adversely. Such compliance is documented in this report.

SRS had a National Pollutant Discharge Elimination System (NPDES) compliance rate of 99.94 percent in 2006 - only slightly lower than the 99.97 percent rate reported in 2005. The NPDES program protects streams, reservoirs, and other wetlands by limiting the release of nonradiological pollution into surface waters. Discharge limits are set for each facility to ensure that SRS operations do not negatively impact aquatic life or degrade water quality.

\section{Two Notices of Violation}

After a 20-month run of operations with no notices of violation (NOVs) from SCDHEC, SRS received two NOVs in 2006 - both under the Clean Water Act. The first was received June 6 for the March 2 and March 10 exceedances of the monthly average and daily maximum limits for ammonia at the site's NPDES Outfall G-10. Because SRS reported and explained the exceedances in its March Discharge Monitoring Report (DMR), no formal response to the NOV was required, and no fines or penalties were issued. The site took steps to prevent recurrence of the ammonia exceedances, and sample analyses conducted since implementation of the corrective actions have shown the $\mathrm{G}-10$ outfall to be within permit compliance.

The second NOV was received November 2 for exceeding the August monthly average discharge limit for lead at NPDES Outfall F-08. Because the site reported this exceedance in its August DMR, no formal response was required, and no fines or penalties were issued. The issue was addressed by rerouting flows and taking offline certain equipment/piping that had been restarted and was causing the lead exceedance.

\section{Wide Distribution}

SRS environmental reports have been produced for more than 50 years. Copies are distributed to government officials, universities, public libraries, environmental and civic groups, news media, and interested individuals. 


\title{
Introduction
}

\author{
Pete Fledderman and Al Mamatey \\ Environmental Services Section
}

$\mathrm{T}$ The Savannah River Site (SRS), one of the facilities in the U.S. Department of Energy (DOE) complex, was constructed during the early 1950s to produce materials (such as plutonium-239 and tritium) used in nuclear weapons. The site covers approximately 310 square miles in South Carolina and borders the Savannah River.

\section{Mission}

SRS's mission is to fulfill its responsibilities safely and securely in the stewardship of the nation's nuclear weapons stockpile, nuclear materials, and the environment. These stewardship areas reflect current and future missions to

- meet the needs of the enduring U.S. nuclear weapons stockpile

- store, treat, and dispose of excess nuclear materials safely and securely

- treat and dispose of legacy wastes from the Cold War and clean up environmental contamination

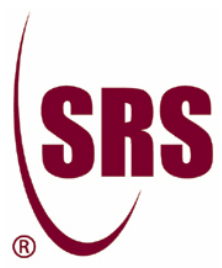

SRS will continue to improve environmental quality, clean up its legacy waste sites, and manage any waste produced from current and future operations. Managing this waste will include working with DOE, the State of South Carolina, the Environmental Protection Agency, and the Nuclear Regulatory Commission to ensure that there are safe and acceptable ways to (1) dispose of radioactive liquid waste and nuclear materials permanently off site, while grouting any remaining waste tank

residue, and (2) determine mutually acceptable solutions for waste disposition.

\section{Site Location, Demographics, and Environment}

SRS covers 198,344 acres in Aiken, Allendale, and Barnwell counties of South Carolina. The site is approximately 12 miles south of Aiken, South Carolina, and 15 miles southeast of Augusta, Georgia.

The average population density in the counties surrounding SRS is about 91 people per square mile, with the largest concentration in the Augusta metropolitan area. Based on 2000 U.S. Census Bureau data, the population within a 50-mile radius of the center of SRS is approximately 712,780 .

\section{Water Resources}

SRS is bounded on its southwestern border by the Savannah River for about 35 river miles and is approximately 160 river miles from the Atlantic Ocean. 
The Savannah River is used as a drinking water supply source for some residents in the vicinity of SRS. The nearest downriver drinking water sources are approximately 90 miles from the site. The river also is used for commercial and sport fishing, boating, and other recreational activities. There are no known large-scale uses of the river for irrigation by farming operations downriver of the site.

\section{Geology}

SRS is located on the southeastern Atlantic Coastal Plain, which is part of the larger Atlantic Plain that extends south from New Jersey to Florida. The center of SRS is approximately 25 miles southeast of the geological Fall Line that separates the Coastal Plain from the Piedmont.

\section{Land and Forest Resources}

About 90 percent of SRS land area consists of managed pine plantations or natural forests. The site contains portions of three forest types: Oak-Hickory-Pine, Southern Mixed, and Southern Floodplain.

More than 370 Carolina bays exist on SRS. These unique wetlands provide important habitat and refuge for many plants and animals.

\section{Animal and Plant Life}

The majority of SRS is undeveloped; only about 10 percent of the total land area is developed or used for industrial facilities. The remainder is maintained in healthy, diverse ecosystems. About 260 species of birds, 60 species of reptiles, 40 species of amphibians, 80 species of freshwater fish, and 50 species of mammals exist on site.

\section{Primary Site Activities}

\section{Separations}

Originally, site facilities generated materials for nuclear weapons. Since the end of the Cold War in 1991, however, use of the facilities has shifted to the stabilization of nuclear materials from onsite and offsite sources to ensure safe long-term storage or disposal.

\section{Spent Nuclear Fuel Storage}

The site's spent nuclear fuel facilities house used fuel elements from reactors.

the world by receiving, stabilizing, and dispositioning spent fuels in a safe and environmentally sound matter.
These elements were generated during site reactor operations and also come from offsite sources. The mission of the spent nuclear fuel project is to cost effectively eliminate the hazards associated with the remaining legacy of spent nuclear fuels at SRS and throughout 


\section{Tritium Processing}

SRS tritium facilities extract tritium from absorber rods received from the Tennessee Valley Authority, and recycle tritium from nuclear weapons reservoirs that have been returned from service. This allows the United States to use its tritium supplies effectively and efficiently.

\section{Waste Management}

\section{SRS manages}

- the large volumes of radiological and nonradiological waste created by previous operations of the nuclear reactors and their support facilities

- newly generated waste created by ongoing site operations

Although the primary focus is on safely managing the radioactive liquid waste, the site also must handle, store, treat, dispose of, and minimize solid waste resulting from past, ongoing, and future operations. Solid waste includes hazardous, low-level, mixed, sanitary, and transuranic wastes. More information about radioactive liquid and solid wastes is included on the CD housed inside the back cover of this report.

\section{Site Deactivation and Decommissioning}

With the declining need for a large nuclear weapons stockpile, many SRS facilities no longer produce or process nuclear materials. The facilities have become surplus and must be dispositioned safely and economically. Many of them are large and complex and contain materials that, if improperly handled or stored, could be harmful. In 2002, SRS began extensive decommissioning activities in DArea, M-Area, and T-Area (also known as TNX). Site D\&D (deactivation and decommissioning) continued extensive operations through 2006. A total of 247 facilities were removed through the end of 2006, representing a footprint reduction of 2.5 million square feet. Completion of decommissioning activities in

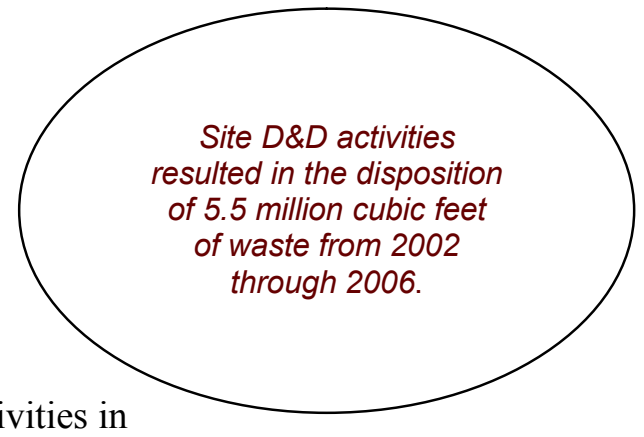
D-Area, M-Area, and TNX has allowed SRS to move forward with Area Completion activities. TNX completion was achieved in 2006, while M-Area Completion activities continued and D-Area Completion began. More information about Site D\&D activities is included on the CD housed inside the back cover of this report.

\section{Soil and Groundwater Closure Projects}

Soil and Groundwater Closure Projects (SGCP) is responsible for the remediation of 515 SRS waste units to reduce risk and protect human health and the environment. The remediation is regulated under the Comprehensive Environmental Response, Compensation, and Liability Act (CERCLA) and the Resource Conservation and Recovery Act (RCRA). This is accomplished through the SRS Federal Facility Agreement (FFA), a tri-party agreement between the U.S. Environmental Protection Agency, the South Carolina Department of Health and Environmental Control, and DOE. The FFA provides guidelines that 
- direct the comprehensive remediation of the site

- ensure that SRS satisfies RCRA and CERCLA requirements

- include cleanup schedules for SRS waste units

During 2006, SGCP personnel contributed to a number of initiatives that support the organization's cleanup strategies: (1) the Area Completion Approach, (2) the SRS FY06 Project Execution Plan, and (3) the SRS Groundwater Cleanup Program Overview for DOE-HQ. SGCP also completed more than nine years and eight millions hours without a lost workday injury.

More information about SGCP operations is included on the CD accompanying this report.

\section{Environmental Monitoring}

SRS has always been concerned about the safety of the public and on-site workers. The site is committed to protecting human health and reducing the risks associated with past, current, and future operations. Sampling locations, sample media, sampling frequency, and types of analysis are selected based on environmental regulations, exposure pathways, public concerns, and measurement capabilities.

\section{Releases}

Releases to the environment of radioactive and nonradioactive materials come from legacy contamination as well as from ongoing site operations. For instance, shallow contaminated groundwater - a legacy - flows slowly toward onsite streams and swamps and into the Savannah River. In ongoing site operations, releases occur during the processing of nuclear materials.

Meeting certain regulations, such as the Safe Drinking Water Act and the Clean Air Act, requires that releases of radioactive materials from site facilities be limited to very small fractions of the amount handled. The site follows a philosophy that emissions (discharges) will be kept far below the regulatory standards.

\section{Pathways}

The routes that contaminants can follow to get to the environment and then to people are known as exposure pathways. A person potentially can be exposed when he or she breathes the air, consumes locally produced foods and milk, drinks water from the Savannah River, eats fish caught from the river, or uses the river for recreational activities such as boating, swimming, etc.

One way to learn if contaminants from the site have reached the environment is through environmental monitoring. The site gathers thousands of air, water, soil, sediment, food, vegetation, and animal samples each year. The samples are analyzed for potential contaminants released from site operations, and the potential radiation exposure to the public is assessed. Samples are taken at the points where materials are released from the facilities (effluent monitoring) and out in the environment itself (environmental surveillance). 


\section{Research and Development}

The Savannah River National Laboratory (SRNL) - the site's applied research and development laboratory - creates, tests, and implements solutions to SRS's technological challenges. Other environmental research is conducted at SRS by the following organizations:

- Savannah River Ecology Laboratory (SREL) - More information can be obtained by contacting SREL at 803-725-0156 or by viewing the laboratory's website at http://www.uga.edu/srel. Also, SREL's technical progress report for 2006 is included on the CD accompanying this document.

- U.S. Department of Agriculture Forest Service-Savannah River (USFS - SR) - More information can be obtained by contacting USFS-SR at 803-725-0006 or 803-7250237 or by viewing the USFS-SR website at http://www.srs.gov/general/srfs/srfs.htm. Also, USFS-SR's 2006 report is included on the CD accompanying this document.

- Savannah River Archaeological Research Program (SRARP) - More information can be obtained by contacting SRARP at 803-725-3623. 



\title{
Environmental Management System
}

\author{
Benjamin C. Terry \\ Environmental Services Section
}

\begin{abstract}
A Environmental Management System (EMS) ensures that environmental issues $A$ are systematically identified, controlled, and monitored. The Savannah River Site 1 (SRS) conforms to U.S. Department of Energy-Headquarters (DOE-HQ)-directed performance metrics that demonstrate the successful implementation of an EMS at SRS.
\end{abstract}

This chapter focuses on Washington Savannah River Company's (WSRC's) integration of numerous environmental requirements mandated by existing statutes, regulations, and policies implemented through the EMS. All 14 contractor requirements mandated by DOE Order 450.1, "Environmental Protection Program," are appropriately considered in the WSRC Integrated Safety Management System (ISMS) structure. DOE-HQ, through the Office of Health, Safety, and Security Performance Assurance, concluded during its 2005 inspection of Environment, Safety, and Health Programs at SRS that "EMS has been implemented pursuant to DOE Order 450.1 and incorporated into line operations by WSRC for both environmental management and National Nuclear Security Administration functions at SRS, and the pollution prevention program is effective." The independent evaluation further concluded that "SR provides effective oversight for EMS-significant aspects by participating in contractor assessments and frequently interacting with WSRC environmental management and staff."

The latest annual WSRC Integrated Safety Management System Review, published in October 2006, concluded that the various environmental protection media areas (air, water, and waste programs, etc.) continue to meet or exceed performance expectations. The following is the text of the current EMS Policy for the site:

\section{Savannah River Site \\ Environmental Management System Policy August 2006}

\section{OBJECTIVE}

To implement sound stewardship practices that are protective of the air, water, land, and other natural and cultural resources impacted by Savannah River Site (SRS) operations. All activities on SRS shall be conducted in compliance with applicable laws and regulations providing for the protection of public health and the environment, to reduce the use of procedures and processes that produce hazardous wastes, and to seek ways to continuously improve the performance of activities protective of the environment. The objective of this policy is to establish a consistent sitewide approach to environmental protection through 
the implementation of an Environmental Management System (EMS) as part of the overall ISMS. The EMS provides for the systematic planning, integrated execution, and evaluation of Site activities for (1) public health and environmental protection, (2) pollution prevention (P2), (3) compliance with applicable environmental protection requirements and (4) continuous improvement of the EMS.

\section{DIRECTIVE}

Recognizing that many aspects of operations carried out at SRS may impact the environment, the SRS policy is that all employees, contractors, subcontractors, and other entities performing work at SRS shall abide by the directives in this document. This document serves as the primary documentation for the environmental goals and objectives of SRS and shall be available to the public. It shall be centrally maintained and updated as necessary to reflect the changing needs, mission, vision, and goals of SRS. The Department of Energy-Savannah River Operations Office (DOE-SR), Washington Savannah River Company (WSRC), Wackenhut Services Incorporated-Savannah River Site (WSI-SRS), Savannah River Ecology Laboratory (SREL), National Nuclear Security AdministrationSavannah River Site Office (NNSA-SRSO), National Nuclear Security AdministrationFissile Materials Disposition Office (NNSA-FMDO), the United States Forest ServiceSavannah River (USFS-SR), Parsons, and Duke Cogema Stone \& Webster endorse the principles stated in this policy.

The Environmental Management System pursues and measures continuous improvement in performance by establishing and maintaining documented environmental objectives and targets that correspond to SRS's mission, vision, and core values. The environmental objectives and targets shall be established for each relevant function within DOE-SR, NNSA-SRSO, NNSA-FMDO, and all contractors, subcontractors, and other entities performing work at SRS for all activities having actual or potentially significant environmental impacts.

DOE-SR, NNSA-SRSO, and NNSA-FMDO, and all contractors, subcontractors, and other entities performing work at SRS shall:

1. Manage the SRS environment, natural resources, products, waste, and contaminated materials so as to eliminate or mitigate any threat to human health or the environment at the earliest opportunity and implement process improvements, as appropriate, to ensure continuous improvement of performance in environmental management.

2. Develop policies, procedures, and training as needed to identify activities with significant environmental impacts; to manage, control, and mitigate the impacts of these activities; and to assess performance and implement corrective actions where needed.

3. Implement a pollution prevention program to reduce waste generation, releases of pollutants, future waste management and pollution control costs, and to promote energy efficiency.

4. Conduct operations in compliance with all applicable federal, state, and local laws, regulations, statutes, executive orders, directives, and standards.

5. Work cooperatively and openly with appropriate local, state, federal agencies, public stakeholders, and site employees to prevent pollution, achieve environmental compliance, conduct cleanup and restoration activities, enhance environmental quality, and ensure the protection of workers and the public. 
6. Design, develop, operate, maintain, decommission, and deactivate facilities and perform operations in a manner that shall be resource efficient and will protect and improve the quality of the environment for future generations and continue to maintain SRS as a unique national environmental asset.

7. Recognize that the responsibility for quality communications rests with each individual employee and that it shall be the responsibility of all employees to identify and communicate ideas for improving environmental protection activities and programs at the site.

8. Ensure the early identification of, and appropriate response to, potential adverse environmental impacts associated with DOE operations, including as appropriate, preoperational characterization and assessment; and effluent and surveillance monitoring.

9. Promote the long-term stewardship of SRS's natural and cultural resources throughout its operational, closure, and post-closure life cycle.

Adherence to and programmatic implementation of this policy shall be the responsibility of the DOE-SR, NNSA-SRSO, and NNSA-FMDO managers in coordination with the contractors, subcontractors, and other entities performing work at SRS.

Original document signed by the following:

Jeffrey M. Allison, Manager

Savannah River Operations Office

Richard W. Arkin, Manager

Savannah River Site Office

Wackenhut Services Incorporated-SRS

Keith Lawrence, Forest Manager

USDA Forest Service-Savannah River

David Stinson, President

Duke Cogema Stone \& Webster
Robert A. Pedde, President

Washington Savannah River Company, LLC

Charles H. Terhune, III,

Sr. Vice President and Project Manager

Parsons

Dr. Paul M. Bertsch, Director

Savannah River Ecology Laboratory

James H. Isom, Sr. Vice President and General Manager NNSA

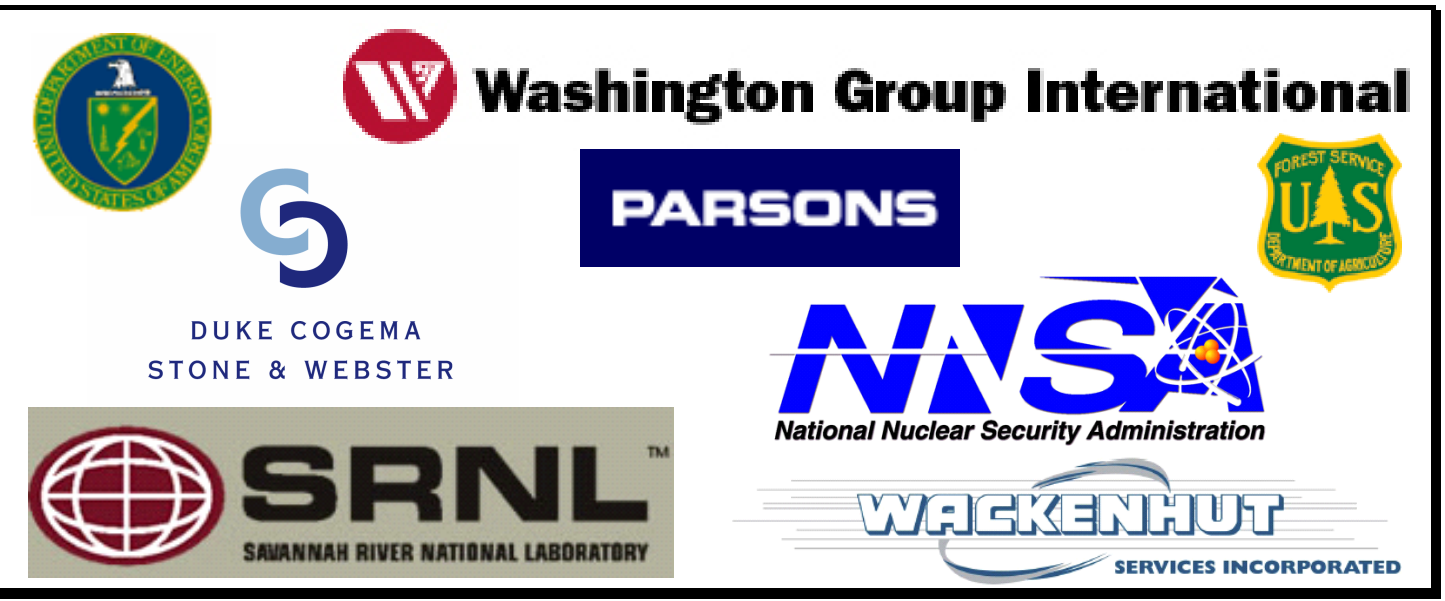




\section{SRS EMS Implementation}

The International Organization for Standardization (ISO) 14001 Standard, Environmental Management System, defines the structure for implementing EMS and improving environmental performance. The process-based structure of the ISO 14001 Standard is based on the "Plan-Do-Check-Act" improvement cycle. The standard requires an organization to develop an implement the policy, implement corrective actions, and review the adequacy and effectiveness. follows the guidelines of ISO certified. The SRS EMS was

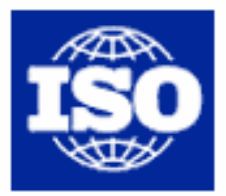
environmental policy, create plans to the plans, check progress and take system annually to ensure its Although the SRS EMS program 14001 , the program no longer is designed to meet the rigorous requirements of the globally recognized (ISO) 14001 Environmental Management Standard, with additional emphasis on public health and regulatory compliance, pollution prevention, and continuous improvement. The following paragraphs describe the 17 elements that demonstrate SRS implementation of the ISO 14001 Standard:

\section{Environmental Policy}

The SRS EMS Policy is a statement of the site's intention to implement sound stewardship practices that are protective of the air, water, land, and other natural cultural resources impacted by SRS operations. All SRS activities shall be conducted to comply with applicable laws and regulations providing for the protection of public health and the environment, to reduce the use of procedures and processes that produce hazardous wastes, and to seek ways to continuously improve the performance of activities protective of the environment. The objective of this policy is to establish a consistent sitewide approach to environmental protection through the implementation of an EMS as part of the overall ISMS. The EMS provides for the systematic planning, integrated execution, and evaluation of site activities for (1) public health and environmental protection, (2) pollution prevention (P2), (3) compliance with applicable environmental protection requirements, and (4) continuous improvement of the EMS.

\section{Environmental Aspects and Impacts}

Determining environmental aspects (elements of activities, products, processes, and services that could have a significant impact on the environment) is critical to the EMS process. It equates to analyzing hazards in ISMS discussions. Identifying the SRS environmental aspects is not the end of the process. Work activities, whether routine or unusual, must consider whether these aspects are a potential part of the work activity. This leads to the development and implementation of controls necessary to mitigate the potential that the action will adversely affect the environment. SRS has determined that the following aspects of its operations have the potential to affect the environment:

- radionuclides

- high-level waste

- transuranic (TRU) waste

- pollution prevention

- energy and water use

- environmental restoration
- nuclear material

- low-level waste

- mixed waste

- chemical commodities

- natural resources

- ecological research 
- development, demonstration, and deployment

- solid waste (hazardous, nonhazardous, sanitary, nonradioactive)
- environmental remediation

- deactivation and demolition

- cultural/historical resources

\section{Legal and Other Requirements}

Regulatory and DOE requirements for environmental programs are included in the WSRC Standards/Requirements Identification Document(S/RID), Functional Area 20. The purpose of the S/RID is to address environmental, safety, and health requirements related to environmental protection activities undertaken by WSRC on behalf of DOE at SRS. The source includes DOE Order 5400.5, DOE Order 450.1, and other directives. The environmental protection S/RID functional area includes activities required to protect the environment and the health of the public and workers. This S/RID covers the technical and programmatic requirements from applicable standards, laws, and regulations.

\section{Objectives, Targets, and Programs}

The EMS pursues and measures continual improvement in performance by establishing and maintaining documented environmental objectives and targets that counterbalance SRS activities having actual or potentially significant environmental impacts. Objectives and targets are established to 1) achieve full compliance with applicable environmental requirements, 2) devote resources to specific pollution prevention initiatives, and 3) ensure responsible stewardship of natural and historical resources at SRS. The SRS goals and objectives are described in the following document references:

Environmental Restoration Management Action Plan (MAP) - The SRS MAP “integrates environmental restoration activities at SRS with operational activities and allows meaningful comparison against restoration programs complexwide. The MAP's purpose is to describe the status of the program to identify environmental restoration goals, strategies, and initiatives. The SRS MAP serves as the management framework for environmental restoration activities, stakeholder requirements and recommendations, and missionoriented activities."

Waste Minimization and Pollution Prevention Plan (WMin/P2) - This plan is a high-level "umbrella" document for the overall WSRC pollution prevention program. Many pollution prevention initiatives are guided by program-specific plans, goals, and objectives. Facility/Project pollution prevention implementation plans support this company level plan.

Natural Resources Management Plan (NRMP) - The USFS-SR uses the NRMP to provide strategic guidance for SRS natural resource programs, and furthers the mission of SRS by helping to ensure responsible stewardship of the environmental resources at SRS.

Savannah River Archeological Research Program (SRARP) - The SRARP describes how technical expertise is employed to help DOE-SR meet federal and state regulatory requirements for the identification, evaluation, and protection of archeological and historic sites and artifacts at SRS. 
Natural Resource Management Operations Plans (NRMOP) - The USFS-SR develops NRMOPs to fulfill the requirements of the NRMP and to provide more detailed guidance for developing and managing natural resource programs and research projects.

USFS-SR Management Implementation Plan (MIP) - This document contains implementing actions derived from the Savannah River Strategic Plan, the NRMP and the USFS-SR NRMOPs. It includes performance measures for activities delineated by the documents listed above from the USFS-SR Annual Work Plan.

WSI-SRS Annual Operational Plan (AOP) - The AOP identifies each task to be performed by WSI-SRS with respect to major operations or programs defined by DOE-SR.

\section{Resources, Roles, Responsibilities, and Authorities}

All WSRC employees have specific roles and responsibilities in key areas, including environmental protection. Environmental and waste management technical support personnel assist site line organizations with developing and meeting their environmental responsibilities.

\section{Competence, Training, and Awareness}

The purpose of SRS environmental training programs is to ensure that personnel whose actions could have environmental consequences are properly trained and made aware of their responsibilities to protect the environment, workers, and the public. EMS requirements have been provided to employees whose responsibilities include environmental protection and regulatory compliance. EMS awareness training is included within the General Employee Training Program for visitors and subcontractors. Additionally, all site employees are required to complete Consolidated Annual Training each year.

\section{Communication}

SRS continues to improve internal and external communications on environmental issues. Many policies and procedures guide communications at SRS, ranging from the general site policy to forms and techniques addressed in facility-specific procedures. Additionally, WSRC solicits input from interested parties such as community members, activists, elected officials, and regulators - primarily through the SRS Citizens Advisory Board. At the core of the communication and community involvement programs are the SRS EMS Policy and the SRS Federal Facility Agreement Community Involvement Plan.

\section{Documentation}

The following sources document ways that various SRS organizations describe or manage their environmental management systems:

- $\quad$ SRS EMS Manual, G-TM-G-0001

- SRM 300.1.1B, Human Resources Management Manual

- SREL Environmental Management Program Description

- WSI-SR Environmental Management System Implementation Plan, WSI 1-05

- USFS-SR Natural Resource Management Operations Plans 


\section{Control of Documents}

Environmental documents are part of the site document control system. Any document that relates to an environmental activity is controlled by the appropriate system.

\section{Operational Control}

The operational control element of the EMS is intended to ensure that operational controls are in place to carry out the environmental policy-related activities of regulatory compliance, pollution prevention, and continuous improvement by SRS management. The Assisted Hazards Analysis process and Environmental Evaluation Checklists (EECs) are vital components of this program.

\section{Emergency Preparedness and Response}

SRS emergency plans and programs include occurrences categorized as environmental emergencies. Procedures that guide the Emergency Preparedness Process are referenced below.

- WSRC 1-01 ("Management Policies"), 4.12, Emergency Preparedness

- WSRC SCD-7, Savannah River Site Emergency Plan (includes drills and exercises)

- WSRC 9B, Site Item Reportability and Issue Management (SIRIM)

- Central Services Works Engineering Spill Response Team procedures

- USFS-SR Emergency Response Plan and Emergency Spill Procedure

- WSI-SRS Procedure 1-6816, Emergency Management Plan

- Interface Protocol Document with Memorandums of Understanding and Security and Support Services Agreements at the Savannah River Site, Westinghouse Savannah River Company (WSRC) and Wackenhut Services, Incorporated (WSI-SRS), April 2001 - provides for emergency preparedness and response coordination between WSRC and WSI-SRS

- SREL Safety Manual, Chapter 2, Medical and Emergency Procedures and SREL Occurrence Reporting Procedures (EHS-94-0001)

\section{Monitoring and Measurement}

Monitoring and measurement means that the key characteristics of SRS operations are monitored regularly. This includes effluent monitoring (radiological and nonradiological), compliance monitoring, performance monitoring, and equipment/facility monitoring (e.g., calibration of instruments). References include the following:

\section{Effluent Monitoring}

- SRS Environmental Monitoring Plan

- WSRC-3Q1-2 (Plans and Procedures), Vol. 1, Section 1100, SRS Environmental Monitoring Program

- WSRC-ESH-EMS-94-0129 (SRS EM Corrective Action Plan)

- Environmental Geochemistry Group Operating Handbook, July 1996

- Compliance Monitoring - DOE-SR Technical Assessment Program

- USFS-SR Self-Assessments

- USFS-SR Monitoring Plans

- USFS-SR Post-Burn Evaluations 
- USFS-SR Biological Evaluations

- WSRC SCD-4, Assessment Performance Objectives and Criteria

- WSRC 3Q, Environmental Compliance

- WSRC Comprehensive Monitoring Evaluation (regulatory annual inspection) Program

\section{Equipment/Facility Monitoring}

- WSRC 1Q (Quality Assurance), 12.1,Control of Measuring and Test Equipment

- WSRC 1Q, 12.2, Control of Installed Process Instrumentation

\section{Performance Monitoring and Measurement}

- Annual SRS Environmental Report

- USFS-SR Accomplishment Reports

- Individual Agency and Divisional Performance Indicators

- WSRC 1Q, 15.1, Nonconformance Reports

- WSRC 1-01, 5.35, Corrective Action Program

- WSI-SRS Consolidated Assessment Schedule

\section{Evaluation of Compliance}

Specific environmental legislation and regulations are evaluated and assessed on a program- or facility-specific basis. SRS has established a documented procedure for periodically evaluating its compliance with relevant environmental regulations. This procedure often is integrated into an organization's environmental, safety, and health inspection process, which is performed in a prioritized fashion by a team of experts, including one on environmental regulatory issues. Periodically, environmental support organizations conduct regulatory assessments in particular topical areas to verify the compliance status of multiple organizations throughout SRS. Finally, external regulatory agencies and/or technical experts may conduct independent audits of compliance.

\section{Nonconformance; Corrective and Preventive Actions}

Nonconformance and corrective and preventive actions include EMS nonconformance as a part of the site's QA program. The application of QA procedures, therefore, supports the total EMS. For example, use of the nonconformance report form applies to environmentrelated equipment, instruments, facilities, and procedures. Also, "nonconformance" with assessments and evaluations is recorded and dispositioned according to established procedures, utilizing the following resources:

- WSRC Quality Assurance Management Plan

- DOE Technical Assessment Program Corrective Actions

- Comprehensive Monitoring Evaluation (Regulations)

- WSRC 1-01, 5.35, Corrective Action Program

- WSRC 12Q (Assessment Manual), FEB-1, Facility Evaluation Board

- WSRC 1Q

- WSI-SRS Procedure 1-3700, Improvement/Corrective Action Management Program

- USFS-SR Handbook, 6903.11, Contract Administration

- Evaluation and Cleanup of SREL Research Sites (A-98-0002) 
- Savannah River Ecology Laboratory Environmental Evaluation Procedure (A-930011)

- US GSA SRS EMS Description Document

\section{Control of Records}

The identification, maintenance, and disposition of environmental records are required by the SRS EMS. The site's records management program incorporates environmental records for these purposes. Specific documentation for programmatic environmental activities is addressed in department-level procedures. For example, the Environmental Services Section (ESS) maintains records of correspondence with regulatory agencies.

Environmental training records are maintained by the line organization requiring and conducting the training. EECs completed by facilities for specific activities are forwarded to and maintained by ESS, according to the following documents:

- DOE Order 1324.5A, Records Management Program

- WSRC 1Q, 17, Records

- WSRC 1B (Management Requirements and Procedures), 3.11, WSRC Document and Correspondence Numbering System

- WSRC 1B, 3.31, Records Management

- WSRC 1B, 3.32, Document Control

- WSRC IM-93-0060, Sitewide Records Inventory and Disposition Schedule (RIDS), Section IV: Environmental

- $\quad$ SRIP 200, Chapter 241.1, Records Management Programs

- WSI-SRS Procedure 1-1507, Records Management Requirements

- USFS-SR Handbook, 6209.11, Records Management

- ESH 94-0033, SREL Environmental Management Plan

\section{Internal Audits}

SRS audits are incorporated into the DOE assessment and WSRC self-assessment programs to verify that the site's EMS is functioning as intended. WSRC utilizes a Facility Evaluation Board to conduct independent performance-based assessments of site programs to satisfy contractual and regulatory obligations. The EMS component is evaluated alongside other site programs through a random selection process.

\section{Management Review}

The SRS EMS Policy requires periodic evaluations of the effectiveness of the EMS. The DOE-SR Office of Environment, Safety, and Health is responsible for ensuring that the evaluation is performed. Guidelines are intended to keep the management review focused on continuous improvement. Oversight of SRS's annual EMS review is the responsibility of DOE-SR's Environmental Quality Management Division. 



\section{Environmental Compliance}

Vivian Cato

Environmental Services Section

I $t$ is the policy of the U.S. Department of Energy (DOE) that all activities at the Savannah River Site (SRS) be carried out in full compliance with applicable federal, state, and local environmental laws and regulations, and with DOE orders, notices, directives, policies, and guidance. Compliance with environmental regulations and with DOE orders related to environmental protection is a critical part of the operations at SRS. The purpose of this chapter is to report on the status of SRS compliance with these various statutes and programmatic documents. Some key regulations with which SRS must comply, and the compliance status of each, are listed in table 3-1.

This chapter also will provide information on Notices of Violation (NOVs) issued by the U.S. Environmental Protection Agency (EPA) or the South Carolina Department of Health and Environmental Control (SCDHEC). NOVs are the regulatory tool used to inform organizations when their activities do not meet expected requirements. These can include NOVs against the organization's permitted activities or against the general contents of environmental regulations, such as failing to obtain construction permits prior to construction of new air release sources.

\section{Compliance Activities}

\section{Resource Conservation and Recovery Act}

The Resource Conservation and Recovery Act (RCRA) was passed in 1976 to address solid and hazardous waste management. The law requires that EPA regulate the management of solid and hazardous wastes, such as spent solvents, batteries, and many other discarded substances potentially harmful to human health and the environment. Amendments to RCRA regulate nonhazardous solid waste and some underground storage tanks.

Hazardous waste generators, including SRS, must follow specific requirements for handling these wastes. SRS received no RCRA-related NOVs during 2006.

\section{Land Disposal Restrictions}

The 1984 RCRA amendments established Land Disposal Restrictions (LDRs) to minimize the threat of hazardous constituents migrating to groundwater sources. The same restrictions apply to mixed (hazardous and radioactive) waste.

Treatability variances are an option available to waste generation facilities if alternate treatment methods are appropriate for specific waste streams. SRS has identified two mixed waste streams remaining to be treated that are candidates for treatability variances. 
Table 3-1

Some Key Regulations With Which SRS Must Comply

\begin{tabular}{lll}
\hline Legislation & What It Requires & $\begin{array}{c}\text { Compliance } \\
\text { Status }\end{array}$ \\
\hline $\begin{array}{l}\text { RCRA } \\
\text { Resource Conservation and } \\
\text { Recovery Act }\end{array}$ & $\begin{array}{l}\text { The management of hazardous and } \\
\text { nonhazardous wastes and of underground } \\
\text { storage tanks containing hazardous } \\
\text { substances and petroleum products }\end{array}$ & In compliance \\
FFCAct & $\begin{array}{l}\text { The development by DOE of schedules for } \\
\text { mixed waste treatment to meet LDR } \\
\text { requirements }\end{array}$ & In compliance
\end{tabular}

CERCLA; SARA

Comprehensive Environmental Response, Compensation, and Liability Act (1980); Superfund Amendments and Reauthorization Act (1986)

CERCLA/Title III (EPCRA) Emergency Planning and Community Right-to-Know Act (1986)

NEPA

National Environmental Policy Act (1969)

SDWA

Safe Drinking Water Act (1974)

CWA; NPDES

Clean Water Act (1977); National Pollutant Discharge Elimination System

CAA; NESHAP Clean Air Act (1970); National Emission Standards for Hazardous Air Pollutants

TSCA

Toxic Substances Control Act (1976)
The establishment of liability compensation, cleanup, and emergency response for hazardous substances released to the environment

The reporting of hazardous substances used on site (and their releases) to EPA, state, and local planning units

The evaluation of the potential environmental impact of federal activities and alternatives

The protection of public drinking water systems

In compliance

In compliance

The regulation of liquid discharges at outfalls (e.g., drains or pipes) that carry effluents to streams

The establishment of air quality standards for criteria pollutants, such as sulfur dioxide and particulate matter, and hazardous air emissions, such as radionuclides and benzene

The regulation of PCB use and disposal
In compliance

In compliance

In compliance

In compliance
In compliance

Because of special problems associated with radioactive components, these variances have been completed and sent to EPA, where they continue to await approval.

\section{Federal Facility Compliance Act}

The Federal Facility Compliance Act (FFCAct) was signed into law in October 1992 as an amendment to the Solid Waste Disposal Act to add provisions concerning the application of certain requirements and sanctions to federal facilities. A Site Treatment Plan (STP) consent order (95-22-HW, as amended) was obtained and implemented in 1995, as required by the FFCAct. A Statement of Mutual Understanding (SMU) for Cleanup Credits was executed in October 2003. The SMU allows SRS to earn credits for certain accelerated cleanup actions. Credits then can be applied to the STP commitments. SRS submitted to SCDHEC an annual update to the approved STP in November 2006 that identified changes 
in mixed waste treatment and inventory. Changes in the 2006 update include reclassifying Waste Stream SR-W009 (silver-coated packing material) as transuranic (TRU) waste, updating the commitment summary for the new fiscal year, listing the new treatment determination for Waste Stream SR-W091 (contaminated debris), eliminating Waste Stream SR-W080 (Charleston Naval Shipyard waste) and updating the Current Cumulative Inventory. SRS continued to make shipments of TRU waste to the Waste Isolation Pilot Plant (WIPP) near Carlsbad, New Mexico, and has processed additional radioactive liquid waste through the Defense Waste Processing Facility. The site also has shipped mixed waste to offsite vendors for treatment. STP updates will continue to be produced annually unless provisions of the consent order are modified.

\section{Underground Storage Tanks}

The 19 underground storage tanks at SRS that house petroleum products and hazardous substances, as defined by the Comprehensive Environmental Response, Compensation, and Liability Act (CERCLA), are regulated under Subtitle I of RCRA. These tanks require a compliance certificate annually from SCDHEC to continue operations. SCDHEC conducts an annual compliance inspection and records audit prior to issuing the compliance certificate. SCDHEC's 2006 inspection and audit found all 19 tanks to be in compliance.

\section{Liquid Radioactive Waste Tank Closure}

The primary regulatory goal of SRS's waste tank closure process at the F-Area and H-Area liquid radioactive waste tank farms is to close the tank systems in a way that protects public health and the environment in accordance with SCDHEC's Regulation 61-82, "Proper Closeout of Wastewater Treatment Facilities."

Two waste storage tanks ( $17 \mathrm{~F}$ and $20 \mathrm{~F})$ were closed in 1997 . Waste heel removal was completed in 2003 for tanks $18 \mathrm{~F}$ and $19 \mathrm{~F}$ and the evaporator system. The residual material for these facilities has been sampled and characterized. Tanks $18 \mathrm{~F}$ and $19 \mathrm{~F}$ have been isolated, and require only administrative safety basis controls; however, the next action for these two tanks will depend on the outcome from testing of a new technology to determine if additional residual material can be removed safely from these two tanks. If the testing is successful, then the technology potentially can be utilized to remove portions of the remaining residual materials in these tanks.

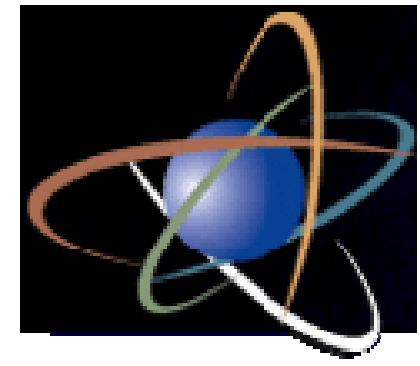

Following evaluation and implementation of the proposed technology, a waste determination in accordance with Section 3116 of the Ronald W. Reagan National Defense Authorization Act of Fiscal Year 2005 (NDAA) will be completed prior to grouting and operational closure. The NDAA authorizes the Secretary of Energy, in consultation with the Nuclear Regulatory Commission (NRC), to determine that certain waste from reprocessing activities can be managed and disposed as low-level radioactive waste and not as high-level radioactive waste. This determination also requires state approval of the F Tank Farm Closure Plan and Closure Module for the specific tanks.

DOE had begun preparation in late 2004 of the Section 3116 documentation entitled "Draft Section 3116 Determination for Closure of Tank 19 and Tank 18 at the Savannah River Site." This draft was submitted to the NRC in 2005. DOE, the NRC, the State of South 
Carolina, and the public continue to discuss tank closure determination issues, such as the evaluation of new technology for removal of additional residual waste, and the development of a new F Tank Farm Performance Assessment that would support closure of tanks $18 \mathrm{~F}$ and $19 \mathrm{~F}$, as well as additional tanks in $\mathrm{F}$ Tank Farm.

Activities also are under way regarding revisions of the General Closure Plan and Tank Closure Modules to support closure of tanks $18 \mathrm{~F}$ and 19F, consistent with the legislation contained in the NDDA.

The Federal Facility Agreement (FFA) dates for operational closure of these two tanks were revised in 2004 to October 31, 2006, for tank 19F and February 28, 2007, for tank 18F. In March 2006, DOE requested that these closure dates be extended by 13 months. SCDHEC did not concur with this extension request, so DOE initiated an informal dispute resolution per the FFA in April 2006.

\section{Waste Minimization/Pollution Prevention (WMin/P2) Program}

2006 Program Results and Highlight The SRS Pollution Prevention (P2) Program is mature and well integrated with site operations and cleanup activities. Accomplishments in 2006 included the following:

- SRS completed 25 documented P2 projects, resulting in an annualized avoidance of 4,785 cubic meters of hazardous and radioactive waste, and exceeding its performance goal of 2,804 cubic meters by more than 70 percent. Annual cost avoidance resulting from these $\mathrm{P} 2$ projects was $\$ 21.4$ million.

- The site's comprehensive industrial and office waste recycling programs managed more than 120,000 metric tons of materials, recycling more than 36 percent ( 853 metric tons) of the sanitary waste stream (e.g., routine office waste) and 32 percent $(2,943$ metric tons) of the industrial waste stream.

- SRS was awarded three National DOE P2 awards and was a co-winner of an additional award. Projects winning the three awards were forwarded to the next competition level and additionally won a P2 STAR award, a White House Closing the Circle (WHCTC) Award, and a WHCTC Honorable Mention Award. Winning nominations were: Green Fleet Team - Petroleum Reduction through Alternate Fuels, Savannah River's Recycle Opportunities Expand, Lead Recycle Program Restart, and SRS Deactivation and Decommissioning Activities.

In addition, SRS worked with DOE closure sites (Rocky Flats and Mound) to identify and receive excess supplies and waste packaging valued at about $\$ 950,000$. This avoided waste cost by the closure sites and resulted in material procurement savings at SRS.

The P2 Program met all DOE and regulatory agency reporting requirements. Working through the DOE Environmental Management (EM) branch, program support was provided to the DOE Headquarters (DOE-HQ) and National Nuclear Safety Administration (NNSA) P2 Programs. SRS hosted a video conference with the DOE-HQ EH P2 Workshop, with 10 employees participating, and made a presentation highlighting best practices at the NNSA P2 Workshop. 
SRS maintained its EPA Waste Wise membership by participating in the annual conference and submitting all required reports. The conference presentation entitled "Working with Your Community" highlighted the best community and employee outreach programs submitted to EPA for awards. SRS was one of only three presenters invited to participate in this session topic.

The SRS P2 Team supported the City of North Augusta (South Carolina) Kids Earth Day event, which included more than 30 exhibits to educate and share with those in attendance. The Environmental Science Educator's Cooperative (ESEC) and the SRS P2 Team joined together to host the 2006 ECOMEET, an environmental competition for middle school students. This year's event was held at the Silver Bluff Audubon Center, with 22 teams from eight counties participating.

SRS WMin/P2 Program Management SRS continued its commitment in 2006 to increasing P2 awareness and implementing waste management improvement opportunities. Pollution prevention is integral to the SRS Environmental Management Policy, Environmental Management System (EMS), and Integrated Safety Management System (ISMS). The WMin/P2 Program provides SRS a safe, effective, and environmentally responsible strategy for implementing specific waste reduction techniques based on current and projected information on waste generation, waste characterization, and ultimate waste disposal costs. The site embraces pollution prevention as a primary strategy to operate in a compliant, cost-effective manner that protects the environment and the safety and health of employees and the public. SRS's P2 Program establishes the environmental management preference of source reduction and recycling over treatment, storage, and disposal, and the preferred use of energy efficient and resource conservative practices and operations.

The WMin/P2 Program scope includes both infield generator and sitewide coordination programs. The generator program, responsible for implementation of facility-specific improvement initiatives, is funded through each generator's operating budget.

Sitewide program coordination, managed by the Waste Management Area Project organization, is separately funded and provides

- management support of WMin/P2 Program activities

- technical assistance for facility walkdowns, lifecycle waste cost analyses, and pollution prevention opportunity assessments

- forums for waste minimization and P2 information and technology exchanges

- employee P2 awareness and training programs

- recycling and disposition of contaminated-metal and large-equipment

- mechanisms to increase waste generator accountability through the Solid Waste Management Committee

- completion of required annual plans and reports

- implementation of sitewide initiatives such as sanitary waste recycling, "Green-IsClean" programs, and other cost-cutting measures

- establishment of a P2 component into the Site Communication Plan to increase public awareness and support 


\section{Comprehensive Environmental Response, Compensation, and Liability Act}

SRS was placed on the National Priority List in December 1989, under the legislative authority of CERCLA (Public Law 96-510), as amended by the Superfund Amendments and Reauthorization Act of 1986 (SARA, Public Law 99499). In accordance with Section 120 of CERCLA, DOE, EPA Region 4, and SCDHEC entered into the SRS FFA, which became effective August 16, 1993, and which directs the comprehensive environmental remediation of the site. Fifty-five FFA milestones were scheduled for completion in

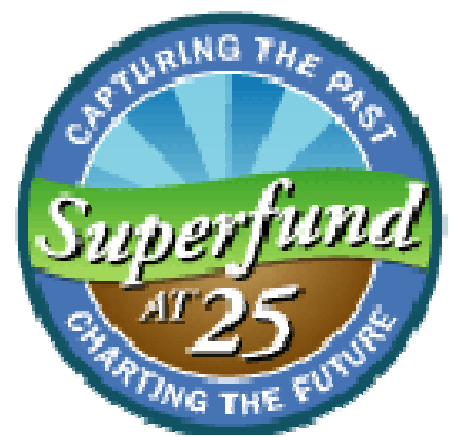
FY06; all were accomplished on or ahead of schedule.

SRS has 515 waste units in the Soil and Groundwater Closure Projects program. At the end of CY06, remediation was in progress, or had been completed, in 368 units and areas (334 complete and 34 in the remediation phase). Closure activities included the following:

- Ten RCRA Facility Investigation/Remedial Investigations (RFI/RIs) were initiated.

- Two remedial actions were initiated.

- One Interim Action Post-Construction Report was submitted.

- One removal action was initiated.

- Five records of decision (RODs) were submitted.

- Four RODs were approved.

- Five RODS with certification signatures were issued.

- One Remedial Site Evaluation Report was issued.

A listing of all waste units at SRS can be found in appendix C ("RCRA/CERCLA Units List") and appendix G ("Site Evaluation List") of the FFA.

\section{Emergency Planning and Community Right-to-Know Act}

The Emergency Planning and Community Right-to-Know Act (EPCRA) of 1986 requires facilities to notify state and local emergency planning entities about their hazardous chemical inventories and to report releases of hazardous chemicals. The Pollution Prevention Act of 1990 expanded the Toxic Chemical Release Inventory report to include source reduction and recycling activities.

\section{Tier II Inventory Report}

Under Section 312 of EPCRA, SRS completes an annual Tier II Inventory Report for all hazardous chemicals present at the site in excess of specified quantities during the calendar year. Hazardous chemical storage information is submitted to state and local authorities by March 1 for the previous calendar year. 


\begin{tabular}{|c|c|c|}
\hline $\begin{array}{l}\text { EPCRA } \\
\text { Citation }\end{array}$ & $\begin{array}{l}\text { Activity } \\
\text { Regulated }\end{array}$ & $\begin{array}{l}\text { Reported per } \\
\text { Applicable } \\
\text { Requirement }\end{array}$ \\
\hline $302-303$ & Planning Notification & Not Required ${ }^{a}$ \\
\hline 304 & $\begin{array}{l}\text { Extremely Hazardous } \\
\text { Substances Release } \\
\text { Notification }\end{array}$ & Not Required $^{a}$ \\
\hline $311-312$ & $\begin{array}{l}\text { Material Safety Data Sheet/ } \\
\text { Chemical Inventory }\end{array}$ & Yes \\
\hline 313 & $\begin{array}{l}\text { Toxic Release Inventory } \\
\text { Reporting }\end{array}$ & Yes \\
\hline
\end{tabular}

\section{Toxic Chemical Release Inventory Report}

Under Section 313 of EPCRA, SRS must file an annual Toxic Chemical Release Inventory report by July 1 for the previous year. SRS calculates chemical releases to the environment for each regulated chemical that exceeds its established threshold, and reports the release values to EPA on Form $\mathrm{R}$ of the report.

For 2006, SRS reported the following chemicals that exceeded their thresholds: chlorine, chromium, formic acid, lead, manganese, mercury, nickel, nitrate, nitric acid, sodium nitrite, and zinc. Lead, nitrate, and zinc were the largest contributors to the total releases. Specific details, including release amounts and detailed information about Toxic Release Inventory reporting, can be viewed on the EPA website at www.epa.gov/tri/.

\section{Executive Order 12856}

Executive Order 12856, "Federal Compliance with Right-to-Know Laws and Pollution Prevention Requirements," requires that all federal facilities comply with right-to-know laws and pollution prevention requirements. SRS complies with the applicable reporting requirements for EPCRA, as indicated in table 3-2, and the site incorporates the toxic chemicals on the Toxic Chemical Release Inventory report into its pollution prevention efforts.

\section{National Environmental Policy Act}

The National Environmental Policy Act (NEPA) establishes policies and goals for the protection, maintenance, and enhancement of the human environment in the United States. NEPA provides a means to evaluate the potential environmental impact of proposed federal actions and to examine viable alternatives (including the "no action" alternative) to those proposed actions.

A total of 296 SRS-related NEPA reviews were conducted in 2006 (table 3-3); several are still in progress. Following is a listing of major 2006 NEPA reviews that impact SRS: 
- Amended Record of Decision: Savannah River Site Processing Alternatives (DOE/EIS0082-S2) - This amended ROD describes DOE's decision to change the processing and disposition pathway for a fraction of the salt waste currently stored in the F- and H-Area tank farms. This action is called Interim Salt Processing. When the Salt Waste Processing Facility (SWPF) becomes operational, the remaining salt waste will be processed by high-capacity salt processing through the SWPF using caustic-side solvent extraction technology. The amended ROD was issued January 17 in Washington, DC.

- Supplement Analysis: Savannah River Site Spent Nuclear Fuel Management FEIS (DOE/EIS-0279) This supplement analysis (SA) reviews the proposed action to continue the use of H-Canyon to process Spent Nuclear Fuels (SNF) receipts and other highly enriched uranium material Table 3-3 Summary of NEPA Activities at SRS During 2006 through 2019. The SA is in

\begin{tabular}{lr}
\hline Type of NEPA Documentation & Number \\
\hline Categorical Exclusions & 275 \\
Actions Tiered to Previous NEPA Documentation & 14 \\
Environmental Assessments & 2 \\
Supplemental Analyses & 2 \\
Environmental Impact Statements & 2 \\
Amended Record of Decision & 1 \\
\hline Total NEPA Reviews & 296 \\
\hline
\end{tabular}
preparation.

- Supplement Analysis: Storage and Disposition of Weapons - Usable Fissile Materials FPEIS (DOE/EIS-0229) - This SA reviews the proposed action to continue the consolidation of surplus nonpit plutonium material from Hanford, Lawrence Livermore National Lab, and Los Alamos National Lab at SRS. The SA is in preparation.

- Global Nuclear Energy Partnership (GNEP) Programmatic Environmental Impact Statement (PEIS) - The GNEP initiative would encourage expansion of domestic and international nuclear energy production while reducing nuclear proliferation risks. The project-specific impacts of constructing and operating the following facilities will be considered within this PEIS: (1) a nuclear fuel recycling center to separate SNF into its reusable and waste components; (2) an advanced recycling reactor to destroy longlived radioactive elements in fuel while generating electricity; and (3) an advanced fuel cycle research facility to perform research into SNF recycling processes and other aspects of advanced nuclear fuel cycles. SRS is considered a potential site for one or more of these proposed facilities. The PEIS is in preparation.

- Supplement to the Stockpile Stewardship and Management PEIS - Complex 2030 (DOE/EIS-0236-S4) - The proposed action of this SPEIS is to continue currently planned modernization activities in the complex while selecting a site (potentially SRS) for a consolidated plutonium center for long-term research and development, surveillance, and pit manufacturing. Existing tritium operations at SRS would not be affected. As part of this NEPA review, the previously proposed SPEIS on Stockpile Stewardship and Management for a Modern Pit Facility has been cancelled. The SPEIS is in preparation.

- Draft National Pollutant Discharge Elimination System Stormwater Compliance Alternatives at the Savannah River Site Environmental Assessment (DOE/EA - 1563) - This NEPA review evaluates the potential environmental impacts associated with 
proposed and alternative actions at 38 SRS stormwater outfalls designed to protect the quality of state waters. The EA is in preparation.

- Environmental Assessment for the Replacement Source of Steam for A-Area at the Savannah River Site (DOE/EA - 1568) - This NEPA review evaluated the potential environmental impacts associated with constructing and operating a replacement steam generation plant (wood- and oil-fired) in A-Area. The EA was completed, and a Finding of No Significant Impact was published October 6.

\section{Safe Drinking Water Act}

The federal Safe Drinking Water Act (SDWA) was enacted in 1974 to protect public drinking water supplies. SRS domestic water is supplied by 17 separate systems, all of which utilize groundwater sources. The A-Area, D-Area, and KArea systems are actively regulated by SCDHEC, while the remaining 14 site water systems receive a reduced level of regulatory oversight.

Samples are collected and analyzed periodically by SRS and SCDHEC to ensure that all site

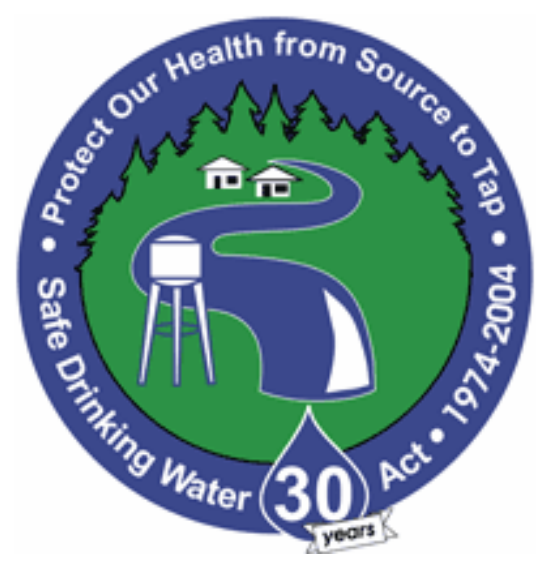
domestic water systems meet SCDHEC and EPA bacteriological and chemical drinking water quality standards. All samples collected in 2006 met these standards.

Although the B-Area Bottled Water Facility is not listed by SCDHEC as a public water system, SCDHEC's Division of Food Protection will continue to conduct periodic inspections of this facility. Results from routine bacteriological analyses and annual complete chemical analyses performed in 2006 met SCDHEC and FDA water quality standards.

SRS received no NOVs in 2006 under the SDWA.

\section{Clean Water Act}

\section{National Pollutant Discharge Elimination System}

The Clean Water Act (CWA) of 1972 created the National Pollutant Discharge Elimination System (NPDES) program, which is administered by SCDHEC under EPA authority. The program is designed to protect surface waters by limiting releases of nonradiological effluents into streams, reservoirs, and wetlands.

SRS had three NPDES permits in 2006:

- One permit for industrial wastewater discharges (SC0000175)

- Two general permits for stormwater discharges (SCR000000 for industrial and SCR100000 for construction)

More information about the NPDES permits can be found in chapter 4, "Effluent Monitoring." 
The results of monitoring for compliance with the industrial wastewater discharge permit at SRS were reported to SCDHEC in the site's monthly discharge monitoring reports, as required by the permit.

During 2006, SRS received from SCDHEC a final rating of "satisfactory"- the highest rating given-for the annual (2005) 2-week audit of the site's NPDES permitted outfalls. The 2006 audit was conducted in October, and no deficiencies or issues were identified. The final 2006 audit report has not been received from SCDHEC, so the 2006 rating is not known.

The outfalls covered by the industrial stormwater permit (SCR000000) were reevaluated again in 2005. This resulted in the development of a new sampling plan, which was implemented in 2006. Additional sampling was performed to determine the level of stormwater discharge compliance with new permit requirements. Results of stormwater outfall sampling appear in an effluent monitoring data table on the $\mathrm{CD}$ accompanying this report.

In 2005, SCDHEC issued a new stormwater general permit that required SRS stormwater discharges to meet more stringent guidelines. The site expanded the stormwater sampling program in 2006 to evaluate its stormwater outfalls against the more stringent requirements of the new permit. Several stormwater outfalls exceeded EPA benchmarks for iron, copper, zinc, and other trace metals. Nine outfalls had problems that prompted SCDHEC to request that SRS submit a permit application for each of those outfalls. Ten outfalls exceeded EPA benchmarks but were not of sufficient concern to require individual permits. These 10 outfalls will require some best management practices to meet EPA benchmarks. The remaining outfalls required no action. Based on an October 2005 agreement with SCDHEC, SRS remains in compliance with the industrial stormwater general permit.

As a result of heavy rain events in June 2006, sediment deposits escaped the approved control measures in place for construction activities at the MOX site in F-Area, and at sites located in D-Area and T-Area. The deposits impacted the wetlands adjacent to these areas. Repairs were made to the existing control measures, and additional measures were installed to bolster the impacted areas. Upon inspection of the impacted areas, SCDHEC and U.S. Army Corps of Engineers representatives determined that the sediments could remain in place, and that no further actions were necessary.

Under the Code of Federal Regulations (CFR) Oil Pollution Prevention regulation (40 CFR 112), SRS must report petroleum product discharges of 1,000 gallons or more into or upon the navigable waters of the United States, or petroleum product discharges in harmful quantities that result in oil sheens. No such incidents occurred at the site during 2006.

SRS has an agreement with SCDHEC to report petroleum product discharges of 25 gallons or more to the environment. Two such incidents occurred in 2006 - the first when a vendor tractor-trailer dump truck overturned at the C\&D Landfill due to shifting of its load. (Thirty-five gallons of diesel fuel and hydraulic fluid spilled onto the ground.) The second incident occurred after inadequate repairs to a leaking fuel line. (Thirty-nine gallons of diesel fuel spilled onto the ground.) In each case, the spill was cleaned up, and contaminated soil was disposed of at the Three Rivers Landfill. 


\section{Notices of Violation (NPDES)}

SRS’s 2006 compliance rate for the NPDES program under the CWA was 99.94 percent.

Three exceedances occurred at SRS NPDES outfalls in 2006. Two exceedances for ammonia occurred at Outfall G-10 when one of two oxidation ditches was removed from service for valve repairs. The ditch was left out of service after the repairs then placed back into service; subsequent samples were within permit limits. An exceedance for lead occurred at Outfall F-08 when a deactivated instrument air system was restarted. The system was removed from service, and subsequent samples were within permit limits. A table showing outfall location, probable cause, and corrective actions for 2006 exceedances can be found in chapter 4 (table 4-4).

The site received two NOVs from SCDHEC under the NPDES program in 2006. The NOVs were issued in response to the $\mathrm{G}-10$ and $\mathrm{F}-08$ exceedances discussed above. No fines were issued and no responses required because SCDHEC was satisfied with SRS's documentation in the monthly discharge monitoring reports.

\section{Dredge and Fill; Rivers and Harbors}

The CWA, Section 404, "Dredge and Fill Permitting," as amended, and the Rivers and Harbors Act, Section 9 and 10, "Construction Over and Obstruction of Navigable Waters of the United States,” protect U.S. waters from dredging and filling and construction activities by the permitting of such projects. Dredge-and-fill operations in U.S. waters are defined, permitted, and controlled through implementation of federal regulations in 33 CFR and 40 CFR.

SRS conducted activities under four Nationwide Permits (NWPs) in 2006 as part of the NWP program (general permits under Section 404), but none under an individual Section 404 permit. The 2006 activities were as follows:

- Dam construction on an unnamed tributary to Fourmile Branch for the Mixed Waste Management Facility Groundwater Interim Measures project was completed in 2000 under NWP-38, "Hazardous Waste Cleanup.” However, mitigation for the impact to wetlands is still pending and must be addressed before the permit can be considered closed.

- Construction of the Mixed Waste Management Facility dam intake structure modification continued under NWP-38, "Hazardous Waste Cleanup.” The modification will improve the efficiency of the treatment system for tritium. The approved permit was received in 2004. The intake structure modification to dam was completed in February, and the permit was closed in March.

- Installation of a well by Soil and Groundwater Closure Projects in a wetland adjacent to Tims Branch was covered under NWP-5, "Scientific Measurement Devices.” The installation was completed in March, and the permit was considered closed.

- Installation of a sampling platform downstream of the SC Highway 125 bridge crossing Steel Creek was covered under NWP-5, "Scientific Measurement Devices." The installation is scheduled for 2007. 
- Installation of a sampling platform upstream of the Road $\mathrm{C}$ bridge crossing Fourmile Branch was covered under NWP-5, "Scientific Measurement Devices." The platform was completed in November.

\section{Construction in Navigable Waters}

SCDHEC Regulation 19-450, "Permit for Construction in Navigable Waters," protects the state's navigable waters. The only state navigable waters at SRS are Upper Three Runs Creek (through the entire site) and Lower Three Runs Creek (upstream to the base of the PAR Pond Dam).

No Construction in Navigable Waters permit activities occurred in 2006.

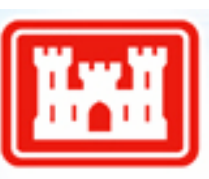

\section{Federal Insecticide, Fungicide, and Rodenticide Act}

The Federal Insecticide, Fungicide, and Rodenticide Act controls the application of restricted-use pesticides at SRS through a state-administered certification program. The site complies with these requirements through Procedure 8.1, "Federal Insecticide, Fungicide, and Rodenticide Act Compliance for Use of Pesticides," of the Environmental Compliance Manual (WSRC 3Q).

The SRS pesticide procedure provides guidelines for pesticide use and requires that applicators of restricted-use pesticides be state certified. Extensive revisions of the procedure, begun in 2004, were completed in 2005 to improve the efficiency of the site pesticide-application approval process. The most significant changes involved (1) dropping the requirement for a formal pesticide program plan for the application of unrestricted pesticides and (2) renewing emphasis on the importance of completing a Pesticide Activity Report (PAR) within 14 days (formerly 15) of any site pesticide application.

Additional changes in the procedure - some involving expansion of the site's restricted-use pesticide list to include three pesticides formerly on the unrestricted list, but most editorial in nature-were set in motion late in 2006 and are expected to be implemented during 2007.

\section{Clean Air Act}

\section{Regulation and Delegation}

The Clean Air Act (CAA) and the Clean Air Act Amendments (CAAA) of 1990 provide the basis for protecting and maintaining air quality. Though EPA still maintains overall authority for the control of air pollution, regulatory authority for all types of emission sources has been delegated to SCDHEC. Therefore, SCDHEC must ensure that its air pollution regulations are at least as stringent as the federal requirements. This is accomplished through SCDHEC Regulation 61-62, "Air Pollution Control Regulations and Standards." The various CAAA Titles covered by these SCDHEC regulations are discussed below. 


\section{Title V Operating Permit Program}

Under the CAA, and as defined in federal regulations, SRS is classified as a "major source" and, as such, falls under the CAAA Part 70 Operating Permit Program. On February 19, 2003, SCDHEC's Bureau of Air Quality issued SRS its Part 70 Air Quality Permit, TV-0080-0041, which had an effective date of April 1, 2003, and an expiration date of March 31, 2008. As issued, the Part 70 Air Quality Permit regulates both radioactive and nonradioactive toxic and criteria pollutant emissions from approximately 30 nonexempt emission units, with each emission unit having specific emission limits, operating conditions, and monitoring and reporting requirements. The permit also contains a listing, known as the Insignificant-Activities List, identifying approximately 1,200 SRS sources that are exempt based on insignificant emission levels, or on equipment size or type. Two air construction permit applications were submitted to SCDHEC in 2006. The applications were for SRS plans to (1) install and operate a biomass boiler and an oil-fired boiler to provide steam to A-Area and (2) discontinue operation of the two aging 784-A coal-fired boilers.

Also, on February 1, 2006, WSRC assumed operational responsibility for the 484-D Powerhouse facility from South Carolina Electric and Gas (SCE\&G), which had operated the facility for DOE under a separate contract since 1995. The 484-D Powerhouse had an SCDHEC Part 70 Air Quality Permit (TV-080-0044), effective May 1, 2001, with an expiration date of April 30, 2006. Leading up to the February 2006 transition, WSRC conducted a due-diligence assessment to ensure that the facility was in compliance with all South Carolina and federal air regulations. No air compliance issues were identified. Beginning in late 2006, SRS personnel have worked with SCDHEC's Bureau of Air Quality representatives to finalize a new 484-D Part 70 Air Quality Permit that will replace the existing permit, which expired April 30, 2006.

During 2006, SCDHEC issued two revisions to the SRS Part 70 Air Quality Permit (TV0080-0041) that incorporated several minor modifications and one administrative change. No revisions were issued by SCDHEC to the 484-D Powerhouse Part 70 Air Quality Permit (TV-0080-0044).

Compliance with the SRS Part 70 Air Quality Permit conditions was evaluated by SCDHEC during 2006 as part of the Annual Air Compliance Inspection conducted the week of June 19. It was determined that SRS air emission sources were operating in compliance with their respective permit conditions and limitations.

\section{Notices of Violation (CAA)}

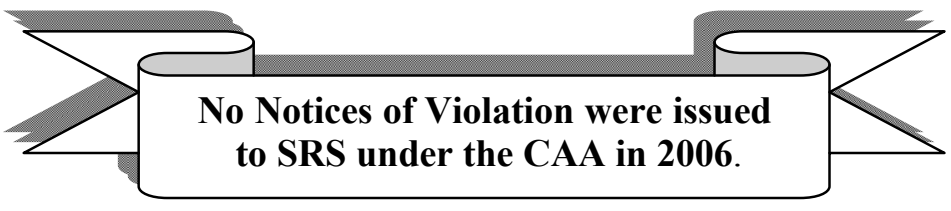

\section{National Emission Standards for Hazardous Air Pollutants}

The National Emission Standards for Hazardous Air Pollutants (NESHAP) is a CAAimplementing regulation that sets air quality standards for air emissions containing hazardous air pollutants, such as radionuclides, benzene, and asbestos. 
NESHAP Radionuclide Program The current list of 189 air pollutants includes all radionuclides as a single item. Regulation of these pollutants has been delegated to SCDHEC; however, EPA Region 4 continues to regulate some aspects of NESHAP radionuclides.

NESHAP Radionuclide Program Subpart H of 40 CFR 61 was issued December 15, 1989, after which an evaluation of all air emission sources was performed to determine compliance status. DOE's Savannah River Operations Office (DOE-SR) and EPA Region 4 signed a Federal Facility Compliance Agreement (FFCA) October 31, 1991, providing a schedule to bring SRS's emissions monitoring into compliance with regulatory requirements. The FFCA was officially closed — and the site declared compliant—by EPA Region 4 May 10, 1995. Subpart H was revised by EPA September 9, 2002, with an effective date of January 1, 2003. This revision added inspection requirements for existing SRS sources and allowed the use of ANSI N13.1-1999 for establishing monitoring requirements. SRS is performing all required inspections, has monitoring systems compliant with the regulation, and remains in compliance with Subpart H of 40 CFR 61.

During 2006, the maximally exposed individual effective dose equivalent, calculated using the NESHAP-required CAP88 computer code, was estimated to be 0.06 mrem $(0.0006$ $\mathrm{mSv})$, which is 0.6 percent of the 10 mrem per year $(0.10 \mathrm{mSv}$ per year) EPA standard (chapter 6, "Potential Radiation Doses").

NESHAP Nonradionuclide Program SRS uses many chemicals identified as toxic or hazardous air pollutants, but most of them are not regulated under the CAA or under federal NESHAP regulations. Except for asbestos, SRS facilities and operations do not fall into any of the "categories" listed in the original subparts. Under Title III of the federal Clean Air Act Amendments (CAAA) of 1990, EPA in December 1993 issued a final list of hazardous air pollutant-emitting source categories potentially subject to maximum achievable control technology (MACT) standards.

During 2005, EPA revised one MACT rule that applies to the SRS Consolidated Incineration Facility (CIF). The rule, "Final Standards for Hazardous Air Pollutants for Hazardous Waste Combustor (Phase I Final Replacement Standards and Phase II)," became effective September 14, 2005, and had a compliance date of October 14, 2008. Because CIF operations were suspended in November 2000, with no plans to restart the facility, SRS submitted a permit modification to SCDHEC's Bureau of Air Quality, requesting that the CIF be removed from the SRS Part 70 Air Quality permit. SCDHEC subsequently issued a revision to the permit October 17, 2006.

On September 13, 2004, EPA finalized a MACT rule that applies to the coal-fired steam boilers at the 784-A and 484-D powerhouse facilities. The rule, "National Emission Standards for Hazardous Air Pollutants for Industrial, Commercial, and Institutional Boilers and Process Heaters," has a compliance date of September 13, 2007, and requires facilities to meet more stringent emissions limits dealing with particulate matter (PM), mercury (Hg), and hydrogen chloride (HCL) emissions. During 2006, 484-D Powerhouse Facility personnel made preparations to conduct the necessary testing during the 20072008 timeframe to demonstrate compliance with the new emission limits without the significant expenditure of capital funds. In June 2006, a MACT extension request was submitted to SCDHEC's Bureau of Air Quality requesting a one-year extension from the September 2007 compliance date so SRS could replace the aging A-Area boilers with a 
smaller wood-fired boiler and an oil-fired boiler capable of meeting the lower MACT emission limits. That compliance extension request was approved by SCDHEC September 5.

NESHAP Asbestos Abatement Program SRS began its asbestos abatement program in 1988 and continues to manage asbestos-containing material by "best management practices." Site compliance in asbestos abatement, as well as demolitions, falls under South Carolina and federal regulations, including SCDHEC Regulation R.61-86.1 ("Standards of Performance for Asbestos Projects") and 40 CFR 61, Subpart M ("National Emission Standards for Hazardous Air Pollutants - Asbestos").

During 2006, SRS personnel removed and disposed of an estimated 429 square feet, 14,017 linear feet, and 54 cubic feet of regulated asbestos-containing material. SRS personnel also removed 254,761 square feet and 10,768 linear feet, and 270 cubic feet of nonregulated asbestos-containing material.

Radiological asbestos waste was disposed of at the SRS E-Area low-level vaults, engineered trench, and slit trench, which are permitted by SCDHEC as asbestos waste disposal sites. Nonradiological asbestos waste was disposed of at the Three Rivers Solid Waste Authority Landfill and the C\&D Landfill (Building 632-G), which also are SCDHEC-approved asbestos waste landfills.

\section{Accidental Release Prevention Program}

Under Title III of the CAAA, EPA established a program for the prevention of accidental releases of large quantities of hazardous chemicals. As outlined in Section 112(r), any facility that maintains specific hazardous or extremely hazardous chemicals in quantities above specified thresholds must develop a risk management program (RMP). The RMP establishes methods that will be used for the containment and mitigation of large chemical spills. No such accidental releases occurred at SRS during 2006.

SRS's RMP maintains hazardous and extremely hazardous chemical inventories below the threshold quantity. This cost-effective approach minimizes the regulatory burden of 112(r) but does not eliminate any liability associated with the general duty clause, as stated in 112(r)(1). No hazardous or extremely hazardous chemical releases have been required to be reported by SRS.

EPA issued a revision to its RMP final rule in 2004, changing reporting requirements of its chemical accident prevention regulations. Chemical facilities subject to these regulations now are required to submit significant-chemical-accident information and emergency contact information. These changes seek to improve and assist federal, state, and local risk management programs in implementing the new homeland security measures.

\section{Ozone-Depleting Substances}

Title VI of the CAAA of 1990 addresses stratospheric ozone protection. This law requires that EPA establish regulations to phase out the production and consumption of ozonedepleting substances (ODSs). 
Several sections of Title VI of the CAAA of 1990, along with recently established EPA regulations found in 40 CFR 82, apply to the site. The ODSs are regulated in three general categories, as follows:

- Class I substances - chlorofluorocarbons (CFCs), Halons, carbon tetrachloride, methyl chloroform, methyl bromide, and hydrobromofluorocarbons (HBFCs)

- Class II substances - hydrochlorofluorocarbons (HCFCs)

- Substitute substances

The "Savannah River Site Refrigerant Management Plan," completed and issued in September 1994, provides guidance to assist SRS and DOE in the phaseout of CFC refrigerants and equipment.

SRS has reduced CFC refrigerant usage in large ODS emission sources more than 99 percent compared to 1993 baseline data.

The SRS CAAA of 1990 Title V operating air permit application includes ODS emission sources. All large (greater than or equal to 50-pound charge) heating, ventilation, and air conditioning/chiller systems for which there are recordkeeping requirements are included as fugitive emission sources.

SRS is phasing out its use of Halon as part of a goal to eliminate the use of Class I ODSs by 2010 "to the extent economically practicable." A Halon 1301 management plan (F-ESR-G-00120, November 16, 2005) and schedule have been developed by Fire Protection Services to help meet DOE's goal. The plan includes an SRS Halon 1301 fire suppression system inventory that identifies systems in operation, systems abandoned in place, and systems that have been dismantled and taken to the DOE complex's Halon repository, located at SRS.

Halon 1301 total inventory on site decreased from 73,800 pounds in 2005 to 71,290 pounds in 2006. The site had an inventory of 51,717 pounds of stored Halon 1301 at the end of 2006. In addition, 19,573 pounds were contained in the 86 operating systems at the end of 2006 (down from 111 in 2002).

\section{Air Emissions Inventory}

SCDHEC Regulation 61-62.1, Section III ("Emissions Inventory"), requires compilation of an air emissions inventory to locate all sources of air pollution and to define and characterize the various types and amounts of pollutants. To demonstrate compliance, SRS personnel in 1993 conducted the initial comprehensive air emissions inventory, which identified approximately 5,300 radiological and nonradiological air emission sources. Source operating data and calculated emissions from 1990 were used to establish the SRS baseline emissions and to provide data for air dispersion modeling. This modeling was required to demonstrate sitewide compliance with Regulation 61-62.5, Standards No. 2 (“Ambient Air Quality Standards") and No. 8 ("Toxic Air Pollutants").

Regulation 61-62.1, Section III, which was revised August 26, 2005, requires that inventory data be updated and recorded annually but reported to SCDHEC on a reporting frequency (formerly every even year) - either an annual cycle for "Type A" sources or a 3-year cycle for "Type B" and "Nonattainment Area" sources—-based on "minimum 
reporting thresholds." The thresholds depend on the actual tons per year of specific criteria pollutants.

SRS is classified as a Type B source, and now is required to report only every third year, reducing the cost burden associated with annual emission inventories. However, the acquired D-Area Powerhouse is a Type A source and will report an emission inventory every year. The site is required to compile and report D-Area Powerhouse's CY 2006 emissions by March 31, 2007, to SCDHEC. SRS is not required to compile or report any other CY 2006 emissions data to SCDHEC. During 2006, the site collected CY 2005 operating data for permitted and other significant sources in accordance with SRS procedures and guidelines. Because data collection for all SRS sources begins in January and requires up to 6 months to complete, this (2006) site environmental report provides emissions data for CY 2005. Compilation of 2008 data will be completed in 2009, submitted to SCDHEC, and reported in the SRS Environmental Report for 2009.

\section{Toxic Substances Control Act}

The Toxic Substances Control Act (TSCA) gives EPA comprehensive authority to identify and control chemical substances manufactured, imported, processed, used, or distributed in commerce in the United States. Reporting and record keeping are mandated for new chemicals and for any chemical that may present a substantial risk of injury to human health or the environment.

Polychlorinated biphenyls (PCBs) have been used in various SRS processes. The use, storage, and disposal of these organic chemicals are specifically regulated under $40 \mathrm{CFR}$ 761, which is administered by EPA. SRS has a well-structured PCB program that complies with this TSCA regulation, with DOE orders, and with WSRC policies.

No NOVs were issued to SRS in connection with its 2006 PCB compliance program activities. The site did, however, determine that one container of legacy remediation waste containing PCBs had not been properly labeled and identified as PBC waste. The error was discovered during preparations to ship the container off site for disposal. SRS immediately took corrective actions, and the waste subsequently was disposed in an appropriately permitted facility. The site disclosed this matter to EPA Region IV promptly after discovery of the error.

The site's 2005 PCB document log was completed in full compliance with 40 CFR 761, and the 2005 annual report of onsite PCB disposal activities was submitted to EPA Region 4 in July 2006. The disposal of nonradioactive PCBs routinely generated at SRS is conducted at EPA-approved facilities within the regulatory period. For some forms of radioactive PCB wastes, disposal capacity is not yet available, and the wastes must remain in long-term storage. Such wastes are held in TSCA-compliant storage facilities in accordance with 40 CFR 761.

\section{Endangered Species Act}

The Endangered Species Act of 1973, as amended, provides for the designation and protection of wildlife, fish, and plants in danger of becoming extinct. The act also protects and conserves the critical habitats on which such species depend. 


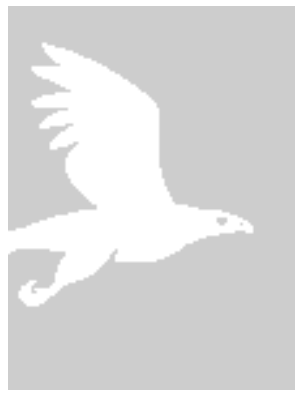

Several threatened and endangered species exist at SRS, including the wood stork, the red-cockaded woodpecker, the bald eagle, the shortnose sturgeon, the pondberry, and the smooth purple coneflower. Programs designed to enhance the habitat and survival of such species are in place.

A biological evaluation was prepared for SRS in 2006 to support activities addressed in the draft "Environmental Assessment for the Safeguard and Security Upgrades for storage of Plutonium Materials at Savannah River Site," (DOE/AE-1563), and in the "Selected National Discharge Elimination System Stormwater Permit Compliance Alternatives at the Savannah River Site." In 2006, no biological assessments or biological evaluations were necessary for forestry related activities. None of these activities were found to have had any significant potential impact on threatened and endangered species.

\section{National Historic Preservation Act}

The National Historic Preservation Act (NHPA) of 1966, Section 106, governs the archaeological and historical resources. SRS ensures that it is in compliance with the NHPA through several processes. The Cold War Programmatic Agreement and the SRS Cold War Built Environment Cultural Resource Management Plan are in place and being implemented. The Artifact Selection team - which includes DOE, WSRC, and the University of South Carolina Savannah River Archaeological Research Program (SRARP) - meets monthly and is responsible for overseeing the selection, collection, and curation of Cold War-era artifacts from buildings prior to decommissioning and demolition activities.

In addition, the site helps ensure that it remains in compliance with NHPA through its Site Use Program. All sites being considered for activities such as construction are evaluated by SRARP personnel to ensure that archaeological or historic sites are not impacted. Reviews of

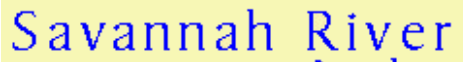
Archaeological

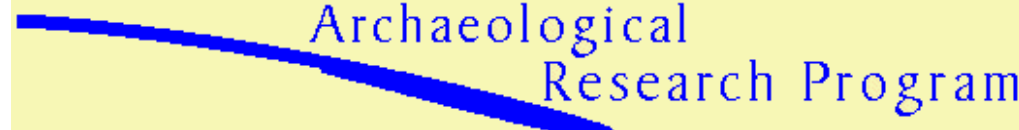
timber compartment prescriptions include surveying for archaeological resources and documenting areas of importance with regard to historic and prehistoric significance.

SRARP personnel reviewed 30 site-use packages during 2006, of which 12 proposed land modifications resulted in the need to survey 701 acres. The remaining site-use packages were found to have no activities of significant impact in terms of the NHPA. SRARP personnel also surveyed 182 acres in 2006 in support of onsite forestry activities.

The surveys of the 883 total acres resulted in 48 site investigations - 38 of which involved new archaeological sites - and in revisits to 10 previously recorded sites for cultural resources management.

In compliance with NHPA, artifacts recovered through daily compliance activities and the analysis of artifacts recovered during Phase III investigations of site 38AK155 must be curated. A total of 11,279 artifacts were curated during FY 2006 by SRARP. 


\section{Floodplains and Wetlands}

Under 10 CFR, Part 1022 ("Compliance with Floodplains and Wetlands Environmental Review Requirements"), DOE establishes policies and procedures for implementing its responsibilities in terms of compliance with Executive Orders 11988 ("Floodplain Management") and 11990 ("Protection of Wetlands"). Part 1022 includes DOE policies regarding the consideration of floodplains/wetlands factors in planning and decision making. It also includes DOE procedures for identifying proposed actions involving floodplains/wetlands, providing early public reviews of such proposed actions, preparing floodplains/wetlands assessments, and issuing statements of findings for actions in floodplains.

In 2006, two floodplains/wetlands assessments were completed to ensure compliance with 10 CFR, Part 1022. The first assessment, entitled "Floodplain/Wetland Assessment for National Pollutant Discharge Elimination System (NPDES) Stormwater Compliance Alternatives at the Savannah River Site," was conducted to support the SRS's efforts to comply with NPDES limits at various stormwater outfalls. It was determined that no activities would be conducted in wetlands or floodplains. However, depending on the alternative selected to resolve the compliance issue, the hydrology of the some of the wetlands below the outfalls could be affected.

The second assessment, entitled "Floodplain/Wetland Assessment for the Replacement Source of Steam for A-Area at the Savannah River Site," was conducted in support of a proposed steam generation facility in A-Area. It was determined that no activities would be conducted in wetlands or floodplains. Depending on the specific location selected, there could be a slight impact on area wetlands due to elimination of water discharged to the outfall going to the wetland.

\section{Executive Order 11988}

Executive Order 11988 ("Floodplain Management") was established to avoid long- and short-term impacts associated with the occupancy and modification of floodplains. The evaluation of impacts to SRS floodplains is ensured through the NEPA Evaluation Checklist and the site-use system. Site-use applications are reviewed for potential impacts by WSRC, DOE-SR, the USDA Forest Service-Savannah River and the Savannah River Ecology Laboratory (SREL), as well as by professionals from other organizations.

\section{Executive Order 11990}

Executive Order 11990 ("Protection of Wetlands") was established to mitigate adverse impacts to wetlands caused by the destruction and modification of wetlands, and to avoid new construction in wetlands wherever possible. Avoidance of impact to SRS wetlands is ensured through the site-use process, various departmental procedures and checklists, and project reviews by the SRS Wetlands Task Group. Many groups and individualsincluding scientists from SRNL, SREL, and the Environmental Services Section-review site-use applications to ensure that proposed projects do not impact wetlands. 


\section{Environmental Release Response and Reporting}

\section{Response to Unplanned Releases}

Environmental Permitting and Monitoring (EPM) personnel respond to unplanned environmental releases, both radiological and nonradiological, upon request by area operations personnel. No unplanned environmental releases occurred at SRS in 2006 that required the sampling and analysis services of EPM.

\section{Occurrences Reported to Regulatory Agencies}

Federally permitted releases comply with legally enforceable licenses, permits, regulations, or orders. If a nonpermitted release to the environment of a reportable quantity or more of a hazardous substance (including radionuclides) occurs, CERCLA requires notification of the National Response Center. Also, the CWA requires that the National Response Center be notified if an oil spill causes a "sheen" on navigable waters, such as rivers, lakes, or streams. Oil spill reporting has been reinforced with liability provisions in the CERCLA National Contingency Plan.

SRS has had no CERCLA-reportable releases since 1999.

No notifications required by CERCLA or SCDHEC memoranda of understanding had to be made by SRS during 2006. The site recorded and cleaned up the following nonreportable spills; six chemical, eight sewage, five motor oil, 25 hydraulic oil, 13 diesel fuel, three gasoline, and two E-85 gas/ethanol blend.

EPCRA (40 CFR 355.40) requires that reportable releases of extremely hazardous substances or CERCLA hazardous substances be reported to any local emergency planning committees and state emergency response commissions likely to be affected by the release. No EPCRA-reportable releases occurred at SRS in 2006.

\section{Site Item Reportability and Issues Management Program}

The Site Item Reportability and Issues Management (SIRIM) program, mandated by DOE Order 232.1A ("Occurrence Reporting and Processing of Operations Information"), is designed to ". . . establish a system for reporting of operations information related to DOEowned or operated facilities and processing of that information to provide for appropriate corrective action ...." It is the intent of the order that DOE be ". . . kept fully and currently informed of all events which could (1) affect the health and safety of the public; (2) seriously impact the intended purpose of DOE facilities; (3) have a noticeable adverse effect on the environment; or (4) endanger the health and safety of workers."

Of the 149 SIRIM-reportable events in 2006, the following were categorized as environmental:

- NOV, Outfall F-08 - On November 7, SRS received an NOV from SCDHEC that the monthly average concentration limit for lead at Outfall F-08 had been exceeded in August.

- Small Liquid Spill Inside SeaLand Waste Container at 400-D - On June 15, a small amount of liquid was found where a tank had been loaded into an open-top SeaLand storage container on a waste storage pad in 400-D area. The tank, from 420-D, was 
staged in a Radioactive Materials Area awaiting disposal. The spill was discovered when the tank was removed from the SeaLand to allow adjustment of the support cribbing.

- NOV, Outfall G-10 - On June 6, SRS received an NOV from SCDHEC related to the exceedance of maximum and daily NPDES ammonia limits at outfall G-10 for March 2006.

- Tropical Storm Alberto Rainfall Erosion - The rainfall experienced from tropical storm Alberto June 14 caused sediment to travel beyond erosion control measures and impact three SRS wetland locations (the site of the future MOX facility, the 488-D Ash Basin CERCLA remediation site, and the TNX discharge gully remediation site).

- Small Liquid Spill at 211-F- Site D\&D reported that a small liquid leak occurred November 30 during a tap-and-drain evolution of a sump water line originating from the 221-F Canyon, and exited from the canyon to a basin. The leak (approximately 8 "x 8 ") occurred in a radiologically clean area. The maximum activity was 45,000 $\mathrm{dpm} / 100 \mathrm{~cm}^{2}$ beta-gamma, $<200 \mathrm{dpm} / 100 \mathrm{~cm}^{2}$ alpha.

\section{Assessments/Inspections}

The SRS environmental program is overseen by a number of organizations, both outside and within the DOE complex. In 2006, the WSRC environmental appraisal program consisted of self and independent assessments. The program ensures the recognition of noteworthy practices, the identification of performance deficiencies, and the initiation and tracking of associated corrective actions until they are satisfactorily completed. The primary objectives of the WSRC assessment program are to ensure compliance with regulatory requirements and to foster continuous improvement. The program is an integral part of the site's Safety Management System and supports the SRS Environmental Management System, which continues to meet the standards of International Organization for Standardization (ISO) 14001. (ISO 14000 is a family of voluntary environmental management standards and guidelines.)

WSRC conducted several environmental program-level assessments in 2006. The topics included

- Waste Management (Offsite Waste Management Facilities)

- Inactive Waste Sites and Releases (Closure and Post Closure)

- Laboratory Information Management System (LIMS)

- Surface Water Quality (Floodplain Management and Wetlands Protection)

- Environmental, Emergency, and Regulatory Notifications (Toxic Chemical Management and Release Reporting)

- Air Quality Protection (Ozone-Depleting Substances/Refrigerant Management)

- Waste Management (Public Involvement)

During 2006, DOE-SR Environmental Quality and Management Division personnel continued to perform direct oversight and evaluation of WSRC's self-assessment program. Completed DOE assessments have met with positive results; routine assessments have 
promoted improvement and helped ensure the adequacy of environmental programs and operations at SRS.

SCDHEC and EPA personnel conducted external inspections of the SRS environmental program for regulatory compliance. Agency representatives performed several comprehensive compliance inspections in 2006, as follows:

- RCRA Compliance Evaluation Inspection - The 2006 compliance evaluation inspection was conducted by EPA and SCDHEC. An October 16, 2006, letter from SCHEC noted, "No deficiencies were cited as a result of the inspection. You are to be commended for your excellent hazardous waste management program."

- Annual Air Compliance Inspection - SCDHEC conducted the annual air compliance inspection of operating SRS permitted sources. The site was found to be in compliance with each source's respective permit condition and requirement.

- Annual Underground Storage Tank Inspection - SCDHEC inspected the site's underground storage tanks. All were found to be in compliance with applicable regulations.

- Annual NPDES 3560 Compliance Audit - SCDHEC conducted the annual 3560 environmental audit of the site's NPDES-permitted outfalls. As of December 31, SRS had not received the final audit report, so the final rating for the site was not known.

- Quarterly Inspections of SRS Bottled Water Facility - SCDHEC conducted quarterly inspections of the SRS Bottled Water Facility. The facility was found to be in compliance.

- 632-G C\&D Landfill, 288-F Industrial Waste Landfill, and Saltstone InspectionSCDHEC conducted quarterly inspections, and all the sites were found to be satisfactory, with no observed deficiencies.

- Interim Sanitary Landfill - SCDHEC personnel conducted an annual postclosure inspection, and the site was found to be satisfactory, with no observed deficiencies.

- Groundwater Comprehensive Monitoring Evaluation - SCDHEC conducted an unannounced RCRA inspection of SRS's groundwater program. No deficiencies or permit violations were cited.

- 488-4D, Ash Landfill - A permit application was filed in February 2006 for the disposal of D-Area Powerhouse ash at the 488-4D Ash Landfill.

\section{Environmental Training}

The site's environmental training program identifies training activities to teach job-specific skills that protect the employee and the environment, in addition to satisfying regulatory training requirements. Regularly scheduled classes in this program at SRS include such topics as Environmental Laws and Regulations, Hazardous Waste Worker, Hazardous and Radiological Waste Characterization, and the Environmental Compliance Authority course. A self-taught Environmental Laws and Regulations course is available for technical personnel and is updated annually by the Environmental Services Section. More than 60 environmental program-related training courses are listed in the site training database, and individual organizations schedule and perform other facility-specific, environment-related training to ensure that operations and maintenance personnel, as well as environmental 
professionals, have the knowledge and skills to perform work safely and in a manner that protects the environment.

\section{Environmental Permits}

SRS had 420 construction and operating permits in 2006 that specified operating levels for each permitted source. Table 3-4 summarizes the permits held by the site during the past 5 years. These numbers reflect only permits obtained by WSRC for itself and for other SRS contractors that requested assistance in obtaining permits. It also should be noted that these numbers include some permits that were voided or closed some time during the calendar year (2006).

Table 3-4

SRS Construction and Operating Permits, 2002-2006

\begin{tabular}{lrrrrr}
\hline \multirow{2}{*}{ Type of Permit } & \multicolumn{5}{c}{ Number of Permits } \\
\cline { 2 - 6 } & $\mathbf{2 0 0 2}$ & $\mathbf{2 0 0 3}$ & $\mathbf{2 0 0 4}$ & $\mathbf{2 0 0 5}$ & $\mathbf{2 0 0 6}$ \\
\hline Air & 150 & $2^{\mathrm{a}}$ & 3 & 1 & 2 \\
Army Corps of Engineers Nationwide Permit & 5 & 5 & 3 & 4 & 5 \\
Domestic Water & 203 & 202 & 203 & 207 & 207 \\
Industrial Wastewater & 66 & 60 & 56 & 63 & 70 \\
NPDES Discharge & 1 & 1 & 1 & 1 & 2 \\
NPDES No Discharge & 1 & 1 & 1 & 0 & 1 \\
NPDES Stormwater & 2 & 2 & 2 & 2 & 2 \\
RCRA & 1 & 1 & 1 & 1 & 1 \\
Sanitary Wastewater & 133 & 109 & 104 & 106 & 106 \\
SCDHEC 401 & 0 & 0 & 0 & 0 & 0 \\
SCDHEC Navigable Waters & 1 & 0 & 0 & 0 & 0 \\
Solid Waste & 2 & 3 & 4 & 4 & 3 \\
Underground Injection Control & 18 & 19 & 18 & 21 & 14 \\
Totals & 590 & 412 & 403 & 417 & 420 \\
\hline a This number was revised to include the Title V Operating Permit, which includes all SRS air emission sources \\
and one construction permit.
\end{tabular}


Editor's note: The "Environmental Compliance" chapter is unique in that its number of contributing authors is far greater than the number for any other chapter in this report. Space/layout constraints prevent us from listing all of them and their organizations on the chapter's first page, so we list them here instead. Their contributions, along with those of the report's other authors, continue to play a critical role in helping us produce a quality documentand are very much appreciated.

Brent Blunt, ESS

Ron Campbell, ESS

Paul Carroll, ESS

John Cook, SGCP

Keith Dyer, ESS

Tim Faugl, ESS

Natalie Ferguson, WMAP

Don Frazier, SGCP
Linda Karapatakis, ESS

Linn Liles, ESS

Jeff Lintern, ESS

Nancy Lowry, ESS

Bill Maloney, ESS

Al Mamatey, ESS

Tim McCormick, I\&S
Hall Morris, ESS

Vernon Osteen, ESS

Bill Payne, ESS

Paul Rowan, ESS

Barry Shedrow, ESS

Stuart Stinson, ESS

Ben Terry, ESS 


\title{
Effluent Monitoring
}

\author{
Paul Carroll, Pete Fledderman, Donald Padgett, and Monte Steedley \\ Environmental Services Section
}

Timothy Jannik

Savannah River National Laboratory

\begin{abstract}
二 ffluent monitoring at the Savannah River Site (SRS) is conducted to demonstrate compliance with applicable standards and regulations. Site effluent monitoring activities are divided into radiological and nonradiological programs. A complete description of sampling and analytical procedures used for effluent monitoring by the Environmental Permitting and Monitoring group of the site's Environmental Services Section can be found in sections 1101-1111 (SRS EM Program) of the Savannah River Site Environmental Monitoring Section Plans and Procedures, WSRC-3Q1-2, Volume 1. A summary of data results is presented in this chapter; more complete data can be found in tables on the CD included with this report.
\end{abstract}

\section{Radiological Monitoring}

Radiological effluent monitoring results are a major component in determining compliance with applicable dose standards. SRS management philosophy ensures that potential exposures to members of the public and to onsite workers are kept as far below regulatory standards as is reasonably achievable. This philosophy is known as the "as low as reasonably achievable" (ALARA) concept.

SRS airborne and liquid effluents that potentially contain radionuclides are monitored at their points of discharge by a combination of direct measurement and/or sample extraction and analysis. Each operating facility maintains ownership of, and is responsible for, its radiological effluents.

Unspecified alpha and beta releases (the measured gross activity minus the identified individual radionuclides) in airborne and liquid releases are large contributors - on a percentage basis - to offsite doses, especially for the airborne

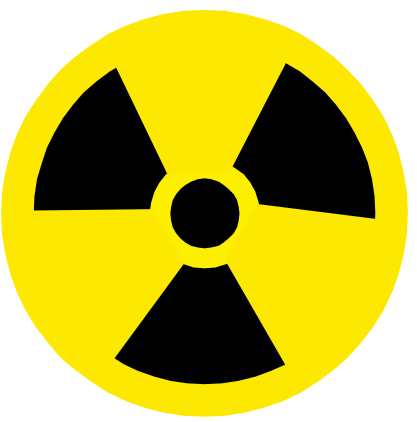
pathway from diffuse and fugitive releases (see definitions below).

The unspecified alpha and beta releases are listed separately in the effluent release tables. They conservatively include naturally occurring radionuclides such as uranium, thorium, and potassium-40, as well as small amounts of unidentified manmade radionuclides. For dose calculations, the unspecified alpha releases were assigned the plutonium-239 dose factor, and the unspecified beta releases were assigned the strontium-90 dose factor (chapter 6, "Potential Radiation Doses"). 


\section{Airborne Emissions}

Process area stacks that release, or have the potential to release, radioactive materials are monitored continuously by applicable online monitoring and/or sampling systems [SRS EM Program, 2001].

Depending on the processes involved, discharge stacks also may be monitored with "realtime" instrumentation to determine instantaneous and cumulative atmospheric releases to the environment. Tritium is one of the radionuclides monitored with continuous real-time instrumentation.

The following effluent sampling and monitoring changes were made during 2006:

- During October, 294-F-the older and more contaminated of F-Area's two sandfilters - was taken out of service. This is expected to significantly reduce sandfilter radioactive discharges from F-Area in 2007. Specific results of this action will be reported in the SRS Environmental Report for 2007.

- Weekly sampling was added at the Tritium Extraction Facility.

\section{Diffuse and Fugitive Sources}

Estimates of radionuclide releases from unmonitored diffuse and fugitive sources are calculated on an annual basis and are included in the SRS radioactive release totals. A diffuse source is defined as an area source, such as a pond or disposal area. A fugitive source is defined as an undesignated localized source, such as an open tank or naturally ventilated building.

Diffuse and fugitive releases are calculated using the U.S. Environmental Protection Agency's (EPA's) recommended methods [EPA, 2002]. Because these methods are conservative, they generally lead to overestimates of actual emissions. Though these releases are not monitored at their source, onsite and offsite environmental monitoring stations are in place to quantify unexpectedly large diffuse and fugitive releases (see chapter 5, "Environmental Surveillance").

\section{Monitoring Results Summary}

The total amount of radioactive material released to the environment is quantified by using data obtained from continuously monitored airborne effluent release points and estimates of diffuse and fugitive sources.

Tritium Tritium in elemental and oxide forms accounted for more than 99 percent of the total radioactivity released to the atmosphere from SRS operations. During 2006, about $34,600 \mathrm{Ci}$ of tritium were released from SRS, compared to about 40,800 Ci in 2005. Most of the releases came from the site's tritium facilities.

During the past 10 years, because of changes in the site's missions and the beginning of operations at the Replacement Tritium Facility, the amount of tritium released from SRS has fluctuated but has remained less than 100,000 Ci per year (figure 4-1). 


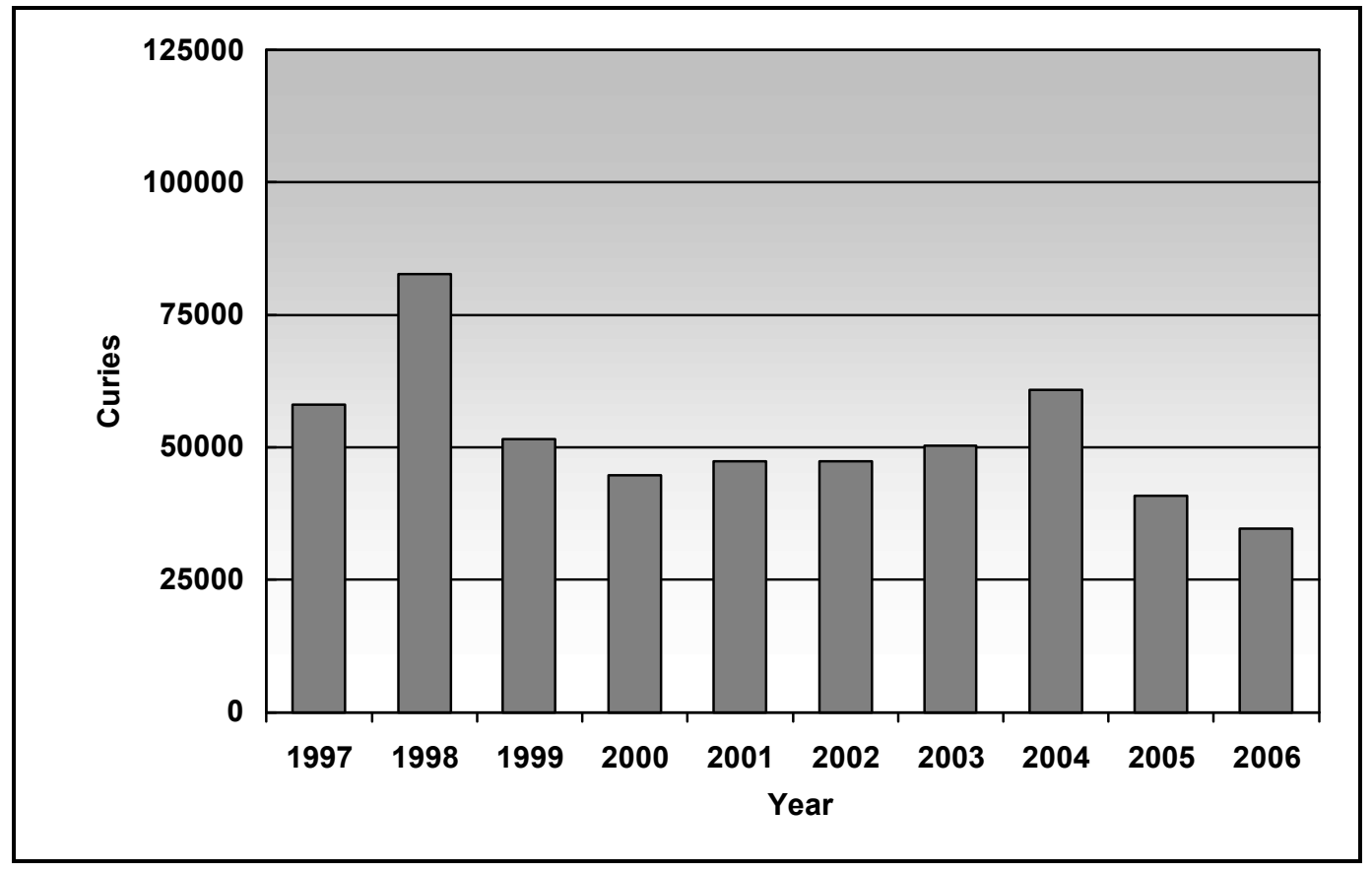

Figure 4-1 Ten-Year History of SRS Annual Atmospheric Tritium Releases

\section{Comparison of Average Concentrations in Airborne Emissions to DOE Derived} Concentration Guides Average concentrations of radionuclides in airborne emissions are calculated by dividing the amount of each radionuclide released annually from each stack by the respective yearly stack-flow volumes. These average concentrations then can be compared to the DOE derived concentration guides (DCGs) in DOE Order 5400.5, "Radiation Protection of the Public and the Environment," as a screening method to determine if existing effluent treatment systems are proper and effective. The 2006 atmospheric effluent annual-average concentrations, their comparisons against the DOE DCGs, and the quantities of radionuclides released are provided, by discharge point, on the $\mathrm{CD}$ accompanying this report.

DCGs are used as reference concentrations for conducting environmental protection programs at all DOE sites. DCGs are applicable at the point of discharge (prior to dilution or dispersion) under conditions of continuous exposure.

Most of the SRS radiological stacks/facilities release small quantities of radionuclides at concentrations below the DOE DCGs. However, tritium (in the oxide form) from the reactor (K-Area and L-Area main stacks and L-Area disassembly basin) and tritium facilities was emitted in 2006 at concentration levels above the DCGs. Plutonium-238 also exceeded the DCGs at the 291-F main stack. The offsite dose from all atmospheric releases, however, remained well below the DOE and EPA annual atmospheric pathway dose standard of $10 \mathrm{mrem}(0.1 \mathrm{mSv})$, as discussed in chapter 6 . 


\section{Liquid Discharges}

Each process area liquid effluent discharge point that releases, or has potential to release, radioactive materials is sampled routinely and analyzed for radioactivity [SRS EM Program, 2001].

Depending on the processes involved, liquid effluents also may be monitored with realtime instrumentation to ensure that instantaneous releases stay within established limits. Because the instruments have limited detection sensitivity, online monitoring systems are not used to quantify SRS liquid radioactive releases at their current low levels. Instead, samples are collected for more sensitive laboratory analysis.

\section{Monitoring Results Summary}

Data from continuously monitored liquid effluent discharge points are used in conjunction with site seepage basin and Solid Waste Disposal Facility (SWDF) migration release estimates to quantify the total radioactive material released to the Savannah River from SRS operations. SRS liquid radioactive releases for 2006 are shown by source on the CD accompanying this report. These data are a major component in the determination of offsite dose consequences from SRS operations.

Direct Discharges of Liquid Effluent Direct discharges of liquid effluents are quantified at the point of release to the receiving stream, prior to dilution by the stream. The release totals are based on measured concentrations and flow rates.

Tritium accounts for nearly all the radioactivity discharged in SRS liquid effluents. The total amount of tritium released directly from process areas - i.e., reactor, separations, Effluent Treatment Facility (ETF) - to site streams during 2006 was $214 \mathrm{Ci}$, which was 34 percent less than the 2005 total of $326 \mathrm{Ci}$. This decrease was because ETF continued to process wastewater with less tritium in it than in previous years.

Operations at D-Area and TNX were discontinued in 2000 and 2001, respectively. A-Area releases represent only a small percentage of the total direct releases of tritium to site streams. The reactor area releases include the overflows from PAR Pond and L Lake.

Direct releases of tritium to site streams for the years 1997-2006 are shown in figure 4-2. The migration and transport of radionuclides from site seepage basins and the SWDF are discussed in chapter 5 .

\section{Comparison of Average Concentrations in Liquid Releases to DOE Derived}

Concentration Guides In addition to dose standards, DOE Order 5400.5 imposes other control considerations on liquid releases. These considerations are applicable to direct discharges but not to seepage basin and SWDF migration discharges. The DOE order lists DCG values for most radionuclides.

DCGs are applicable at the point of discharge from the effluent conduit to the environment (prior to dilution or dispersion). According to DOE Order 5400.5, exceedance of the DCGs at any discharge point may require an investigation of "best available technology" waste treatment for the liquid effluents. Tritium in liquid effluents is specifically excluded from 


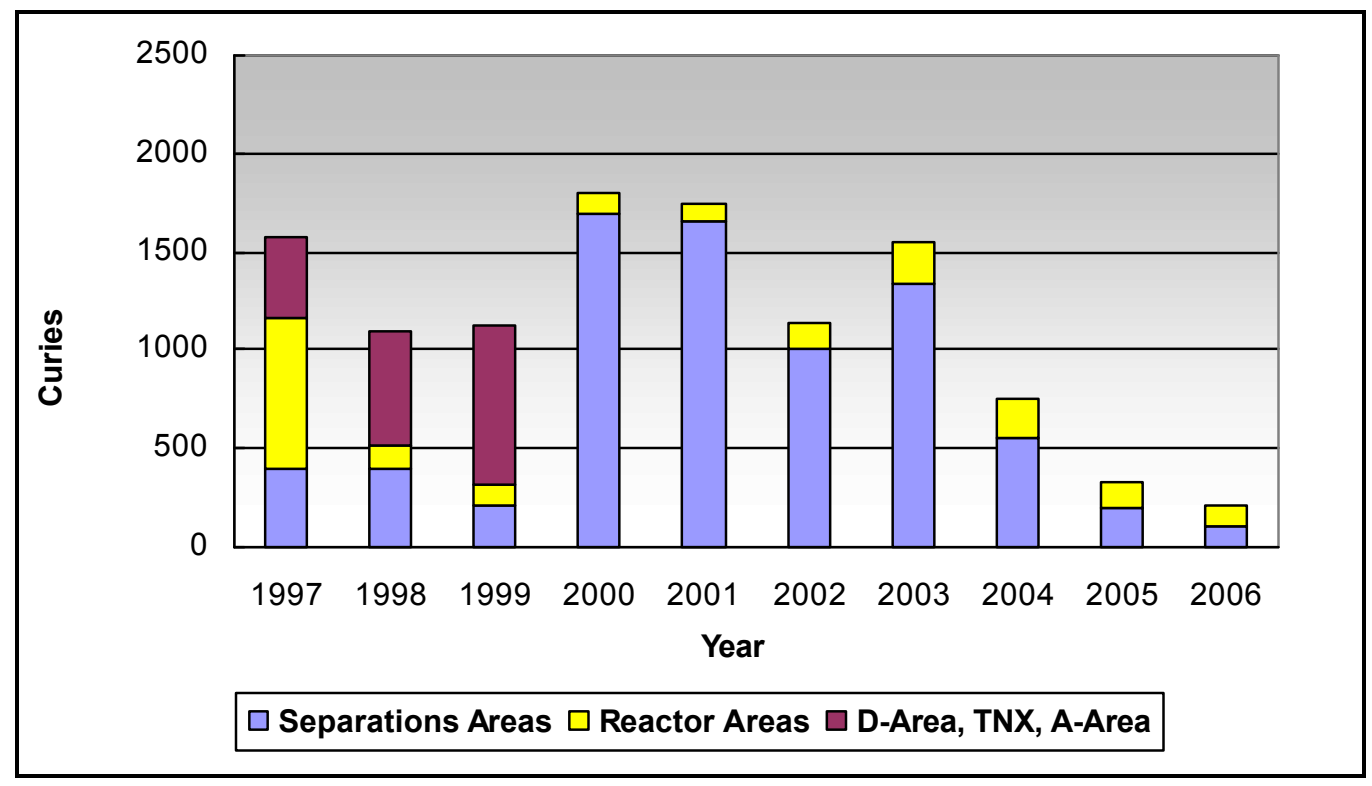

Figure 4-2 Ten-Year History of Direct Releases of Tritium to SRS Streams

"best available technology" requirements; however, it is not excluded from other ALARA considerations. DOE DCG compliance is demonstrated when the sum of the fractional DCG values for all radionuclides detectable in the effluent is less than 1.00, based on consecutive 12-month-average concentrations. The 2006 liquid effluent annual-average concentrations, their comparisons against the DOE DCGs, and the quantities of radionuclides released are provided, by discharge point, on the $\mathrm{CD}$ accompanying this report.

The data show that the U3R-2A ETF outfall at the Road C discharge point exceeded the DCG guide for 12-month-average tritium concentrations again during 2006. However, as noted previously, DOE Order 5400.5 specifically exempts tritium from "best available technology" waste treatment investigation requirements. This is because there is no practical technology available for removing tritium from dilute liquid waste streams. No other discharge points exceeded the DOE DCGs during 2006.

\section{Nonradiological Monitoring}

\section{Airborne Emissions}

The South Carolina Department of Health and Environmental Control (SCDHEC) regulates both radioactive and nonradioactive criteria and toxic air pollutant emissions from SRS sources. Each source of air emissions is permitted or exempted by SCDHEC on the SRS Part 70 Air Quality Permit (issued in 2003), with specific limitations and monitoring requirements identified. This section will cover only nonradioactive emissions.

The bases for the limitations and monitoring requirements specified in the Part 70 Air Quality Permit are outlined in various South Carolina and federal air pollution control regulations and standards. Many of the applicable standards are source dependent, i.e., 
applicable to certain types of industry, processes, or equipment. However, some standards govern all sources for criteria pollutants, toxic air pollutants, and ambient air quality. Air pollution control regulations and standards applicable to SRS sources are discussed briefly in appendix A, "Applicable Guidelines, Standards, and Regulations," of this report. The SCDHEC air standards for toxic air pollutants can be found at http://www.scdhec.net/baq on the Internet.

\section{Description of Monitoring Program}

Major nonradiological emissions of concern from stacks at SRS facilities include sulfur dioxide, carbon monoxide, oxides of nitrogen, particulate matter smaller than 10 microns, volatile organic compounds (VOCs), and toxic air pollutants. With the issuance of the new Part 70 Air Quality Permit, SRS has several continuous and periodic monitoring requirements; only the most significant are discussed below.

The primary method of source monitoring at SRS is the annual air emissions inventory. Actual emissions from SRS sources are determined during this inventory from standard calculations using source operating parameters, such as hours of operation, process throughput, and emission factors provided in the EPA "Compilation of Air Pollution Emission Factors," AP-42. Many of the processes at SRS, however, are unique sources requiring nonstandard, complex calculations. The hourly and total actual annual emissions for each source then can be compared against their respective permit limitations.

At the SRS A-Area Powerhouse, airborne emission specialists under contract to SRS perform stack compliance tests every two years for each boiler. The tests include sampling of the boiler exhaust gases to determine particulate matter, sulfur dioxide, and visible opacity emissions. The permit also requires a weekly sample and laboratory analysis of coal for sulfur content and, a daily visible-emissions inspection to verify compliance with opacity standards.

For the package steam generating boilers in K-Area, fuel oil-fired water heaters in B-Area, and diesel-powered equipment, compliance with sulfur dioxide standards is determined by analysis of the fuel oil purchased from the offsite vendor. Sulfur content of the fuel oil must be below 0.5 percent. This must be certified by the fuel supply vendor and reported to SCDHEC semiannually.

Monitoring of SRS diesel-powered equipment consists of tracking fuel oil consumption monthly and calculating a 12-month rolling total for determining permit compliance with a site consumption limit.

SRS has several soil vapor extraction units and two air strippers that are sources of toxic air pollutants and VOCs. These units must be sampled monthly for VOC concentrations, and the total VOC emissions must be calculated for comparison against a 12-month rolling limit. The VOC emissions then are reported to SCDHEC on a quarterly basis.

Several SRS sources have pollutant control devices - such as multiclone dust collectors, baghouse dust collectors, or condensers - whose parameters must be monitored continuously or whenever the system is operated. The operating parameters must be recorded and compared against specific operating ranges. 
Table 4-1

SRS Estimated Criteria Pollutant Air Emissions, 2003-2005

\begin{tabular}{|c|c|c|c|}
\hline \multirow[t]{2}{*}{ Pollutant Name } & \multicolumn{3}{|c|}{ Actual Emissions (Tons/Year) } \\
\hline & 2003 & 2004 & 2005 \\
\hline Sulfur dioxide $\left(\mathrm{SO}_{\mathrm{x}}\right)$ & $5.36 \mathrm{E}+02$ & $2.15 E+03$ & $6.97 \mathrm{E}+03$ \\
\hline Total particulate matter (PM) & $3.02 \mathrm{E}+02$ & $4.89 \mathrm{E}+02$ & $9.28 \mathrm{E}+02$ \\
\hline Particulate matter <10 microns $\left(\mathrm{PM}_{10}\right)$ & $1.18 E+02$ & $1.89 E+02$ & $5.71 \mathrm{E}+02$ \\
\hline Particulate matter <2.5 microns $\left(\mathrm{PM}_{2.5}\right)$ & a & a & $4.77 \mathrm{E}+02$ \\
\hline Carbon monoxide $(\mathrm{CO})$ & $2.29 \mathrm{E}+03$ & $9.82 \mathrm{E}+02$ & $1.03 E+03$ \\
\hline Ozone (volatile organic compounds) & $9.33 \mathrm{E}+01$ & $5.44 \mathrm{E}+02$ & $5.48 \mathrm{E}+02$ \\
\hline Gaseous fluorides (as hydrogen fluoride) & 1.14E-01 & 1.39E-01 & $1.43 \mathrm{E}-01$ \\
\hline Nitrogen dioxide $\left(\mathrm{NO}_{\mathrm{x}}\right)$ & $2.66 \mathrm{E}+02$ & $4.24 \mathrm{E}+03$ & $7.18 \mathrm{E}+03$ \\
\hline Lead (lead components) & $5.58 \mathrm{E}-01$ & $1.58 \mathrm{E}-01$ & $1.74 \mathrm{E}-01$ \\
\hline
\end{tabular}

Compliance by all SRS permitted sources is evaluated during annual compliance inspections by the local SCDHEC district air manager. The inspections include a review of each permit condition, i.e., daily monitoring readings, equipment calibrations, control device inspections, etc.

\section{Monitoring Results Summary}

In 2006, operating data were compiled and emissions calculated for 2005 operations for all site air emission sources. Because this process, which begins in January, requires up to 6 months to complete, this report provides a comprehensive examination of total 2005 emissions, with only limited discussion of available 2006 monitoring results for specific sources.

The 2005 total criteria air pollutant emission estimates for all SRS permitted sources, as determined by the air emissions inventory conducted in 2006, are provided in table 4-1 and on the CD accompanying this report. A review of the calculated emissions for each source for calendar year 2005 determined that SRS sources had operated in compliance with permitted emission rates. Some toxic air pollutants (e.g., benzene) regulated by SCDHEC also are, by nature, VOCs. As such, the total for VOCs in table 4-1 includes toxic air pollutant emissions.

Three power plants with nine overfeed stoker-fed coal-fired boilers are maintained by Washington Savannah River Company (WSRC) at SRS. The location, number of boilers, and capacity of each boiler for these plants are listed in table 4-2. A-Area boiler No. 2 was stack-tested in 2006 (February). At that time, the boiler's particulate matter, sulfur dioxide, and visible emissions were found to be in compliance with its permitted limit. Results from the test are shown in table 4-3. The four D-Area Powerhouse boilers were stack tested in 2006; these results also are shown in table 4-3. The three H-Area Powerhouse boilers have not operated since 2000-2001. 
Table 4-2

SRS Power Plant Boiler Capacities

\begin{tabular}{lcc}
\hline Location & Number of Boilers & Capacity (Btu/hr) \\
\hline A-Area & 2 & $71.7 \mathrm{E}+06$ \\
H-Area & 3 & $71.1 \mathrm{E}+06$ \\
D-Area & 4 & $396.0 \mathrm{E}+06$ \\
\hline
\end{tabular}

On February 1, 2006, WSRC assumed operational responsibility for the D-Area

Powerhouse (484-D) from South Carolina Electric and Gas (SCE\&G), which had operated the facility for DOE under a separate contract since 1995. The D-Area Powerhouse has four coal-fired boilers, and each is on an annual stack test schedule as required by the Part 70 Air Quality Permit. The results of each stack test are shown in table 4-3.

SRS also has two package steam generating boilers in K-Area fired by No. 2 fuel oil. The percent of sulfur in the fuel oil must be vendor certified semiannually to ensure that the fuel meets permit specifications; the certification was documented twice during 2006.

\begin{tabular}{|c|c|c|c|}
\hline \multicolumn{4}{|c|}{$\begin{array}{l}\text { Table 4-3 } \\
\text { Boiler Stack Test Results }\end{array}$} \\
\hline \multirow{2}{*}{ Boiler } & \multirow{2}{*}{ Pollutant } & \multicolumn{2}{|c|}{ Emission Rates } \\
\hline & & Ib/106 Btu & $\mathrm{Ib} / \mathrm{hr}$ \\
\hline \multirow[t]{3}{*}{ A \#1 } & Particulates $^{a}$ & 0.248 & 17.88 \\
\hline & Sulfur dioxide ${ }^{a}$ & 1.814 & 130.9 \\
\hline & Opacity $^{c}$ & Avg. $15.3 \%$ & \\
\hline \multirow[t]{3}{*}{$\mathrm{D \# 1}$} & Particulates $^{a}$ & 0.080 & 34.281 \\
\hline & Sulfur dioxide ${ }^{a}$ & 1.003 & $N C^{b}$ \\
\hline & Opacity $^{c}$ & Avg. $7.0 \%$ & \\
\hline \multirow[t]{3}{*}{$\mathrm{D \# 2}$} & Particulates $^{a}$ & 0.146 & 51.21 \\
\hline & Sulfur dioxide ${ }^{a}$ & 1.065 & $N C^{b}$ \\
\hline & Opacity $^{c}$ & Avg. $8.1 \%$ & \\
\hline \multirow[t]{3}{*}{ D\#3 } & Particulates $^{a}$ & 0.122 & 53.42 \\
\hline & Sulfur dioxide ${ }^{a}$ & 1.185 & $N C^{b}$ \\
\hline & Opacity $^{c}$ & Avg. $5.5 \%$ & \\
\hline \multirow[t]{3}{*}{ D\#4 } & Particulates $^{a}$ & 0.037 & 18.53 \\
\hline & Sulfur dioxide ${ }^{a}$ & 0.952 & $N C^{b}$ \\
\hline & Opacity $^{c}$ & Avg. $10 \%$ & \\
\hline $\begin{array}{l}{ }^{a} \text { The cor } \\
{ }^{b} \text { Not cal } \\
{ }^{c} \text { Opacity }\end{array}$ & $6 \mathrm{lb} /$ million Btu for & ion Btu for sulft & \\
\hline
\end{tabular}


The total diesel fuel consumption for portable air compressors, generators, emergency cooling water pumps, and fire water pumps was found to be well below the SRS limit for the entire reporting period. As reported to SCDHEC during 2006, the calculated annual VOC emissions were well below the permit limit for each unit.

In 2006, the annual air compliance inspection was conducted by the SCDHEC district air manager. During the inspection, all SRS permitted sources were found to be in compliance with their respective permit conditions and limits, and all required reports were determined to have been submitted to SCDHEC within specified time limits.

\section{Ambient Air Quality}

Under existing regulations, SRS is not required to conduct onsite monitoring for ambient air quality; however, the site is required to show compliance with various air quality standards. To accomplish this, air dispersion modeling was conducted during 2006 for new emission sources or modified sources as part of the sources' construction permitting process. The modeling analysis showed that SRS air emission sources were in compliance with applicable regulations. Additional information about ambient-air-quality regulations at the site can be found in appendix A of this report.

\section{Liquid Discharges}

\section{Description of Monitoring Program}

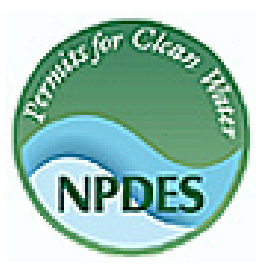

SRS monitors nonradioactive liquid discharges to surface waters through the National Pollutant Discharge Elimination System (NPDES), as mandated by the Clean Water Act. As required by EPA and SCDHEC, SRS has NPDES permits in place for discharges to the waters of the United States and South Carolina. These permits establish the specific sites to be monitored, parameters to be tested, and monitoring frequency - as well as analytical, reporting, and collection methods. Detailed requirements for each permitted discharge point can be found in the individual permits, which are available to the public through SCDHEC's Freedom of Information office at 803-734-5376.

In 2006, SRS discharged water into site streams and the Savannah River under three NPDES permits: two for industrial wastewater (SC0000175 and SC0047431) and one for stormwater runoff-SCR000000 (industrial discharge). A fourth permit, SCR100000, does not require sampling unless requested by SCDHEC to address specific discharge issues at a given construction site; SCDHEC did not request such sampling in 2006.

During 2006, all issues generated during a public comment period for draft permit SCR100000 were resolved, and the new permit became effective September 1. In anticipation of the announced effective date for this permit, SRS already had implemented the new requirements into the site construction stormwater program.

Permit SC0047431 became a DOE/SRS responsibility after the February 1 transfer of DArea Powerhouse operations to WSRC.

Under Permit SC0000175, NPDES outfall H-04 flows were diverted into the H-Area cooling water system, and the outfall was removed from the permit effective December 1. 
SRS submitted a permit application in 2006 for each of nine individual stormwater outfalls for which the average of any four consecutive analyses exceeded the proposed EPA Multisector General Permit benchmarks. Sampling results obtained in 2004 and 2005 were used to identify the nine outfalls from the 39 outfalls covered by the General Permit (SCR000000).

Permit ND0072125 is a "no discharge" water pollution control land application permit that regulates sludge application and related sampling at onsite sanitary wastewater treatment facilities.

NPDES samples are collected in the field according to 40 CFR 136, the federal document that lists specific sample collection, preservation, and analytical methods acceptable for the type of pollutant to be analyzed. Chain-of-custody procedures are followed after collection and during transport to the analytical laboratory. The samples then are accepted by the laboratory and analyzed according to procedures listed in 40 CFR 136 for the parameters required by the permit.

\section{Monitoring Results Summary}

SRS reports industrial wastewater analytical results to SCDHEC through a monthly discharge monitoring report (EPA Form 3320-1). Results from only three of the 4,950 sample analyses (including flow measurements) performed during 2006 exceeded permit limits - a 99.94-percent compliance rate, which is higher than the DOE-mandated 98percent rate. The three exceedances, which occurred at outfalls F-08 and G-10, are explained in table 4-4. Complete NPDES data can be found on the CD accompanying this report.

All "annual" stormwater outfalls at SRS were sampled at least once in 2006; supplementary parameters were added to some of these outfalls. The nine individual stormwater outfalls referred to in the previous section also were sampled during 2006. Several stormwater outfalls exceeded EPA benchmarks for iron, copper, zinc, and other trace metals. Nine outfalls had problems that prompted SCDHEC to request that SRS submit a permit application for each of those outfalls. Ten outfalls exceeded EPA benchmarks but were not of sufficient concern to require individual permits. These 10 outfalls will require some best management practices to meet EPA benchmarks. The remaining outfalls required no action. Complete stormwater data can be found on the CD accompanying this report.

Under Permit ND0072125, approximately 69 cubic yards of dewatered sludge were applied during the first quarter of 2006 to SRS's land application site - a forested area located near the intersection of Burma Road and Road 3. Approximately 54 cubic yards were applied to rows 4-12 from February 27 through March 2, and approximately 15 cubic yards were applied to rows 1-3 March 23. No additional applications were made the remainder of the year.

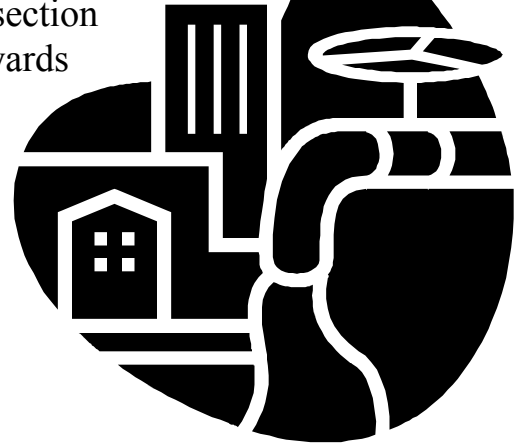


Table 4-4

2006 Exceedances of SCDHEC-Issued NPDES Permit Liquid Discharge Limits at SRS ${ }^{a}$

\begin{tabular}{|c|c|c|c|c|c|}
\hline Department/Area & Outfall & Date(s) & Parameter & $\begin{array}{l}\text { Possible } \\
\text { Cause(s) }\end{array}$ & $\begin{array}{l}\text { Corrective } \\
\text { Action(s) }\end{array}$ \\
\hline ISD/CSWTF & $\mathrm{G}-10$ & $\begin{array}{l}\text { March 2, } \\
\text { March } 10\end{array}$ & $\begin{array}{l}\text { Ammonia } \\
\text { (monthly average) } \\
\text { Value: } 6.4 \mathrm{mg} / \mathrm{l} \\
\text { Limit: } 3.6 \mathrm{mg} / \mathrm{l}\end{array}$ & $\begin{array}{l}\text { One of two } \\
\text { oxidation } \\
\text { ditches } \\
\text { removed from } \\
\text { service for } \\
\text { valve repairs; } \\
\text { ditch left } \\
\text { offline after } \\
\text { repairs }\end{array}$ & $\begin{array}{l}\text { Second ditch } \\
\text { placed back } \\
\text { in service; } \\
\text { subsequent } \\
\text { samples } \\
\text { within permit } \\
\text { limits }\end{array}$ \\
\hline ISD/CSWTF & G-10 & March 10 & $\begin{array}{l}\text { Ammonia } \\
\text { (daily maximum) } \\
\text { Value: } 7.6 \mathrm{mg} / \mathrm{l} \\
\text { Limit: } 7.2 \mathrm{mg} / \mathrm{l}\end{array}$ & $\begin{array}{l}\text { Same as } \\
\text { above }\end{array}$ & $\begin{array}{l}\text { Same as } \\
\text { above }\end{array}$ \\
\hline Closure/F-Canyon & $\mathrm{F}-08$ & $\begin{array}{l}\text { August } 2 \text {, } \\
22,23,24 \\
25,28,29 \\
30,31 ; \\
\text { Sept. } 1^{b}\end{array}$ & $\begin{array}{l}\text { Lead } \\
\text { (monthly average) } \\
\text { Value: } 0.0132 \mathrm{mg} / \mathrm{l} \\
\text { Limit: } 0.009 \mathrm{mg} / \mathrm{l}\end{array}$ & $\begin{array}{l}\text { Startup of a } \\
\text { deactivated } \\
\text { instrument air } \\
\text { system }\end{array}$ & $\begin{array}{l}\text { System } \\
\text { removed } \\
\text { from service; } \\
\text { other } \\
\text { possibilities } \\
\text { still under } \\
\text { investigation }\end{array}$ \\
\hline \multicolumn{6}{|c|}{$\begin{array}{l}\text { a The DOE-mandated NPDES compliance rate is } 98 \text { percent; SRS's compliance rate for } 2006 \text { was } 99.94 \\
\text { percent. } \\
\text { b The September } 1 \text { sample was a 24-hour composite begun August } 31 \text {. Reporting protocol requires that any } \\
\text { sample started within a given month be reported in that month's discharge monitoring report. }\end{array}$} \\
\hline
\end{tabular}





\title{
Environmental Surveillance
}

\author{
Pete Fledderman, Donald Padgett, and Monte Steedley \\ Environmental Services Section \\ Timothy Jannik \\ Savannah River National Laboratory
}

$\mathrm{E}$ nvironmental surveillance at the Savannah River Site (SRS) is designed to survey and quantify any effects that routine and nonroutine operations could have on the site and on the surrounding area and population. Site surveillance activities are divided into radiological and nonradiological programs.

As part of the radiological surveillance program, routine surveillance of all radiation exposure pathways is performed on all environmental media that could lead to a measurable annual dose at and beyond the site boundary.

Nonradioactive environmental surveillance at SRS involves the sampling and analysis of surface water, drinking water, sediment, groundwater, and fish. Results from the analyses of surface water, drinking water, sediment, and fish are discussed in this chapter. A description of the groundwater monitoring program analysis results can be found in chapter 7, "Groundwater."

The Environmental Services Section's Environmental Permitting and Monitoring (EPM) group and the Savannah River National Laboratory (SRNL) perform surveillance activities for SRS. The Savannah River also is monitored by other groups, including the South Carolina Department of Health and Environmental Control (SCDHEC), the Georgia Department of Natural Resources, and the Academy of Natural Sciences (ANS).

A complete description of the EPM surveillance program, including sample collection and analytical procedures, can be found in section 1105 of the Savannah River Site Environmental Monitoring Section Plans and Procedures, WSRC-3Q1-2 (SRS EM Program). Brief summaries of analytical results are presented in this chapter; complete data sets can be found in tables on the $\mathrm{CD}$ accompanying this report.

\section{Radiological Surveillance}

\section{Air}

\section{Description of Surveillance Program}

EPM maintains a network of 15 sampling stations in and around SRS to monitor the concentration of tritium and radioactive particulate materials in the air. 


\section{Surveillance Results Summary}

Except for tritium, specific radionuclides were not routinely detectable at the site perimeter. Both onsite and offsite activity concentrations were similar to levels observed in previous years.

Average gross alpha and gross beta results were slightly higher in 2006 than in 2005; however, they are consistent with historical results, which demonstrate long-term variability.

Only one sample contained detectable manmade gamma-emitting radionuclides (Cs-137) in 2006. This is consistent with historical results, which indicate only a small number of air samples with detectable activity.

During 2006, detectable levels of uranium-234 were observed in all air samples; uranium238 was observed in most of these samples, and uranium-235 was observed in one sample, from Savannah, Georgia. These results are similar to those observed in 2005.

Concentrations of the uranium isotopes were slightly lower than, but similar to, those observed in 2005. Aside from uranium, alpha-emitting radionuclide activity was observed in six samples from five locations. Americium-241 was detected at four locations on the site perimeter and one 25-mile location, while plutonium-238 was detected at one site perimeter location. Generally, these concentrations were consistent with historical results. All isotopes at the remaining locations were below detection levels. As observed in previous years, none of the samples showed strontium-89,90 above their minimum detectable concentration (MDC).

A self-assessment — conducted during the summer of 2006 - revealed an error in the calculation of tritium-in-air results, with the potential for under-reporting actual concentrations. This error was corrected in the software and the results were recalculated. However, the expected increase in tritium concentration was not observed, except at the Burial Ground North (BGN) location. In large part, this is the result of decreased atmospheric releases (see chapter 4, "Effluent Monitoring").

With the exception of the BGN location, tritium-in-air results for 2006 were similar tobut generally lower than - those observed in 2005. Tritium was detected at every sampling location, although not every sample from a particular location had detectable tritium. As in previous years, the BGN location showed average and maximum concentrations significantly higher than those observed at other locations. This was expected because of its proximity to SRS's tritium facilities, which are near the center of the site. Consistent with the SRS source term, tritium concentrations generally decrease with increasing distance from the tritium facilities.

\section{Rainwater}

\section{Description of Surveillance Program}

SRS maintains a network of 15 rainwater sampling sites as part of the air surveillance program. These stations are used to measure deposition of radioactive materials. 


\section{Surveillance Results Summary}

Gamma-Emitting Radionuclides No detectable manmade gamma-emitting radionuclides were observed in rainwater samples in 2006.

Gross alpha and gross beta results from 2006 were consistent with those of 2005. In 2006, both the gross alpha and gross beta results generally were slightly lower than those of 2005. However, no long-term increasing or decreasing trend was evident, which implies that the observed values are natural background and does not indicate any contribution directly attributable to SRS.

Detectable levels of uranium-234 and uranium-238 were present in most samples. Elevated results were observed at the D-Area and BGN locations. D\&D activities in the immediate vicinity of these sampling sites resulted in the movement of large amounts of soil and the subsequent formation of increased airborne particulates (dust). It is believed that this phenomenon is responsible for the observed increase. All locations showed detectable americium-241 (overall, 46 percent of the samples) and plutonium-238 (overall, 19 percent of the samples). All other actinides, as well as strontium-89,90, either were below detection levels or were present in only a small number of samples in 2006.

As in previous years, tritium-in-rain values were highest near the center of the site. This is consistent with the H-Area effluent release points that routinely release tritium. Tritium was detected at every sampling location, although not every sample from a particular location had detectable tritium. As with tritium in air, concentrations generally decreased as distance from the effluent release point increased.

\section{Gamma Radiation}

\section{Description of Surveillance Program}

Ambient gamma exposure rates in and around SRS are monitored by a system of thermoluminescent dosimeters (TLDs).

\section{Surveillance Results Summary}

Exposures at all TLD monitoring locations show some variation based on normal site-tosite and year-to-year differences in the components of natural ambient gamma exposure levels. Exposure rates varied between 57 and 111 mrem per year.

In general, the 2006 ambient gamma radiation monitoring results indicated gamma exposure rates slightly lower than those observed at the same locations in 2005. However, these results generally are consistent with previously published historical results, and indicate that no significant difference in average exposure rates is observed between monitoring networks - except in the case of population centers. Exposure rates in population centers are slightly elevated compared to the other monitoring networks - as expected-because of factors such as buildings and roadways, which emit small amounts of radiation. 


\section{E-Area Stormwater Basins}

\section{Description of Surveillance Program}

Stormwater accumulating in the E-Area stormwater basins is monitored because of potential contamination.

\section{Surveillance Results Summary}

There are no active discharges to the E-Area stormwater basins. The primary contributor to the E-Area basins is rainwater runoff from the low-level-waste burial ground. Rain events did not supply enough water to the E-06 basin for sampling purposes in 2006. The highest E-Area basin mean tritium concentration was observed at E- -05 , and was approximately four times lower than in 2005; this decrease is the result of decreased influence from the southwest plume phytoremediation project. No detectable fission products were observed at any of the basins; likewise, most actinides were below detection. However, uranium234, uranium-238, and americium-241 were detected at some of the basins. Gross alpha and gross beta were detected at all basins in concentrations generally consistent with those of previous years.

\section{Site Streams}

\section{Description of Surveillance Program}

Continuous surveillance monitoring occurs downstream of several process areas to detect and quantify levels of radioactivity in effluents transported to the Savannah River.

\section{Surveillance Results Summary}

Demolition and construction activities continued to impact site stream surveillance locations in 2006. Sampling point U3R-F3, which was removed from service in 2005 because of construction activities at the MOX Fuel Fabrication Facility (MFFF), will be reestablished in 2007. In the interim, U3R sampling equipment located downstream of $\mathrm{U} 3 \mathrm{R}-\mathrm{F} 3$ tracked any releases that may have originated in the U3R-F3 drainage area. Releases to U3R-F3 were highly unlikely because the primary source to the outfall was deactivated in 2005 and, with exception of a remaining concrete pad, was demolished in early 2006.

Tritium, the predominant radionuclide detected above background levels in SRS streams, was observed at all stream locations in 2006 except the Upper Three Runs control point and site $\mathrm{X}-008$ near T-Area. Tritium concentrations in all site streams generally declined in 2006 except at Steel Creek, which remained stable.

No detectable concentrations of cobalt-60 were observed in any of the five major SRS streams. As expected, gross alpha and gross beta were observed in all streams, and were consistent with, but generally lower than, 2005 concentrations. Other nuclides were observed at locations throughout the site, consistent with the source of the material. Fission products generally were observed in Four Mile Creek; uranium generally was observed in the vicinity of T-Area; and uranium and other actinides generally were observed at the Central Sanitary Waste Treatment Facility. Some degree of year-to-year variation typically 


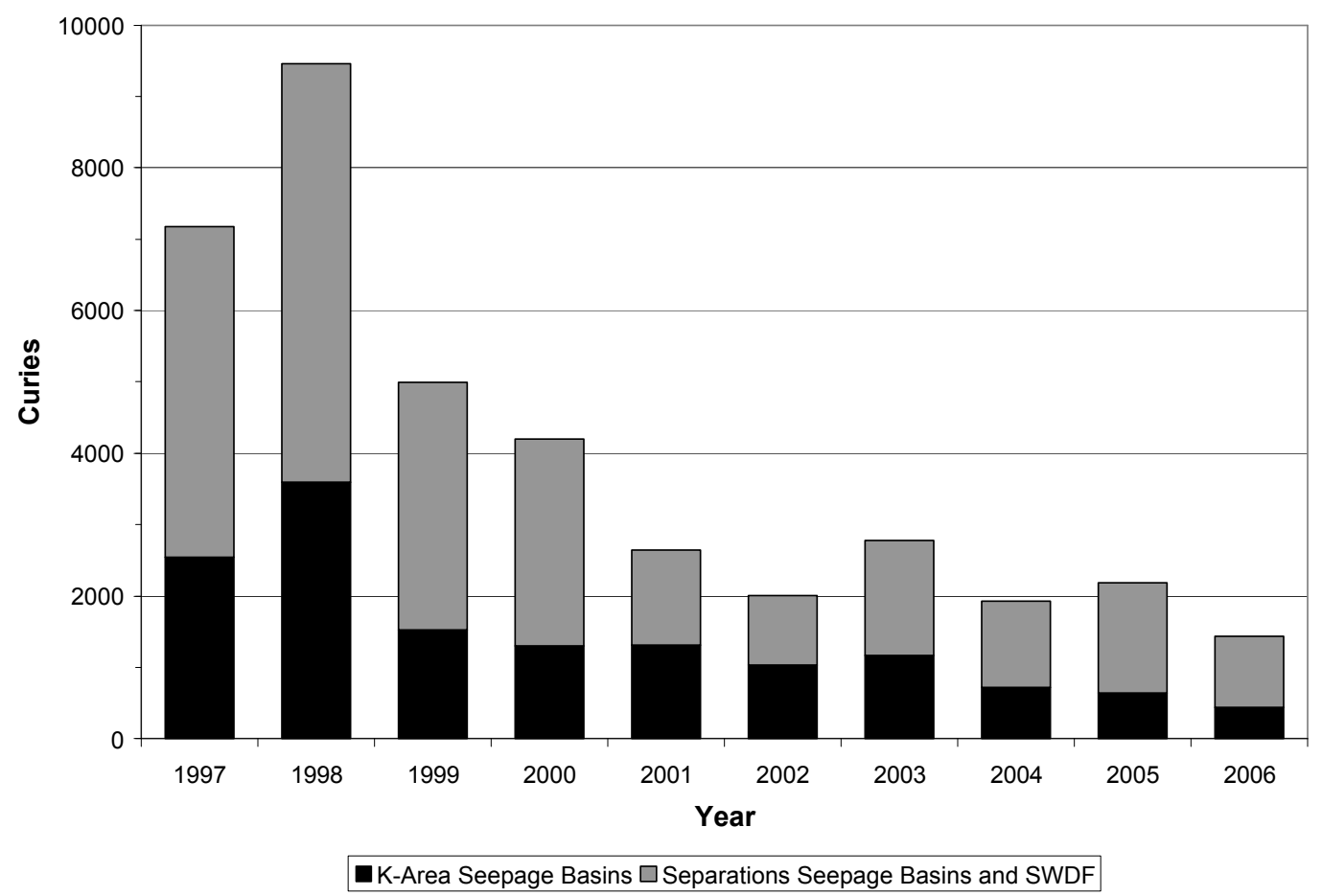

Figure 5-1 Tritium from SRS Seepage Basins and SWDF to Site Streams, 1997-2006

is observed in environmental media; however, no significant differences were observed between the 2005 and 2006 results.

\section{Seepage Basin and Solid Waste Disposal Facility Radionuclide Migration}

To incorporate the migration of radioactivity to site streams into total radioactive release quantities, EPM continued to monitor and quantify the migration of radioactivity from site seepage basins and the Solid Waste Disposal Facility (SWDF) in 2006 as part of its stream surveillance program. Tritium, strontium-89,90, technetium-99, iodine-129, and cesium137 were detected in migration releases.

Figure 5-1 is a graphical representation of releases of tritium via migration to site streams for the years 1997-2006. During 2006, the total quantity of tritium migrating from site seepage basins and SWDF was 1,644 Ci, compared to 2,180 Ci in 2005. This 25-percent decrease is attributed mainly to the completion in April 2006 of repair work on the Mixed Waste Management Facility Groundwater Retention Dam, which prevents contaminated shallow groundwater from reaching Four Mile Creek.

Radioactivity previously deposited in the F-Area and H-Area seepage basins and SWDF continues to migrate through the groundwater and to outcrop into Four Mile Creek and Upper Three Runs. Measured migration of tritium into Four Mile Creek in 2006 occurred as follows: 
- from F-Area seepage basins, $69.3 \mathrm{Ci}$ - an 89-percent decrease from the 2005 total of $630 \mathrm{Ci}$

- from H-Area seepage basin 4 and SWDF, $657 \mathrm{Ci}$ - an 11-percent increase from the 2005 total of $592 \mathrm{Ci}$

- from H-Area seepage basins 1, 2, and 3, $173 \mathrm{Ci}$-a 28-percent decrease from the 2005 total of $242 \mathrm{Ci}$

The measured migration from the north side of SWDF and the General Separations Area (GSA) into Upper Three Runs in 2006 was $94 \mathrm{Ci}$, a 25-percent increase from the 2005 total of $75 \mathrm{Ci}$. (The GSA is in the central part of SRS and contains all waste disposal facilities, chemical separations facilities, and associated high-level waste storage facilities, and numerous other sources of radioactive material.)

The total amount of strontium-89,90 entering Four Mile Creek from the GSA seepage basins and SWDF during 2006 was estimated to be $33.1 \mathrm{mCi}$. Migration releases of strontium-89,90 vary from year to year but have remained below $100 \mathrm{mCi}$ the past 5 years.

In addition, a total of $41.3 \mathrm{mCi}$ of cesium-137 was estimated to have migrated from the GSA seepage basins and SWDF in 2006. This 57-percent decrease from the 2005 total of $96.4 \mathrm{mCi}$ is attributed primarily to the previously discussed completion of repair work on the Mixed Waste Management Facility Groundwater Retention Dam.

In 2006, $6.38 \mathrm{mCi}$ of technetium-99 and $8.31 \mathrm{mCi}$ of iodine- 129 were estimated to have migrated into Four Mile Creek.

K-Area Drain Field and Seepage Basin Liquid purges from the K-Area disassembly basin were released to the K-Area seepage basin in 1959 and 1960. From 1960 until 1992, purges from the K-Area disassembly basin were discharged to a percolation field below the $\mathrm{K}$-Area retention basin. Tritium migration from the seepage basin and the percolation field is measured in Pen Branch. The 2006 migration total of $439 \mathrm{Ci}$ represents a 32-percent decrease from the $641 \mathrm{Ci}$ recorded in 2005.

C-Area, L-Area, and P-Area Seepage Basins Liquid purges from the C-Area, L-Area, and P-Area disassembly basins were released periodically to their respective seepage basins from the 1950s until 1970.

Migration releases from these basins no longer are quantified; however, they are accounted for in the stream transport totals.

\section{Transport of Actinides in Streams}

Because of their historically low levels, the actinides uranium, plutonium, americium, and curium no longer are quantified in SRS streams. However, the streams are sampled and analyzed annually for the presence of these actinides. The resulting concentrations are compared to those of previous years to identify any trends. Values for 2006 were consistent with historical data. 


\section{Savannah River}

\section{Description of Surveillance Program}

Continuous surveillance is performed along the Savannah River at points above and below SRS, and includes the point at which liquid discharges from Georgia Power Company's Vogtle Electric Generating Plant (VEGP) enter the river.

\section{Surveillance Results Summary}

Tritium is the predominant radionuclide detected above background levels in the Savannah River. The annual mean tritium concentration at RM-118.8 in 2006 was about 3 percent of the drinking water standard.

Detectable gross beta activity was observed at all river sampling locations, and was consistent with long-term gross beta levels in the river.

Detectable manmade radionuclides in Savannah River water were tritium, as indicated above, and uranium-234 (three samples), uranium-235 (two samples), and americium-241 (one sample).

\section{Tritium Transport in Streams}

Tritium is introduced into SRS streams and the Savannah River from former production areas on site. Because of the mobility of tritium in water and the quantity of the radionuclide released during the years of SRS operations, a tritium balance has been performed annually since 1960 . The balance is evaluated among the following alternative methods of calculation:

- tritium releases from effluent release points and calculated seepage basin and SWDF migration (direct releases)

- tritium transport in SRS streams and the last sampling point before entry into the Savannah River (stream transport)

- tritium transport in the Savannah River downriver of SRS after subtraction of any measured contribution above the site (river transport)

The combined tritium releases in 2006 (direct discharges and migration from seepage basins and SWDF) totaled 1,644 Ci, compared to 2,506 Ci in 2005.

The total tritium transport in SRS streams decreased from 2,378 $\mathrm{Ci}$ in 2005 to $1,391 \mathrm{Ci}$ in 2006.

The total tritium transport in the Savannah River for 2006 was 3,328 Ci, compared with the previous year's 4,480 Ci. Both VEGP and SRS contributed to these release values. Accounting for VEGP's contribution, SRS's calculated releases of tritium to the river in 2006 totaled $1,248 \mathrm{Ci}$. 


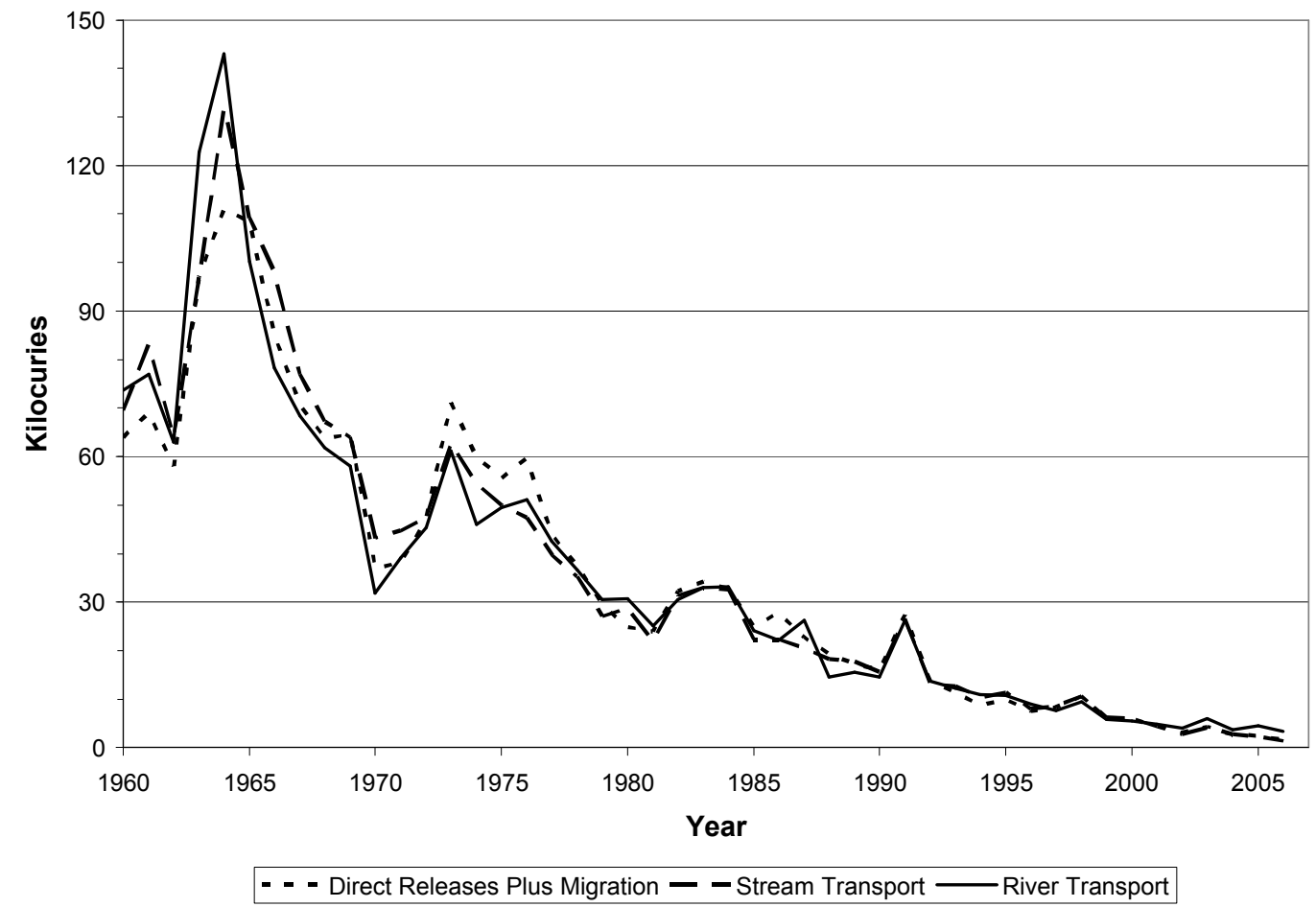

Figure 5-2 SRS Tritium Transport Summary, 1960-2006

SRS has maintained a tritium balance of direct releases plus migration, stream transport, and river transport since 1960 in an effort to account for and trend tritium releases in liquid effluents from the site. The general trend over time is attributable to (1) variations in tritium production at the site (production was discontinued in the late 1980s); (2) the implementation of effluent controls, such as seepage basins, beginning in the early 1960s; and (3) the continuing depletion and decay of the site's tritium inventory.

SRS tritium transport data for 1960-2006 are depicted in figure 5-2, which shows the history of direct releases, stream transport, and river transport, as determined by EPM.

EPM continued to assess the tritium flux in the Lower Three Runs system in 2006, as initially described in the SRS Environmental Report for 2004. As in the previous several years, a small but measurable amount of tritium from earlier EnergySolutions LLC (formerly Chem-Nuclear Systems) operations entered the stream system. The amount of the tritium is expected to continue a gradual decline. EPM and EnergySolutions will maintain a monitoring program for Lower Three Runs to evaluate this tritium migration.

\section{Domestic and Drinking Water}

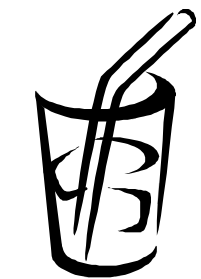

\section{Description of Surveillance Program}

EPM collected domestic and drinking water samples in 2006 from locations at SRS and at water treatment facilities that use Savannah River water. Potable water was analyzed at offsite treatment facilities to ensure that SRS operations did not adversely affect the water supply and to provide voluntary 
assurance that drinking water did not exceed EPA drinking water standards for radionuclides.

Onsite domestic water sampling consisted of quarterly grab samples at large treatment plants in A-Area, D-Area, and K-Area and annual grab samples at wells and small systems. Composite samples were collected monthly off site from

- the Beaufort-Jasper Water and Sewer Authority's Chelsea and Purrysburg Water Treatment Plants

- the City of Savannah Industrial and Domestic Water Supply Plant

- the North Augusta (South Carolina) Water Treatment Plant

\section{Surveillance Results Summary}

All domestic and drinking water samples collected by EPM were screened for gross alpha and gross beta concentrations to determine if activity levels warrant further analysis. No domestic water used for drinking purposes exceeded EPA's $1.50 \mathrm{E}+01-\mathrm{pCi} / \mathrm{L}$ alpha activity limit or $5.00 \mathrm{E}+01-\mathrm{pCi} / \mathrm{L}$ beta activity limit. Also, no onsite or offsite domestic or drinking water samples exceeded the $2.00 \mathrm{E}+04-\mathrm{pCi} / \mathrm{L}$ EPA tritium limit, and no domestic or drinking water samples exceeded the strontium 89,90 MDC.

No cobalt-60, cesium-137, uranium-235, plutonium-238, plutonium-239, or curium-244 was detected in any domestic or drinking water samples. Americium-241 was detected at nine locations, uranium-234 at 10 locations, and uranium-238 at five locations.

\section{Terrestrial Food Products}

\section{Description of Surveillance Program}

The terrestrial food products surveillance program consists of radiological analyses of food product samples typically found in the Central Savannah River Area (CSRA). These food products include meat (beef), fruit, and green vegetables (collards). Data from the food product surveillance program are not used to show direct compliance with any dose standard; however, the data can be used as required to verify dose models and determine environmental trends.

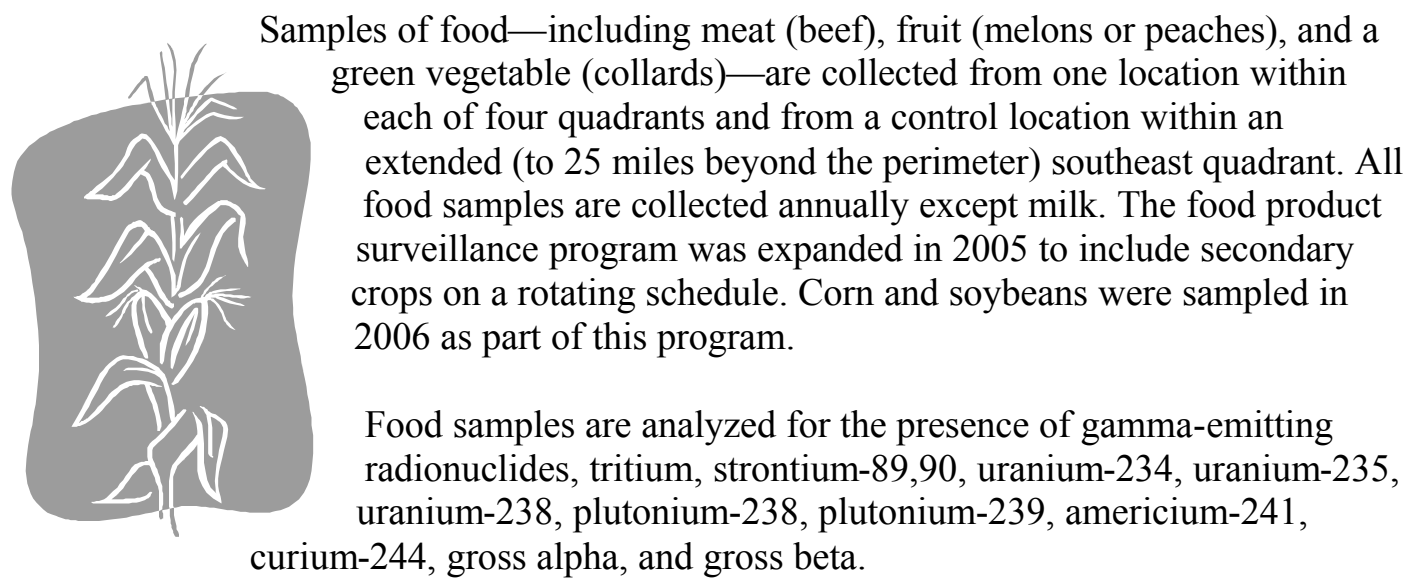




\section{Surveillance Results Summary}

The only gamma-emitting radionuclide detected in food products in 2006 was cesium-137, which was found in collards, corn, and soybeans at one location. Strontium-89,90 was detected in collards at all locations, in soybeans at three locations, and in corn at one location. Tritium was detected in collards at one location. Uranium-234 and uranium-238 were detected in soybeans and corn at one location and in beef at all locations. Americium241 was detected in corn at all locations, in soybeans at one location, and in the CY2005 pecans at the 25-mile-location (results not available for inclusion in the 2005 environmental report). Gross alpha/beta analyses were conducted on all food samples except milk. Gross beta was detected in all food products. Not enough moisture was obtainable from the soybeans to run tritium analyses at any location. The 2006 results appeared to be randomly distributed among the monitoring locations, and no underlying spatial distribution was observed.

Tritium in food products is attributed primarily to releases from SRS; however, tritium was detected in only one food sample. This is similar to results of previous years.

\section{Aquatic Food Products}

\section{Description of Surveillance Program}

The aquatic food product surveillance program includes fish (freshwater and saltwater) and shellfish. To determine the potential dose and risk to the public from consumption, both types are sampled.

Nine surveillance points for the collection of freshwater fish are located on the Savannah River - from above SRS at Augusta, Georgia, to the coast at Savannah, Georgia. In 2006, analyses for technetium-99; iodine-129; and the actinide series (uranium234, 235, and 238, plutonium 238 and 239, americium-241, and curium-244) were added to all samples.

\section{Surveillance Results Summary}

Cesium-137, iodine-129, and technetium-99 were the only manmade gamma-emitting radionuclides found in Savannah River edible fish composites. Strontium-89,90 and tritium were detected at most of the freshwater river locations. Plutonium-238 was found slightly above the MDC in composites from eight freshwater locations. Strontium-89,90, uranium234, uranium-235, uranium-238, and plutonium-238 were detected in both saltwater fish and shellfish. Cesium-137 and strontium-89/90 concentrations were similar to those of previous years.

\section{Deer and Hogs}

\section{Description of Surveillance Program}

Annual hunts, open to members of the general public, are conducted at SRS to control the site's deer and feral hog populations and to reduce animal-vehicle accidents. Before any animal is released to a hunter, EPM personnel use portable sodium iodide detectors to perform field analyses for cesium-137. Media samples (muscle and/or bone) are collected 
periodically for laboratory analysis based on a set frequency, on cesium-137 levels, and/or on exposure limit considerations.

In 2006, SRS established an administrative dose limit of 30 mrem for the consumption of game animals. This limit ensures that no single pathway contributes more than 30 percent to the all-pathway dose limit of 100 mrem, and is consistent with DOE guidance.

\section{Surveillance Results Summary}

A total of 324 deer and 92 feral hogs were taken during the 2006 site hunts. As observed during previous hunts, cesium-137 was the only manmade gamma-emitting radionuclide detected during laboratory analysis. Generally, the cesium-137 concentrations measured by the field and lab methods were comparable. Field measurements from all animals ranged from $1 \mathrm{pCi} / \mathrm{g}$ to $19 \mathrm{pCi} / \mathrm{g}$, while lab measurements ranged from $1 \mathrm{pCi} / \mathrm{g}$

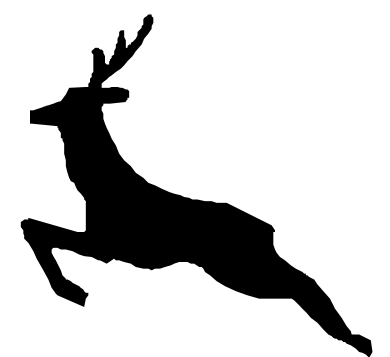
to $17.2 \mathrm{pCi} / \mathrm{g}$. The average field cesium- 137 concentration was $2.65 \mathrm{pCi} / \mathrm{g}$ in deer (with a maximum of $9 \mathrm{pCi} / \mathrm{g}$ ) and $3.19 \mathrm{pCi} / \mathrm{g}$ in hogs (with a maximum of $19 \mathrm{pCi} / \mathrm{g}$ ).

Strontium levels are determined in some of the animals analyzed for cesium-137. Typically, muscle and bone samples are collected for analysis from the same animals checked for cesium-137, and the samples are analyzed for strontium-89,90. As in previous years, strontium-89,90 was not quantified in muscle samples in 2006. Lab measurements of strontium-89,90 in bone ranged from a high of $5.62 \mathrm{pCi} / \mathrm{g}$ to a low of $0.87 \mathrm{pCi} / \mathrm{g}$ in deer and from a high of $3.54 \mathrm{pCi} / \mathrm{g}$ to a low of $1.32 \mathrm{pCi} / \mathrm{g}$ in hogs. These results are similar to those of previous years.

\section{Turkeys/Beavers}

\section{Description of Surveillance Programs}

Prior to 2003, wild turkeys were trapped on site by the South Carolina Department of Natural Resources and used to repopulate game areas in South Carolina and other states. Since that time, the program has remained inactive because of reduced needs.

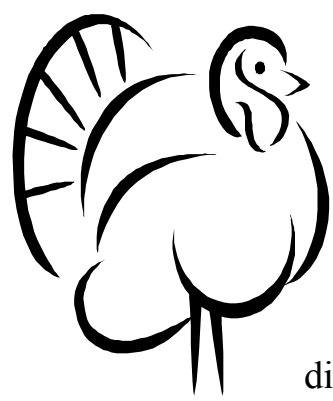

The U.S. Department of Agriculture Forest Service-Savannah River harvests beavers in selected areas within the SRS perimeter to reduce the population and thereby minimize dam-building activities that can result in flood damage to timber stands, to primary and secondary roads, and to railroad beds. This activity resumed during 2006, and the 18 beavers harvested were monitored by EPM to ensure safe and appropriate disposal. None of the harvested animals were near the site's radiological limit for disposal in the Solid Waste Disposal Facility.

During April 2006, a special hunt for the mobility impaired was held that resulted in the harvest of 23 turkeys. The average cesium-137 concentration measured in the field was 1 $\mathrm{pCi} / \mathrm{g}$. 


\section{Soil}

\section{Description of Surveillance Program}

The SRS soil monitoring program provides

- data for long-term trending of radioactivity deposited from the atmosphere (both wet and dry deposition)

- information on the concentrations of radioactive materials in the environment

The concentrations of radionuclides in soil vary greatly among locations because of differences in rainfall patterns and in the mechanics of retention and transport in different types of soils. Because of this program's design, a direct comparison of data from year to year is not appropriate. However, these results may be evaluated over a period of years to determine long-term trends.

\section{Surveillance Results Summary}

In 2006, radionuclides were detected in soil samples from 19 locations, as follows:

- cesium-137 at 17 locations (three onsite, all 10 perimeter, and four offsite)

- uranium-234 at all 19 locations

- uranium-235 at all locations except for one perimeter location

- uranium-238 at all locations except for one perimeter location

- plutonium-238 at 13 locations (three onsite, eight perimeter, and two offsite)

- plutonium-239 at 16 locations (four onsite, nine perimeter, and three offsite)

- americium-241 at 15 locations (three onsite, nine perimeter, and three offsite)

- curium-244 at three locations (one onsite and two offsite)

These results are similar to those of previous years.

\section{Settleable Solids}

\section{Description of Surveillance Program}

Settleable-solids monitoring in effluent water is required to ensure-in conjunction with routine sediment monitoring - that a long-term buildup of radioactive materials does not occur in stream systems.

DOE limits on radioactivity levels in settleable solids are $5 \mathrm{pCi} / \mathrm{g}$ above background for alpha-emitting radionuclides and $50 \mathrm{pCi} / \mathrm{g}$ above background for beta/gamma-emitting radionuclides.

Low total suspended solids (TSS) levels result in a small amount of settleable solids, so an accurate measurement of radioactivity levels in settleable solids is impossible. Based on this, an interpretation of the radioactivity-levels-in-settleable-solids requirement was provided to Westinghouse Savannah River Company (WSRC) by DOE in 1995. The 
interpretation indicated that TSS levels below 40 parts per million (ppm) were considered to be in de-facto compliance with the DOE limits.

To determine compliance with these limits, EPM uses TSS results - gathered as part of the routine National Pollutant Discharge Elimination System (NPDES) monitoring programfrom outfalls co-located at or near radiological effluent points. If an outfall shows that TSS levels regularly are greater than $30 \mathrm{ppm}$, a radioactivity-levels-in-settleable-solids program and an increase in sediment monitoring will be implemented.

\section{Surveillance Results Summary}

In 2006, two TSS samples exceeded $30 \mathrm{ppm}$. One sample from Outfall D-1D had a result of $40 \mathrm{ppm}$ because of a facility wash-down, while a sample from Outfall D-06 had a result of $38 \mathrm{ppm}$ because of construction activities. Overall, the 2006 NPDES TSS results indicate that SRS remains in compliance with the DOE radioactivity-levels-in-settleablesolids requirement.

\section{Sediment}

\section{Description of Surveillance Program}

Sediment sample analysis measures the movement, deposition, and accumulation of longlived radionuclides in stream beds and in the Savannah River bed. Significant year-to-year differences may be evident because of the continuous deposition and remobilization occurring in the stream and river beds - or because of slight variation in sampling locations - but the data obtained can be used to observe long-term environmental trends.

Sediment samples were collected at eight Savannah River and 13 site stream locations in 2006.

\section{Surveillance Results Summary}

Cesium-137 and cobalt-60 were the only manmade gamma-emitting radionuclides observed in river and stream sediments. The highest cesium- 137 concentration in streams, 4.97E $+02 \mathrm{pCi} / \mathrm{g}$, was detected in sediment from R-Canal; the lowest levels were below detection at several locations. The highest level found on the river, $4.86 \mathrm{E}-01 \mathrm{pCi} / \mathrm{g}$, was at River Mile 129; the lowest levels were below detection at several locations. Generally, cesium-137 concentrations were higher in stream sediments than in river sediments. This is to be expected because the streams receive radionuclide-containing liquid effluents from the site. Most radionuclides settle out and deposit on the stream beds or at the streams' entrances to the swamp areas along the river.

Cobalt-60 was detected in stream sediment at a concentration of $4.41 \mathrm{E}-01 \mathrm{pCi} / \mathrm{g}$ at the RCanal location - the only location where cobalt-60 was detected.

Strontium-89,90 was above the MDC in sediment at six stream locations. The maximum detected value was $3.71 \mathrm{E}-01 \mathrm{pCi} / \mathrm{g}$, at the Four Mile Creek at the Road A-7 location. Plutonium-238 was detected in sediment during 2006 at all stream locations and at four river locations. The results ranged from a maximum of $1.39 \mathrm{E}-01 \mathrm{pCi} / \mathrm{g}$ at $\mathrm{FM}-\mathrm{A} 7$ to below detection at several locations. Plutonium-239 was detected in sediment at most stream and 
four river locations. The maximum value was $1.82 \mathrm{E}-01 \mathrm{pCi} / \mathrm{g}-$ also at FM-A7. Uranium234,235 , and 238 were detected at most locations.

The distribution and concentration of radionuclides in river sediment during 2006 were similar to those of previous years.

Concentrations of all isotopes generally were higher in streams than in the river. As indicated in the earlier discussion of cesium-137, this is to be expected. Differences observed when these data are compared to those of previous years probably are attributable to the effects of resuspension and deposition, which occur constantly in sediment media.

\section{Grassy Vegetation \\ Description of Surveillance Program}

The radiological program for grassy vegetation is designed to collect and analyze samples from onsite and offsite locations to determine radionuclide concentrations. Vegetation samples are obtained to complement the soil and sediment samples in order to determine the environmental accumulation of radionuclides and to help confirm the dose models used by SRS. Bermuda grass is preferred because of its importance as a pasture grass for dairy herds.

Vegetation samples are obtained from

- locations containing soil radionuclide concentrations that are expected to be higher than normal background levels

- locations receiving water that may have been contaminated

- all air sampling locations

\section{Surveillance Results Summary}

Radionuclides in the grassy vegetation samples collected in 2006 were detected as follows:

- tritium at two perimeter and one onsite location

- cesium-137 at eight perimeter locations

- $\quad$ strontium-89,90 at all 15 locations sampled

- uranium-234 at 11 locations (all the vegetation sampling sites except three perimeter locations and one offsite location)

- uranium-238 at 11 locations (all the vegetation sampling sites except three perimeter locations and one 25-mile location)

- plutonium-238 at one perimeter, one 25-mile, and at the 100-mile location

- amercium-241 at six locations (four perimeter locations, one 25-mile location, and the Savannah location)

These results are similar to those of previous years. 


\section{Savannah River Swamp Surveys}

\section{Introduction}

The Creek Plantation, a privately owned land area located along the Savannah River, borders part of the southern boundary of SRS. In the 1960s, an area of the Savannah River Swamp on Creek Plantation - specifically, the area between Steel Creek Landing and Little Hell Landing - was contaminated by SRS operations. During high river levels, water from Steel Creek flowed along the lowlands comprising the swamp, resulting in the deposition of radioactive material. SRS studies estimated that a total of approximately $25 \mathrm{Ci}$ of cesium-137 and $1 \mathrm{Ci}$ of cobalt- 60 were deposited in the swamp.

Comprehensive and cursory surveys of the swamp have been conducted periodically since 1974. These surveys measure radioactivity levels to determine changes in the amount and/or distribution of radioactivity in the swamp.

A series of 10 sampling trails - ranging from 240 to 3,200 feet in length — was established through the swamp. Fifty-two monitoring locations were designated on the trails to allow for continued monitoring at a consistent set of locations.

The 2005 survey was designated as a comprehensive survey (requiring extensive media sampling and analysis - as well as exposure rate measurements). Because of high water levels and the absence of suitable vegetation during the 2005, the comprehensive survey was rescheduled for 2006 .

\section{Analytical Results Summary}

Because of high water levels and access difficulties, the 2006 survey could not be completed as planned. The full comprehensive survey now is scheduled to be conducted in 2007.

\section{Nonradiological Surveillance}

\section{Air}

SRS does not conduct onsite surveillance for nonradiological ambient air quality. However, to ensure compliance with SCDHEC air quality regulations and standards, SRNL most recently conducted air dispersion modeling for all site sources of criteria pollutants and toxic air pollutants in 2001. This modeling indicated that all SRS sources were in compliance with air quality regulations and standards. Since that time, additional modeling conducted for new sources of criteria pollutants and toxic air pollutants has demonstrated continued compliance by the site with current applicable regulations and standards. The states of South Carolina and Georgia continue to monitor ambient air quality near the site as part of a network associated with the federal Clean Air Act.

\section{Surface Water}

SRS streams and the Savannah River are classified by SCDHEC as "Freshwaters," which are defined as surface water suitable for 
- primary and secondary contact recreation and as a drinking water source after conventional treatment in accordance with SCDHEC requirements

- fishing and survival and propagation of a balanced indigenous aquatic community of fauna and flora

- industrial and agricultural uses

Appendix A, "Applicable Guidelines, Standards, and Regulations," provides some of the specific guidelines used in water quality surveillance, but because some of these guidelines are not quantifiable, they are not tracked.

\section{Surveillance Results Summary}

At every site, most water quality parameters and metals were detected in at least one sample. Only three samples had detectable pesticides/herbicides in 2006. These results continue to indicate that SRS discharges are not significantly affecting the water quality of the onsite streams or the river.

\section{Drinking Water}

Most of the drinking water at SRS is supplied by three systems that have treatment plants in A-Area, D-Area, and K-Area. The site also has 14 small drinking water facilities, each of which serves populations of fewer than 25 persons.

\section{Surveillance Results Summary}

All samples collected from SRS drinking water systems during 2006 were in compliance with SCDHEC and EPA water quality standards. Additional information is provided in the Safe Drinking Water Act section of chapter 3, "Environmental Compliance."

\section{Sediment}

The nonradiological sediment surveillance program provides a method to determine the deposition, movement, and accumulation of nonradiological contaminants in stream systems.

\section{Surveillance Results Summary}

In 2006, as in the previous 5 years, no pesticides or herbicides were found to be above the quantitation limits in sediment samples. Metals analyses results for 2006 also were comparable to those of the previous 5 years.

\section{Fish}

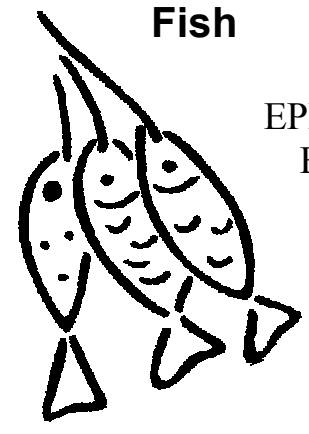

EPM personnel analyze the flesh of fish caught from the Savannah and Edisto Rivers to determine concentrations of mercury in the fish. The fish analyzed represent the most common edible species of fish in the CSRA (freshwater) and at the mouth of the Savannah River (saltwater). 


\section{Surveillance Results Summary}

In 2006, mercury analyses were performed on 159 fish from the Savannah River and 10 from the Edisto River at West Bank Landing. Concentrations of mercury generally were slightly lower than those observed in 2005, but similar to those of previous years. The highest concentrations were found in the Savannah River - in bass at Stokes Bluff Landing $(2.14 \mu \mathrm{g} / \mathrm{g})$, in catfish at Stokes Bluff Landing $(9.76 \mu \mathrm{g} / \mathrm{g})$, and in bream at Highway 17-A $(1.00 \mu \mathrm{g} / \mathrm{g})$.

\section{River Water Quality Surveys}

\section{Description of Surveys}

ANS personnel conducted biological and water quality surveys of the Savannah River from 1951 through 2003, when EPM assumed this responsibility. The surveys were designed to assess potential effects of SRS contaminants and warm-water discharges on the general health of the river and its tributaries. This is accomplished by looking for

- patterns of biological disturbance that are geographically associated with the site

- patterns of change over seasons or years that indicate improving or deteriorating conditions

EPM conducted macroinvertebrate and diatom sampling during the spring and fall of 2006. The diatom slides were sent to ANS for archiving and processing of the 2006 spring collection. No adverse biological impacts were identified in the Savannah River diatom communities.

The number of macroinvertebrates collected from river traps during 2005 was similar to that documented in previous surveys: No adverse biological impacts were observed in the macroinvertebrate communities. Collections from 2006 will be sorted and archived during 2007. 



\title{
Potential Radiation Doses
}

\author{
Timothy Jannik, Patricia Lee, and Eduardo Farfan \\ Savannah River National Laboratory
}

$\mathrm{T}$

HIS chapter presents the potential doses to offsite individuals and the surrounding population from the 2006 Savannah River Site (SRS) atmospheric and liquid radioactive releases. Also documented are potential doses from special-case exposure scenarios - such as the consumption of deer meat, fish, and goat milk.

Unless otherwise noted, the generic term "dose" used in this report includes both the committed effective dose equivalent ( 50 -year committed dose) from internal deposition of radionuclides and the effective dose equivalent attributable to sources external to the body. Use of the effective dose equivalent allows doses from different types of radiation and to different parts of the body to be expressed on the same basis.

Descriptions of the effluent monitoring and environmental surveillance programs discussed in this chapter can be found in chapter 4, "Effluent Monitoring," and chapter 5, "Environmental Surveillance." A complete description of how potential doses are calculated can be found in section 1108 of the Savannah River Site Environmental Monitoring Section Plans and Procedures, WSRC-3Q1-2, Volume 1 [SRS EM Program, 2001]. All potential dose calculation results are presented in data tables on the CD accompanying this report.

\section{Dose to the Hypothetical Maximally Exposed Individual}

When calculating radiation doses to the public, SRS uses the concept of the maximally exposed individual; however, because of the conservative lifestyle assumptions used in the dose models. no such person is known to exist. The parameters used for the dose calculations are as follows:

For airborne releases: Someone who lives at the SRS boundary 365 days per year and consumes milk, meat, and vegetables produced at that location

For liquid releases: Someone who lives downriver of SRS (near River Mile 118.8) 365 days per year, drinks 2 liters of untreated water per day from the Savannah River, consumes $19 \mathrm{~kg}$ (42 pounds) per year of Savannah River fish, and spends the majority of time on or near the river

To demonstrate compliance with the DOE Order 5400.5 all-pathway dose standard of 100 mrem per year, SRS conservatively combines the airborne pathway and liquid pathway dose estimates, even though the two doses are calculated for hypothetical individuals residing at different geographic locations. 


\section{Calculating Dose}

Potential offsite doses from SRS effluent releases of radioactive materials (atmospheric and liquid) are calculated for the following scenarios:

- hypothetical maximally exposed individual living at the SRS boundary (see definition below)

- population living within an 80-km (50-mile) radius of SRS

Because the U.S. Department of Energy (DOE) has adopted dose factors only for adults, SRS calculates maximally exposed individual and collective doses as if the entire $80-\mathrm{km}$ population consisted of adults [DOE, 1988]. For the radioisotopes that contribute the most to SRS's estimated maximum individual doses (i.e., tritium and cesium-137), the dose to infants could be approximately two to three times more than to adults. The dose to older children becomes progressively closer to the adult dose.

SRS also uses adult consumption rates for food and drinking water and adult usage parameters to estimate intakes of radionuclides. These intake values and parameters were developed specifically for SRS based on a regional survey [Hamby, 1991].

For dose calculations, unspecified alpha releases were conservatively treated as plutonium239 , and unspecified beta releases were treated as strontium-90. These radionuclides have the highest dose factors of the alpha- and beta-emitters, respectively, that are commonly found in SRS waste streams.

\section{Dose Calculation Methods}

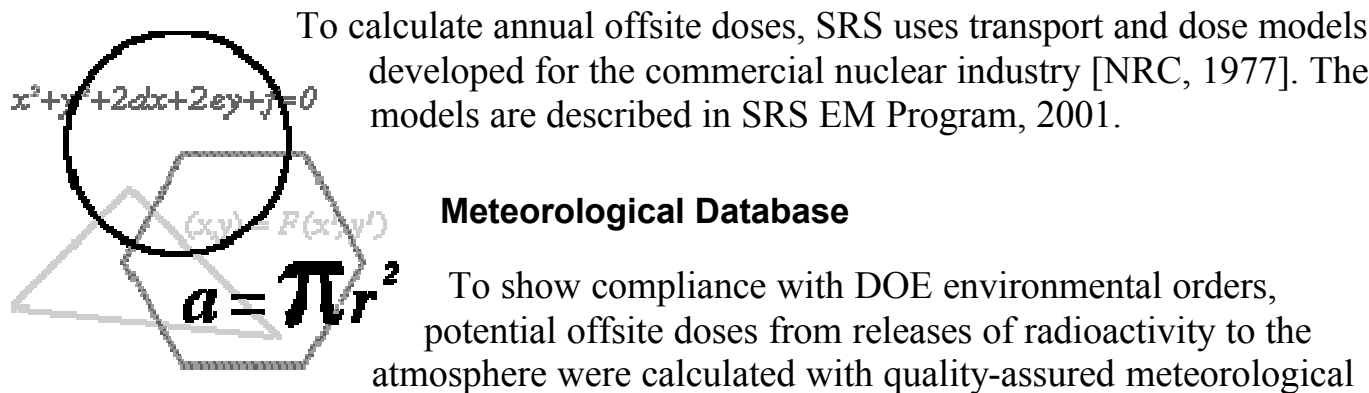

data for A-Area, K-Area (used for releases from C-Area, K-Area, and L-Area), and H-Area (used for releases from all other areas). The meteorological databases used were for the years 1997-2001, reflecting the most recent 5-year compilation period.

To show compliance with U.S. Environmental Protection Agency (EPA) regulations, only the H-Area database was used in the calculations because the EPA-required dosimetry code (CAP88) is limited to a single release location.

\section{Population Database and Distribution}

Collective (population) doses from atmospheric releases are calculated for the population within an $80-\mathrm{km}$ radius of SRS. Within this radius, the total population is 713,500 , based on 2000 census data.

Some of the collective doses resulting from SRS liquid releases are calculated for the populations served by the City of Savannah Industrial and Domestic Water Supply Plant 
(Savannah I\&D), near Port Wentworth, Georgia, and by the Beaufort-Jasper Water and Sewer Authority's (BJWSA) Chelsea and Purrysburg Water Treatment Plants, near Beaufort, South Carolina. According to the treatment plant operators, the population served by the Savannah I\&D facility during 2006 was 26,300 persons, while the population served by the BJWSA Chelsea facility was 77,000 persons and by the BJWSA Purrysburg facility, 58,000 persons.

\section{River Flow Rate Data}

Savannah River flow rates are recorded at a gauging station near River Mile 118.8 (U.S. Highway 301 bridge), and are based on the measured water elevation. However, these data are not used directly in dose calculations because daily river flow rates fluctuate widely (i.e., short-term dilution varies from day to day). Used instead are "effective" flow rates, which are based on the annual average tritium concentrations measured at River Mile 118.8 and at the three downriver water treatment plants. The use of effective river flow rates in the dose calculations is more conservative than the use of measured flow rates because it accounts for less dilution of other radionuclides.

For 2006, the River Mile 118.8 calculated (effective) flow rate of 5,788 cubic feet per second (cfs) was used. For comparison, the 2006 measured annual average flow rate was 9,392 cfs. The 2006 effective flow rate was 37 percent less than the 2005 effective flow rate of $9,188 \mathrm{cfs}$.

The 2006 effective flow rate was 7,764 cfs for the Savannah I\&D facility, 8,413 cfs for the BJWSA Chelsea facility, and 7,265 cfs for the BJWSA Purrysburg facility.

\section{Dose Calculation Results}

\section{Liquid Pathway}

\section{Liquid Release Source Terms}

The 2006 radioactive liquid release quantities used as the source term in SRS dose calculations are discussed in chapter 4 and shown by radionuclide in table 6-1.

Tritium accounts for more than 99 percent of the total amount of radioactivity released from the site to the Savannah River. In 2006, a total of 1,640 curies of tritium were released from SRS to the river. In the recent past, the total amount of tritium used in SRS dose calculation was based on the measured tritium concentration at River Mile 118.8. However, the total from this location includes the tritium releases from Georgia Power Company's Vogtle Electric Generating Plant (VEGP). Beginning in 2006, maximallyexposed-individual doses will be calculated and documented in this report using SRS-only releases. Data from continuously monitored liquid effluent discharge points are used in conjunction with site seepage basin and Solid Waste Disposal Facility migration release measurements to quantify the total tritium released from SRS. A separate dose calculation will be performed that includes the total amount of tritium (SRS plus VEGP) measured at River Mile 118.8, which in 2006 was 3,330 curies. 


\section{Radionuclide Concentrations in Savannah River Water, Drinking Water, and Fish}

The concentrations of tritium in Savannah River water and cesium-137 in Savannah River fish are measured at several locations along the river for use in dose determinations and model comparisons. The amounts of all other radionuclides released from SRS are so small that they usually cannot be detected in the Savannah River using conventional analytical techniques.

Radionuclide Concentrations in River Water and Treated Drinking Water The measured concentrations of tritium in the Savannah River near River Mile 118.8 and at the Savannah I\&D and BJWSA water treatment facilities are shown in table 6-1, as are the calculated concentrations for the other released radionuclides. These downriver tritium concentrations include the tritium releases from SRS and the neighboring VEGP.

Because of reduced river flow in 2006 compared to 2005, the 12-month average tritium concentration measured in Savannah River water near River Mile $118.8(0.645 \mathrm{pCi} / \mathrm{mL})$ was 18 percent more than the 2005 concentration of $0.546 \mathrm{pCi} / \mathrm{mL}$. The concentrations at the BJSWA Chelsea $(0.443 \mathrm{pCi} / \mathrm{mL})$ and Purrysburg $(0.513 \mathrm{pCi} / \mathrm{mL})$ facilities, and at the Savannah I\&D $(0.480 \mathrm{pCi} / \mathrm{mL})$ water treatment plant, remained below the EPA maximum contaminant level (MCL) of $20 \mathrm{pCi} / \mathrm{mL}$.

Table 6-1

2006 Radioactive Liquid Release Source Term and 12-Month Average Downriver Radionuclide Concentrations Compared to EPA's Drinking Water Maximum Contaminant Levels (MCLs)

\begin{tabular}{|c|c|c|c|c|c|c|}
\hline \multirow[b]{2}{*}{ Nuclide } & \multirow[b]{2}{*}{$\begin{array}{l}\text { Curies } \\
\text { Released }\end{array}$} & \multicolumn{5}{|c|}{ 12-Month Average Concentration (pCi/mL) } \\
\hline & & $\begin{array}{l}\text { Below } \\
\text { SRS }^{(a)}\end{array}$ & $\begin{array}{l}\text { BJWSA } \\
\text { Chelsea }\end{array}$ & $\begin{array}{l}\text { BJWSA } \\
\text { Purrysburg }\end{array}$ & $\begin{array}{l}\text { Savannah } \\
\text { I\&D }\end{array}$ & EPA MCL \\
\hline $\mathrm{H}-3^{\mathrm{b}}$ & $3.33 E+03$ & $6.45 \mathrm{E}-01$ & 4.43E-01 & 5.13E-01 & 4.80E-01 & $2.00 E+01$ \\
\hline Sr-90 & $3.51 \mathrm{E}-02$ & $6.80 \mathrm{E}-06$ & 4.67E-06 & 5.41E-06 & 5.06E-06 & 8.00E-03 \\
\hline Tc-99 & $6.38 \mathrm{E}-03$ & $1.24 \mathrm{E}-06$ & 8.49E-07 & 9.83E-07 & $9.20 \mathrm{E}-07$ & $9.00 \mathrm{E}-01$ \\
\hline I-129 & 8.31E-03 & $1.61 \mathrm{E}-06$ & 1.11E-06 & $1.28 \mathrm{E}-06$ & $1.20 \mathrm{E}-06$ & $1.00 \mathrm{E}-03$ \\
\hline Cs-137 & 8.87E-02 & $1.72 \mathrm{E}-05$ & 1.18E-05 & 1.37E-05 & $1.28 \mathrm{E}-05$ & $2.00 \mathrm{E}-01$ \\
\hline U-234 & $6.50 \mathrm{E}-04$ & 1.26E-07 & 8.65E-08 & 1.00E-07 & 9.37E-08 & $1.87 \mathrm{E}+02$ \\
\hline U-235 & $2.50 \mathrm{E}-05$ & 4.84E-09 & 3.33E-09 & 3.85E-09 & 3.61E-09 & 6.48E-02 \\
\hline U-238 & 7.18E-04 & 1.39E-07 & 9.56E-08 & 1.11E-07 & 1.04E-07 & 1.01E-02 \\
\hline Pu-238 & 3.65E-04 & 7.07E-08 & 4.86E-08 & 5.63E-08 & 5.26E-08 & $1.50 \mathrm{E}-02$ \\
\hline Pu-239 & $4.86 \mathrm{E}-05$ & 9.42E-09 & 6.47E-09 & 7.49E-09 & 7.01E-09 & $1.50 \mathrm{E}-02$ \\
\hline Am-241 & 7.62E-05 & 1.48E-08 & 1.01E-08 & 1.17E-08 & 1.10E-08 & 1.50E-02 \\
\hline Cm-244 & 3.59E-05 & 6.96E-09 & 4.78E-09 & 5.53E-09 & 5.18E-09 & $1.50 \mathrm{E}-02$ \\
\hline Alpha & 3.14E-02 & 6.08E-06 & 4.18E-06 & 4.84E-06 & 4.53E-06 & $1.50 \mathrm{E}-02$ \\
\hline Beta & 3.83E-02 & 7.42E-06 & 5.10E-06 & 5.90E-06 & 5.52E-06 & 8.00E-03 \\
\hline
\end{tabular}


The MCL for each radionuclide released from SRS during 2006 is provided in table 6-1. The table indicates that all individual radionuclide concentrations at the three downriver community drinking water systems, as well as at River Mile 118.8, were below the MCLs.

Because more than one radionuclide is released from SRS, the sum of the fractions of the observed concentration of each radionuclide to its corresponding MCL must not exceed 1.0 .

The sum of the fractions was 0.0248 at the BJSWA Chelsea facility, 0.0288 at the BJSWA Purrysburg facility, and 0.0269 at the Savannah I\&D facility. These are below the 1.0 sumof-the-fractions requirement.

For 2006, the sum of the fractions at the River Mile 118.8 location was 0.0362 . This is provided only for comparison because River Mile 118.8 is not a community water system location.

Radionuclide Concentrations in River Fish At SRS, an important dose pathway for the maximally exposed individual is from the consumption of fish.

Fish exhibit a high degree of bioaccumulation for certain elements. For the element cesium (including radioactive isotopes of cesium), the bioaccumulation factor for Savannah River fish is approximately 3,000. That is, the concentration of cesium found in fish flesh is about 3,000 times the concentration of cesium found in the water in which the fish live [Carlton et al, 1994].

Because of this high bioaccumulation factor, cesium-137 is more easily detected in fish flesh than in river water. Therefore, the fish pathway dose from cesium-137 normally is based directly on the radioanalysis of the fish collected near Savannah River Mile 118.8, which is the assumed location of the hypothetical maximally exposed individual. However, in 2006, the calculated concentration of cesium-137 in fish, which is based on measured effluent releases, again was determined to be more than the actual measured concentrations in fish.

To be conservative, the higher calculated cesium-137 concentrations were used in the 2006 dose determinations.

\section{Dose to the Maximally Exposed Individual}

As shown in table 6-2, the highest potential dose to the maximally exposed individual from liquid releases in 2006 was estimated at 0.09 mrem $(0.0009 \mathrm{mSv})$. This dose is 0.09 percent of the DOE Order 5400.5 ("Radiation Protection of the Public and the Environment”) 100-mrem all-pathway dose standard for annual exposure. Even though the VEGP tritium releases were not included in the source term, the 2006 SRS-only dose is 12 percent more than the reported 2005 dose of $0.08 \mathrm{mrem}(0.0008 \mathrm{mSv})$. This increase is attributed to (1) the lower river flow rate in 2006 compared to 2005 (which caused less dilution to occur) and (2) an increase in unspecified alpha and beta releases from SRS's Separations Area. 
Table 6-2

Potential Dose to the Maximally Exposed Individual from SRS Liquid Releases in 2006

\begin{tabular}{|c|c|c|c|}
\hline & $\begin{array}{l}\text { Committed Dose } \\
\text { (mrem) }\end{array}$ & $\begin{array}{l}\text { Applicable } \\
\text { standard (mrem) }\end{array}$ & $\begin{array}{l}\text { Percent of } \\
\text { Standard }\end{array}$ \\
\hline \multicolumn{4}{|c|}{ Maximally Exposed Individual } \\
\hline $\begin{array}{l}\text { Near Site Boundary } \\
\text { (all liquid pathways) }\end{array}$ & 0.09 & $100^{a}$ & 0.09 \\
\hline $\begin{array}{l}\text { At BJSWA Chelsea } \\
\text { (public water supply only) }\end{array}$ & 0.03 & $4^{b}$ & 0.75 \\
\hline $\begin{array}{l}\text { At BJSWA Purrysburg } \\
\text { (public water supply only) }\end{array}$ & 0.03 & $4^{b}$ & 0.75 \\
\hline $\begin{array}{l}\text { At Savannah I\&D } \\
\text { (public water supply only) }\end{array}$ & 0.03 & $4^{b}$ & 0.75 \\
\hline
\end{tabular}

Approximately 56 percent of the 2006 dose to the maximally exposed individual resulted from the ingestion of cesium-137, mainly from the consumption of fish. About 24 percent and 17 percent of the dose resulted from the ingestion (mainly via drinking water) of unspecified alpha emitters and tritium, respectively.

Using the 2006 total tritium source term (which includes SRS and VEGP releases measured at River Mile 118.8) of 3,330 curies, the maximally-exposed individual-dose was calculated to be $0.1 \mathrm{mrem}(0.001 \mathrm{mSv})$.

This dose is 25 percent more than the equivalent reported 2005 dose of 0.08 mrem $(0.0008$ $\mathrm{mSv}$ ).

Drinking Water Pathway Persons downriver of SRS may receive a radiation dose by consuming drinking water that contains radioactivity as a result of liquid releases from the site. In 2006, unspecified alpha-emitters in downriver drinking water represented the majority of the dose (about 49 percent) received by persons at the three downriver water treatment plants. Tritium accounted for about 44 percent.

Based on SRS-only releases, the maximum potential drinking water dose during 2006 was determined to be $0.03 \mathrm{mrem}(0.0003 \mathrm{mSv})$ - the same as the 2005 dose. As shown in table $6-2$, the maximum dose of $0.03 \mathrm{mrem}(0.0003 \mathrm{mSv})$ is 0.75 percent of the DOE standard of 4 mrem per year for public water supplies.

Using the SRS-plus-VEGP total tritium source term of 3,330 curies, the maximum drinking water dose was calculated to be $0.04 \mathrm{mrem}(0.0004 \mathrm{mSv})$ in 2006.

\section{Collective (Population) Dose}

The collective drinking water consumption dose is calculated for the discrete population groups served by the BJWSA and Savannah I\&D water treatment plants. The collective dose from other pathways is calculated for a diffuse population that makes use of the Savannah River; however, this population cannot be described as being in a specific geographical location. 
In 2006, the collective dose from SRS liquid releases was estimated at 2.9 person-rem ( 0.029 person-Sv). This is 16 percent more than the 2005 collective dose of 2.5 person-rem (0.025 person-Sv).

Using the SRS-plus-VEGP total tritium source term of 3,330 curies, the collective dose was calculated to be 3.9 person-rem (0.039 person-Sv) in 2006.

\section{Potential Dose from Agricultural Irrigation}

Based on surveys of county agricultural extension agencies, there are no known large-scale uses of river water downstream of SRS for agricultural irrigation purposes. However, the potential for irrigation does exist, so potential doses from this pathway are calculated for information purposes only but are not included in calculations of the official maximally exposed individual or collective doses.

As in previous years, collective doses from agricultural irrigation were calculated for 1,000 acres of land devoted to each of four major food types - vegetation, leafy vegetation, milk, and meat. It is assumed that all the food produced on the 1,000-acre parcels is consumed by the $80-\mathrm{km}$ population of 713,500 .

For 2006, a potential offsite dose of $0.079 \mathrm{mrem}(0.00079 \mathrm{mSv})$ to the maximally exposed individual and a collective dose of 5.1 person-rem $(0.051$ person-Sv) were estimated for this exposure pathway.

\section{Air Pathway}

\section{Atmospheric Source Terms}

The 2006 radioactive atmospheric release quantities used as the source term in SRS dose calculations are discussed in chapter 4 . Estimates of unmonitored diffuse and fugitive sources were included in the atmospheric source term, as required, for demonstrating compliance with NESHAP regulations.

\section{Atmospheric Concentrations}

Calculated radionuclide concentrations are used for dose determinations instead of measured concentrations. This is because most radionuclides released from SRS cannot be measured (using standard methods) in the air samples collected at the site perimeter and offsite locations. However, the concentrations of tritium oxide at the site perimeter locations usually can be measured and are compared with calculated concentrations as a verification of the dose models.

\section{Dose to the Maximally Exposed Individual}

In 2006, the estimated dose from atmospheric releases to the maximally exposed individual was $0.11 \mathrm{mrem}(0.0011 \mathrm{mSv})$, which is 1.1 percent of the DOE Order 5400.5 air pathway standard of 10 mrem per year. Table 6-3 compares the maximally-exposed-individual dose with the DOE standard. The 2006 dose is greater than the 2005 maximally-exposed- 


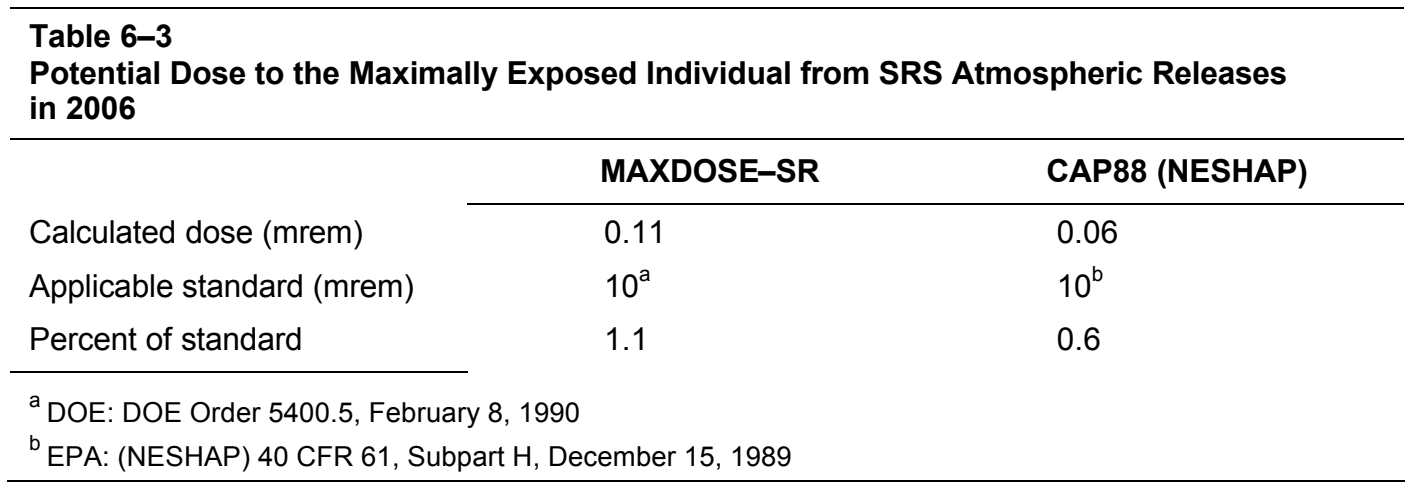

individual dose of $0.05 \mathrm{mrem}(0.0005 \mathrm{mSv})$. This increase in dose is attributed to increases in the estimated diffuse and fugitive releases of unspecified alpha- and beta-emittersprimarily from a specific remediation project, General Separations Area Consolidated Unit (GSACU). Because this project was completed in 2006, its source term will not be a factor in future dose calculations. By definition, diffuse and fugitive releases cannot be measured but are conservatively estimated based on the inventory of residual radionuclides in waste sites being remediated.

Unspecified alpha emitters accounted for about 27 percent of the dose to the maximally exposed individual, and tritium oxide releases accounted for about 21 percent of the dose. No other individual radionuclide accounted for more than 10 percent of the maximallyexposed-individual dose.

The major pathways contributing to the maximally-exposed-individual dose from atmospheric releases were the consumption of vegetation (46 percent), inhalation (42 percent), ground exposure ( 6 percent), and meat and milk consumption ( 6 percent). For 2006, the east-northeast sector of the site was the location of the highest dose to the maximally exposed individual.

Additional calculations of the dose to the maximally exposed individual were performed substituting goat milk for the customary cow milk pathway. The potential dose using the goat milk pathway was estimated at $0.12 \mathrm{mrem}(0.0012 \mathrm{mSv})$.

\section{Collective (Population) Dose}

In 2006, the airborne-pathway collective dose was estimated at 5.0 person-rem (0.05 person-Sv) - less than 0.01 percent of the annual collective dose received from natural sources of radiation (about 214,000 person-rem). Tritium oxide releases accounted for about 32 percent of the collective dose. The 2006 collective dose is 100 percent more than the 2005 collective dose of 2.5 person-rem ( 0.025 person-Sv). Again, the relatively large increase in dose is attributed to large increases in the estimated diffuse and fugitive releases of unspecified alpha- and beta-emitters from the various General Separations Area remediation projects.

\section{NESHAP Compliance}

To demonstrate compliance with NESHAP regulations, maximally exposed individual and collective doses were calculated using the CAP88 computer code [EPA, 2002], and a percentage of dose contribution from each radionuclide was determined. 
The CAP88 code estimates a higher dose for tritium oxide than do the MAXDOSE-SR and POPDOSE-SR codes, which are used to demonstrate compliance with DOE environmental orders [SRS EM Program, 2001]. Most of the differences occur in the tritium dose estimated from food consumption. The major cause of this difference is the CAP88 code's use of 100-percent equilibrium between tritium in air moisture and tritium in food moisture, whereas the MAXDOSE-SR and POPDOSE-SR codes use 50-percent equilibrium values, as recommended by the Nuclear Regulatory Commission [NRC, 1977]. A site-specific study indicated that the 50-percent value is correct for the atmospheric conditions at SRS [Hamby and Bauer, 1994].

Because tritium oxide dominates the doses determined using the CAP88 code, other radionuclides (such as iodine-129) are less important - on a percentage-of-dose basis - for the CAP88 doses than for the MAXDOSE-SR and POPDOSE-SR doses.

For 2006, the maximally-exposed-individual dose was estimated at 0.06 mrem $(0.0006$ $\mathrm{mSv}$ ), which is 0.6 percent of the 10-mrem-per-year EPA standard, as shown in table 6-3. Tritium oxide releases accounted for about 67 percent of this dose.

For NESHAP, the dose from diffuse and fugitive releases is required to be reported separately. For 2006, the maximally-exposed-individual dose from diffuse and fugitive releases was estimated to be $0.032 \mathrm{mrem}(0.00032 \mathrm{mSv})$, which accounts for more than half the total maximally-exposed-individual dose.

The CAP88-determined collective dose was estimated at 7.2 person-rem $(0.072$ personSv). Tritium oxide releases accounted for about 66 percent of this dose.

\section{All-Pathway Dose}

To demonstrate compliance with the DOE Order 5400.5 all-pathway dose standard of 100 mrem $(1.0 \mathrm{mSv})$ per year, SRS conservatively combines the maximally exposed individual airborne pathway and liquid pathway dose estimates, even though the two doses are calculated for hypothetical individuals residing at different geographic locations.

For 2006, the potential maximally exposed individual all-pathway dose was $0.2 \mathrm{mrem}$ $(0.002 \mathrm{mSv})-0.11 \mathrm{mrem}$ from airborne pathways plus 0.09 mrem from liquid pathwaysand is 0.20 percent of the 100 -mrem-per-year DOE dose standard. Although this dose is greater than the 2005 all-pathway dose of $0.13 \mathrm{mrem}(0.0013 \mathrm{mSv})$, the increase is attributed primarily to an increase in diffuse and fugitive releases of unspecified alpha- and beta-emitters generated by the one-time GSACU remediation project discussed earlier.

Figure 6-1 shows a 10-year history of SRS's all-pathway doses (airborne pathway plus liquid pathway doses to the maximally exposed individual).

\section{Sportsman Dose}

DOE Order 5400.5 specifies radiation dose standards for individual members of the public. The dose standard of 100 mrem per year includes doses a person receives from routine DOE operations through all exposure pathways. Nontypical exposure pathways, not included in the standard calculations of the doses to the maximally exposed individual, are considered and quantified separately. This is because they apply to low-probability 


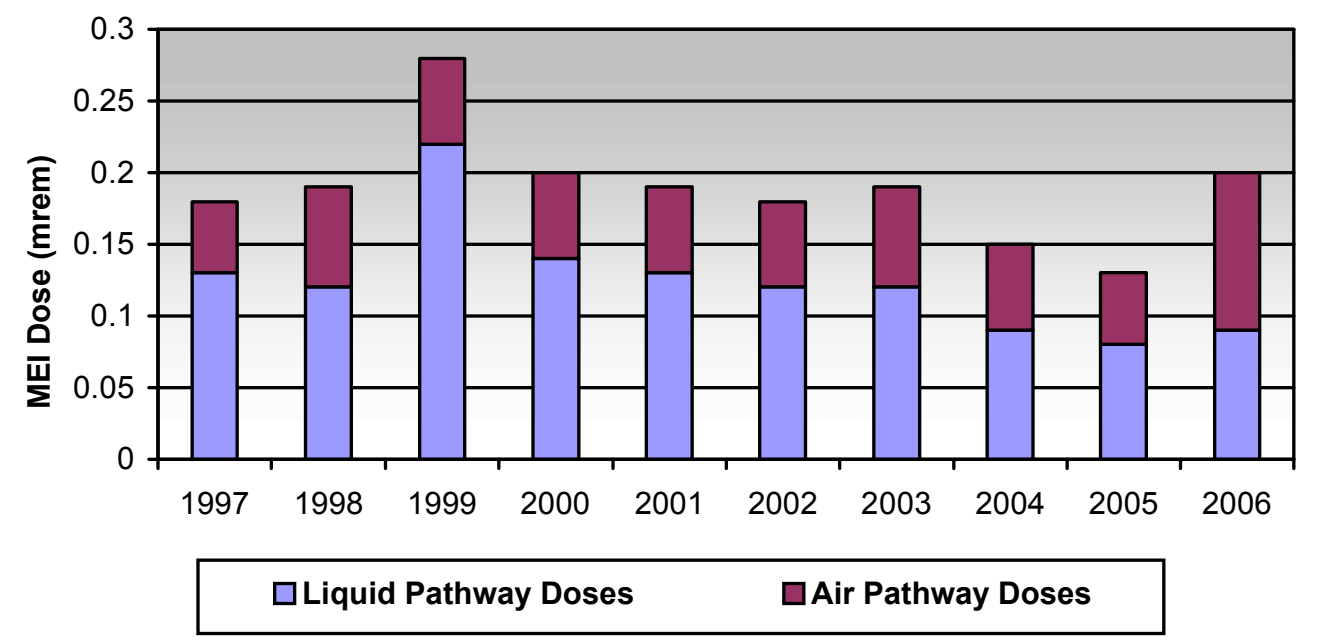

Figure 6-1 Ten-Year History of SRS Maximum Potential All-Pathway Doses

scenarios, such as consumption of fish caught exclusively from the mouths of SRS streams, or to unique scenarios, such as volunteer deer hunters.

In addition to deer, hog, and fish consumption, the following exposure pathways were considered for an offsite hunter and an offsite fisherman - both on Creek Plantation, a privately owned portion of the Savannah River Swamp, which was contaminated by SRS operations in the 1960s (chapter 5):

- External exposure to contaminated soil

- Incidental ingestion of contaminated soil

- Incidental inhalation of resuspended contaminated soil

\section{Onsite Hunter Dose}

Deer and Hog Consumption Pathway The estimated dose from the consumption of harvested deer or hog meat is determined for every onsite hunter.

During 2006, the maximum dose that could have been received by an actual onsite hunter was estimated at $22 \mathrm{mrem}(0.22 \mathrm{mSv})$, or 22 percent of DOE's 100-mrem all-pathway dose standard (table 6-4). This dose was determined for an actual hunter who in fact harvested six animals (five deer and one hog) during the 2006 hunts. The hunter-dose calculation is based on the conservative assumption that this hunter individually consumed the entire edible portion - approximately $108 \mathrm{~kg}$ (239 pounds) — of the animals he harvested from SRS. 


\section{Offsite Hunter Dose}

Deer and Hog Consumption Pathway The deer and hog consumption pathway considered was for hypothetical offsite individuals whose entire intake of meat during the year was either deer or hog meat. It was assumed that these individuals harvested deer or hogs that had resided on SRS, but then moved off site.

Based on these low-probability assumptions and on the measured average concentration of cesium-137 in all deer $(2.65 \mathrm{pCi} / \mathrm{g})$ and hogs $(3.19 \mathrm{pCi} / \mathrm{g})$ harvested from SRS during 2006 , the potential maximum doses from this pathway were estimated at $6.7 \mathrm{mrem}(0.067$ $\mathrm{mSv})$ for the deer hunter and at $8.9 \mathrm{mrem}(0.089 \mathrm{mSv})$ for the hog hunter.

A background cesium-137 concentration of $1 \mathrm{pCi} / \mathrm{g}$ is subtracted from the onsite average concentrations before calculating the doses. The background concentration is based on previous analyses of deer harvested at least $80 \mathrm{~km}$ from SRS (table 33, SRS Environmental Data for 1994, WSRC-TR-95-077).

Table 6-4

2006 Maximum Potential All-Pathway and Sportsman Doses Compared to the DOE All-Pathway Dose Standard

\begin{tabular}{|c|c|c|c|}
\hline & $\begin{array}{l}\text { Committed } \\
\text { Dose (mrem) }\end{array}$ & $\begin{array}{l}\text { Applicable } \\
\text { Standard } \\
(\text { mrem) })^{a}\end{array}$ & $\begin{array}{l}\text { Percent of } \\
\text { Standard }\end{array}$ \\
\hline \multicolumn{4}{|l|}{ Maximally-Exposed-Individual Dose } \\
\hline $\begin{array}{l}\text { All-Pathway } \\
\text { (Liquid Plus Airborne Pathway) }\end{array}$ & 0.20 & 100 & 0.20 \\
\hline \multicolumn{4}{|l|}{ Sportsman Dose } \\
\hline Onsite Hunter & 22 & 100 & 22 \\
\hline Creek Mouth Fisherman ${ }^{\mathrm{b}}$ & 0.24 & 100 & 0.24 \\
\hline \multicolumn{4}{|l|}{ Savannah River Hunter } \\
\hline Offsite Deer Consumption & 6.7 & & \\
\hline Offsite Hog Consumption & 8.9 & & \\
\hline Soil Exposure & 2.9 & & \\
\hline Total Offsite Deer Hunter Dose & 9.6 & 100 & 9.6 \\
\hline \multicolumn{4}{|l|}{ Savannah River Swamp Fisherman } \\
\hline Steel Creek Fish Consumption & 0.24 & & \\
\hline Soil Exposure ${ }^{d}$ & 0.28 & & \\
\hline Total Offsite Fisherman Dose & 0.52 & 100 & 0.52 \\
\hline \multicolumn{4}{|c|}{ a All-pathway dose standard: 100 mrem per year (DOE Order 5400.5) } \\
\hline \multicolumn{4}{|c|}{$\begin{array}{l}\text { b In } 2006 \text {, the maximum fisherman dose was caused by the consumption of bass from the mouth of Steel } \\
\text { Creek. }\end{array}$} \\
\hline \multicolumn{4}{|c|}{$\begin{array}{l}{ }^{\mathrm{c}} \text { Includes the dose from a combination of external exposure to-and incidental ingestion and inhalation of- } \\
\text { the worst-case Savannah River Swamp soil }\end{array}$} \\
\hline \multicolumn{4}{|c|}{$\begin{array}{l}{ }^{d} \text { Includes the dose from a combination of external exposure to-and incidental ingestion and inhalation of- } \\
\text { Savannah River Swamp soil near the mouth of Steel Creek }\end{array}$} \\
\hline
\end{tabular}


Savannah River Swamp Hunter Soil Exposure Pathway The potential dose to a recreational hunter exposed to SRS legacy contamination in Savannah River Swamp soil on the privately owned Creek Plantation in 2006 was estimated using the RESRAD dosimetry [Yu et al., 2001]. It was assumed that this recreational sportsman hunted for 120 hours during the year ( 8 hours per day for 15 days) at the location of maximum radionuclide contamination.

Using the worst-case radionuclide concentrations from the most recent comprehensive survey - conducted in 2005 - the potential dose to a hunter from a combination of (1) external exposure to the contaminated soil, (2) incidental ingestion of the soil, and (3) incidental inhalation of resuspended soil was estimated to be $2.9 \mathrm{mrem}(0.029 \mathrm{mSv})$. As shown in table 6-4, the offsite deer consumption pathway and the Savannah River Swamp hunter soil exposure pathway were conservatively added together to obtain a total offsite hunter dose of $9.6 \mathrm{mrem}(0.096 \mathrm{mSv})$. This potential dose is 9.6 percent of the DOE 100-mrem all-pathway dose standard.

\section{Offsite Fisherman Dose}

Creek Mouth Fish Consumption Pathway For 2006, radioanalyses were conducted of fish taken from the mouths of five SRS streams, and the resulting estimated doses were calculated. As shown in table 6-4, the maximum potential dose from this pathway was estimated at $0.24 \mathrm{mrem}(0.0024 \mathrm{mSv})$ from the consumption of bass collected at the mouth of Steel Creek. This hypothetical dose is based on the low-probability scenario that, during 2006, a fisherman consumed $19 \mathrm{~kg}$ of bass caught exclusively from the mouth of Steel Creek. About 86 percent of this potential dose was from cesium-137.

Savannah River Swamp Fisherman Soil Exposure Pathway The potential dose to a recreational fisherman exposed to SRS legacy contamination in Savannah River Swamp soil on the privately owned Creek Plantation in 2006 was estimated using the RESRAD dosimetry code [Yu et al., 2001]. It was assumed that this recreational sportsman fished on the South Carolina bank of the Savannah River near the mouth of Steel Creek for 250 hours during the year.

During the comprehensive survey of the Savannah River Swamp conducted in 2005, the location on Creek Plantation that was closest to the South Carolina bank of the Savannah River and the mouth of Steel Creek was on trail 1, at a distance of 0 feet from the Savannah River.

Using the radionuclide concentrations measured at this location, the potential dose to a fisherman from a combination of (1) external exposure to the contaminated soil, (2) incidental ingestion of the soil, and (3) incidental inhalation of resuspended soil was estimated to be $0.28 \mathrm{mrem}(0.0028 \mathrm{mSv})$.

As shown in table 6-4, the maximum Steel Creek mouth fish consumption dose $(0.24$ mrem) and the Savannah River Swamp fisherman soil exposure pathway were conservatively added together to obtain a total offsite creek mouth fisherman dose of 0.52 mrem $(0.0052 \mathrm{mSv})$. This potential dose is 0.52 percent of the DOE 100-mrem all-pathway dose standard. 


\section{Potential Risk from Consumption of SRS Creek Mouth Fish}

During 1991 and 1992, in response to a U.S. House of Representatives Appropriations Committee request for a plan to evaluate risk to the public from fish collected from the Savannah River, SRS developed - in conjunction with EPA, the Georgia Department of Natural Resources, and the South Carolina Department of Health and Environmental Control - the Westinghouse Savannah River Company/Environmental Monitoring Section Fish Monitoring Plan, which is summarized in SRS EM Program, 2001. Among the reporting requirements of this plan are (1) assessing radiological risk from the consumption of Savannah River fish and (2) presenting a summary of the results in the annual SRS Environmental Report.

Risk Comparisons For 2006, the maximum potential radiation doses and lifetime risks from the consumption of SRS creek mouth fish for 1-year, 30-year, and 50-year exposure durations are shown in table $6-5$ and are compared to the radiation risks associated with the DOE Order 5400.5 all-pathway dose standard of $100 \mathrm{mrem}(1.0 \mathrm{mSv})$ per year. The potential risks were estimated using the cancer morbidity risk coefficients from Federal Guidance Report No. 13 [EPA, 1999].

For 2006, the maximum recreational fisherman dose was caused by the consumption of bass collected at the mouth of Steel Creek. Figure 6-2 shows a 10-year history of the annual potential radiation doses from consumption of Savannah River fish. No apparent trends can be discerned from these data. This is because there is large variability in the annual strontium- 90 and cesium- 137 concentrations measured in fish from the same location due to differences in

\begin{tabular}{|c|c|c|}
\hline $\begin{array}{l}\text { Table 6-5 } \\
\text { Potential Lifetime Ris } \\
\text { Standards }\end{array}$ & otion of Savannah & sh Compared to Dose \\
\hline & $\begin{array}{l}\text { Committed Dose } \\
\text { (mrem) }\end{array}$ & $\begin{array}{l}\text { Potential Risk } \\
\text { (unitless) }\end{array}$ \\
\hline 2006 Savannah River & & \\
\hline 1-Year Exposure & 0.24 & $1.8 \mathrm{E}-07$ \\
\hline 30-Year Exposure & 7.2 & $5.4 \mathrm{E}-06$ \\
\hline 50-Year Exposure & 12.0 & $9.0 \mathrm{E}-06$ \\
\hline Dose Standard & & \\
\hline 100-Mrem/Year All & & \\
\hline 1-Year Exposure & 100 & 7.3E-05 \\
\hline 30-Year Exposure & 3,000 & $2.2 \mathrm{E}-03$ \\
\hline 50-Year Exposure & 5,000 & 3.7E-03 \\
\hline $\begin{array}{l}\text { a It should be noted that a } \\
\text { actual people who have } \\
\text { atomic bomb survivors. F } \\
\text { estimated by extrapolatir } \\
\text { no-threshold model. Hon } \\
\text { radiation doses because } \\
\text { current scientific method }\end{array}$ & $\begin{array}{l}\text { are based on observe } \\
\text { e than } 10,000 \text { mrem) } \\
\text { oses (less than } 10,00 \\
\text { ects at high doses to } \\
\text { ealth effects have not } \\
\text { not exist or are so lo }\end{array}$ & $\begin{array}{l}\text { onmented health effects to } \\
\text { are theoretical and are } \\
\text { tose region by using a linear, } \\
\text { served consistently at low } \\
\text { y are undetectable by }\end{array}$ \\
\hline
\end{tabular}




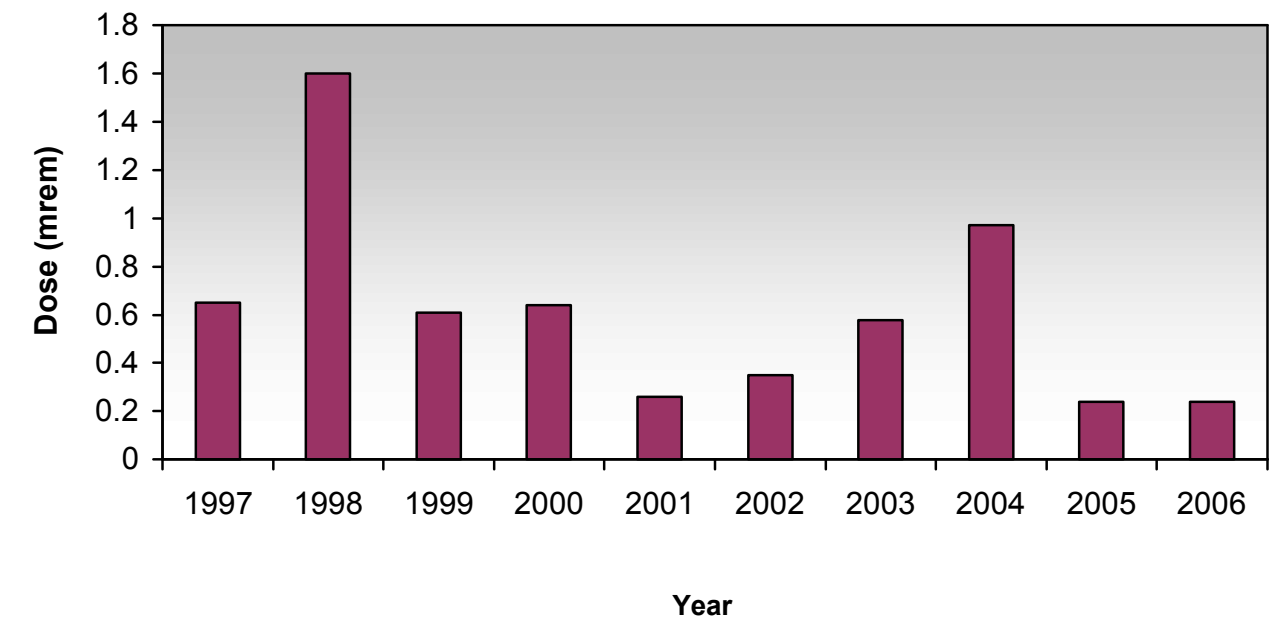

Figure 6-2 Ten-Year History of SRS Creek Mouth Fisherman's Dose

- the size of the fish collected each year

- their mobility and location within the stream mouth from which they are collected

- the time of year they are collected

- the amount of strontium-90 and cesium-137 available in the water and sediments at the site stream mouths - caused by annual changes in stream flow rates (turbulence) and water chemistry

As indicated in table 6-5, the 50-year maximum potential lifetime risk from consumption of SRS creek mouth fish was 9.0E-06, which is below the 50-year risk (3.7E-03) associated with the 100-mrem-per-year dose standard. According to EPA practice, if a potential lifetime risk is calculated to be less than 1.0E-06 (i.e., one additional case of cancer over what would be expected in a group of 1,000,000 people), then the risk is considered minimal and the corresponding contaminant concentrations are considered negligible. If a calculated risk is more than 1.0E-04 (one additional case of cancer in a population of $10,000)$, then some form of corrective action or remediation usually is required. However, if a calculated risk falls between 1.0E-04 and 1.0E-06, which is the case with the maximum potential lifetime risks from the consumption of Savannah River fish, then the risk may be deemed acceptable if it is kept as low as reasonably achievable (ALARA), although actions to further reduce this risk can be considered.

At SRS, the environmental ALARA program [SRS EM Program, 2001] is in place to ensure that the potential risk from site radioactive liquid effluents (and, therefore, from consumption of Savannah River fish) is kept ALARA. 


\section{Radiation Dose to Aquatic and Terrestrial Biota}

DOE Order 5400.5 establishes an interim dose standard for protection of native aquatic animals. The absorbed dose limit to these organisms is $1.0 \mathrm{rad}$ per day ( $0.01 \mathrm{~Gy}$ per day) from exposure to radioactive material in liquid effluents released to natural waterways.

\section{DOE Biota Concentration Guides}

For 2006, a screening of biota doses at SRS was performed using the RESRAD-Biota model (version 1.2), which is based on the DOE standard entitled A Graded Approach for Evaluating Radiation Doses to Aquatic and Terrestrial Biota [DOE, 2002].

The aquatic systems evaluation includes exposures to primary (herbivores) and secondary (predators) aquatic animals, and the biota concentration guides (BCGs) are based on the 1.0-rad-per-day dose limit. Aquatic plants are not considered.

The terrestrial systems evaluation includes exposures to terrestrial plants and animals and is based on a 10-rad-per-day dose limit for plants and a 0.1-rad-per-day dose limit for animals. For the aquatic systems evaluation portion of the BCGs, an initial screening was performed using maximum radionuclide concentration data for the 10 Environmental Permitting and Monitoring (EPM) stream sampling locations from which co-located water and sediment samples are collected. An exception to this was made for sample location FM-2B (located on Four Mile Creek between F-Area and H-Area) because of its historically high cesium and tritium concentration levels. This location was included in the initial screening even though no co-located sediment sample is collected there.

The combined water-plus-sediment BCG sum of the ratios was used for the aquatic systems evaluation. A sum of the ratios less than one indicates the sampling site has passed the initial pathway screen. For the terrestrial systems evaluation portion of the BCGs, an initial screening was performed using concentration data from the five EPM onsite radiological soil sampling locations. Only one soil sample per year is collected from each location.

For 2006, stream sampling locations R-1 (located adjacent to R-Reactor near the center of SRS), FM-A7, and FM-2B failed the initial aquatic systems screen. These locations failed because of relatively high maximum concentrations of cesium-137 in the water and sediment samples. All other locations, including the five soil sampling locations used for the terrestrial assessment, passed. For the three locations that failed, an additional assessment was performed using annual average radionuclide concentrations measured in the water and sediment samples. All locations passed this secondary screen (the sum of the ratios of each was less than 1.0). 



\title{
Groundwater
}

\author{
Dan Wells \\ Environmental Services Section
}

Bob Hiergesell

Savannah River National Laboratory

Environmental Analysis and Performance Modeling

Goundwater protection at the Savannah River Site (SRS) has evolved into a program

Jwith the following primary components:

- Protect groundwater by good practices in managing chemicals and work.

- Monitor groundwater to identify areas of contamination.

- Remediate contamination as needed.

- Use groundwater wisely to conserve.

SRS operations have contaminated groundwater around certain waste disposal facilities. Extensive monitoring and remediation programs are tracking and cleaning up the contamination. Remediation includes (1) the closing of waste sites to reduce the migration of contaminants into groundwater and (2) the active treatment of contaminated water.

No offsite wells have been contaminated by the migration of SRS groundwater.

This chapter describes SRS's groundwater environment and the programs in place for investigating, monitoring, remediating, and using the groundwater.

\section{Groundwater at SRS}

SRS is underlain by sediment of the Atlantic Coastal Plain. The Atlantic Coastal Plain consists of a southeast-dipping wedge of unconsolidated sediment that extends from its contact with the Piedmont Province at the Fall Line to the edge of the continental shelf. The sediment ranges from Late Cretaceous to Miocene in age and comprises layers of sand, muddy sand, and clay with subordinate calcareous sediments. It rests on crystalline and sedimentary basement rock.

Water flows easily through the sand layers but is retarded by less permeable clay beds, creating a complex system of aquifers. Operations during the life of SRS have resulted in contamination migrating into groundwater at various site locations, predominantly in the central areas of the site. The ongoing movement of water into the ground, through the aquifer system, and then into streams and lakes - or even into deeper aquifers-continues to carry contamination along with it, resulting in spreading plumes. 


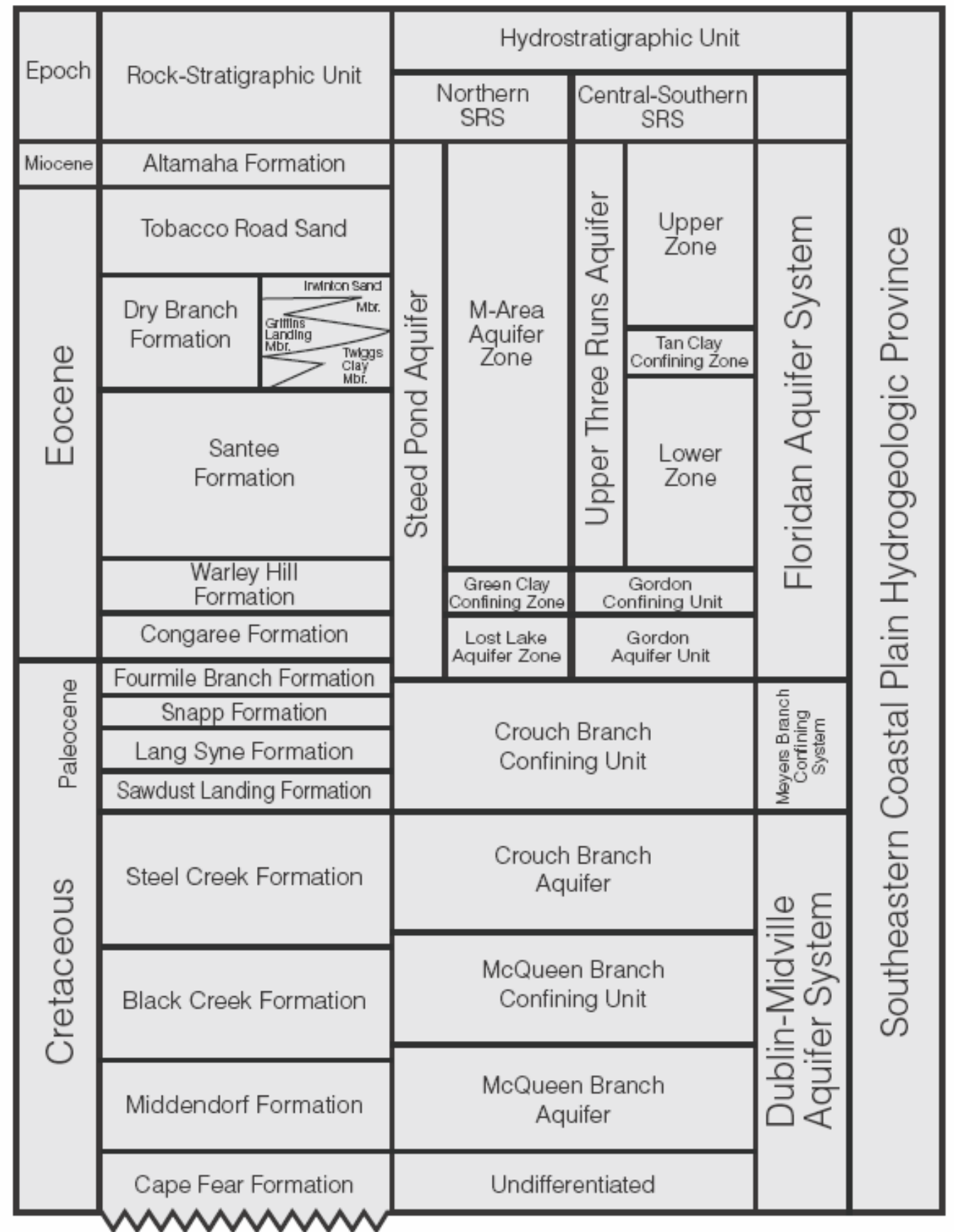

Paleozoic Crystalline

Basement Rock or Triassic

Piedmont Hydrogeologic Province

Newark Supergroup

Modified from Aadland et al., 1995, and Fallaw and Price, 1995

Figure 7-1 Hydrostratigraphic Units at SRS 
The hydrostratigraphy of SRS has been subject to several classifications. The hydrostratigraphic classification established in Aadland et al., 1995, and in Smits et al., 1996, is widely used at SRS and is regarded as the current SRS standard. This system is consistent with the one used by the U.S. Geological Survey (USGS) in regional studies that include the area surrounding SRS [Clarke and West, 1998]. Figure 7-1 is a chart that indicates the relative position of hydrostratigraphic units and relates hydrostratigraphic units to corresponding lithologic units at SRS and to the geologic time scale. This chart was modified from Aadland et al., 1995, and Fallaw and Price, 1995.

The hydrostratigraphic units of primary interest beneath SRS are part of the Southeastern Coastal Plain Hydrogeologic Province. Within this sequence of aquifers and confining units are two principal subcategories, the overlying Floridan Aquifer System and the underlying Dublin-Midville Aquifer System. These systems are separated from one another by the Meyers Branch Confining System. In turn, each of the systems is subdivided into two aquifers, which are separated by a confining unit.

In the central to southern portion of SRS, the Floridan Aquifer System is divided into the overlying Upper Three Runs Aquifer and the underlying Gordon Aquifer, which are separated by the Gordon Confining Unit. North of Upper Three Runs Creek, these units are collectively referred to as the Steed Pond Aquifer, in which the Upper Three Runs Aquifer is called the M-Area Aquifer zone, the Gordon Aquifer is referred to as the Lost Lake Aquifer zone, and the aquitard that separates them is referred to as the Green Clay confining zone unit within which the water table usually occurs at SRS; hence, it is referred to informally as the "water table" aquifer. The water table surface can be as deep as 160 feet below ground surface (bgs), but intersects the ground surface in seeps along site streams. The top of the Gordon Aquifer typically is encountered at depths of 150-250 feet bgs. The Dublin-Midville Aquifer System is divided into the overlying Crouch Branch Aquifer and the underlying McQueen Branch Aquifer, which are separated by the McQueen Branch Confining Unit. The Crouch Branch Aquifer and McQueen Branch Aquifer are names that originated at SRS [Aadland et al., 1995]. These units are equivalent to the Dublin Aquifer and the Midville Aquifer, which are names originating with the USGS [Clarke and West, 1998]. The top of the Crouch Branch Aquifer typically is encountered at depths of 350-500 feet bgs. The top of the McQueen's Branch Aquifer typically is encountered at depths of $650-750$ feet bgs.

Figure 7-2 is a three-dimensional block diagram of the hydrogeologic units at SRS and the generalized groundwater flow patterns within those units. These units are from shallowest to deepest: the Upper Three Runs/Steed Pond Aquifer (or water table aquifer), the Gordon/Lost Lake Aquifer, the Crouch Branch Aquifer, and the McQueen Branch Aquifer.

Groundwater recharge is a result of the infiltration of precipitation at the land surface; the precipitation moves vertically downward through the unsaturated zone to the water table. Upon entering the saturated zone at the water table, water moves predominantly in a horizontal direction toward local discharge zones along the headwaters and midsections of streams, while some of the water moves into successively deeper aquifers. The water lost to successively deeper aquifers also migrates laterally within those units toward the more distant regional discharge zones. These typically are located along the major streams and rivers in the area, such as the Savannah River. Groundwater movement within these units is extremely slow when compared to surface water flow rates. Groundwater velocities also 
are quite different between aquitards and aquifers, ranging at SRS from several inches to several feet per year in aquitards and from tens to hundreds of feet per year in aquifers.

Monitoring wells are used extensively at SRS to assess the effect of site activities on groundwater quality. Most of the wells monitor the upper groundwater zone, although wells in lower zones are present at the sites with the larger groundwater contamination plumes. Groundwater in some areas contains one or more constituents at or above the levels of the drinking water standards of the U.S. Environmental Protection Agency (EPA). These areas can be seen in figure 15 of the "SRS Maps" appendix on the CD accompanying this report.
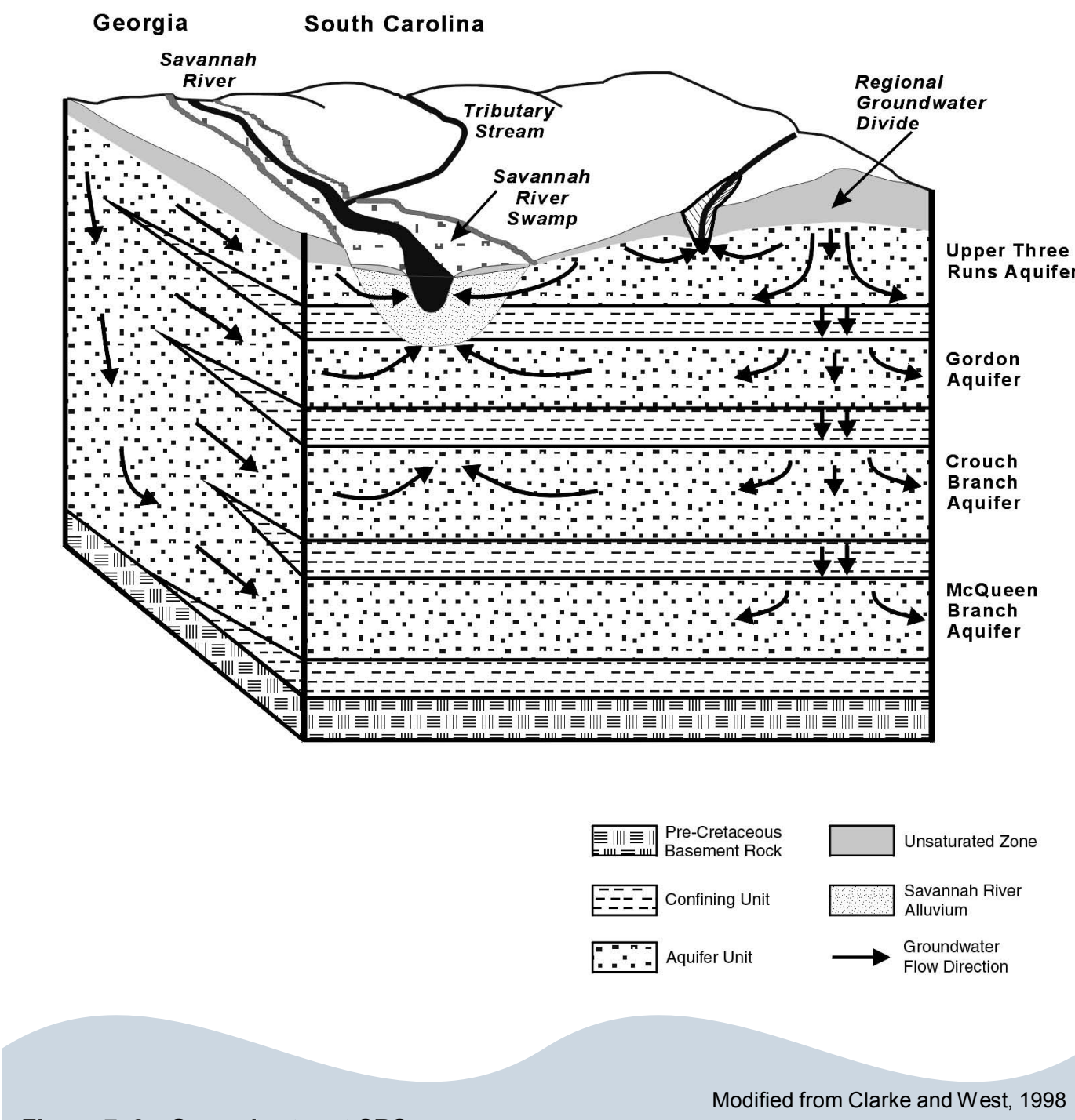

Figure 7-2 Groundwater at SRS

The groundwater flow system as SRS consists of four major aquifers separated by confining unit. Flow in recharge areas generally migrates downward as well as laterally-eventually either discharging into the Savannah River and its tributaries or migrating into the deeper regional flow system. 


\section{Groundwater Protection Program at SRS}

The SRS groundwater program was audited by both the U.S. Department of Energy (DOE) and WSRC in 2000 and 2001. Findings of these assessments have resulted in an ongoing evaluation of the site groundwater program's goals and priorities. It has been determined that a groundwater protection program designed to meet federal and state laws/regulations, DOE orders, and site policies/procedures should contain the following elements:

- investigating site groundwater

- using site groundwater

- protecting site groundwater

- remediating contaminated site groundwater

- monitoring site groundwater

SRS identified specific program goals in each of these areas to maintain its commitment to a groundwater program that protects human health and the environment. Groundwater monitoring is a key tool used in each of the first four elements, and monitoring results form the basis for evaluations that are reported to site stakeholders.

\section{Investigating SRS Groundwater}

An extensive program is in place at SRS to acquire new data and information on the groundwater system. This program is multifaceted and is conducted across departmental boundaries at the site because of the different charters and mandates of these

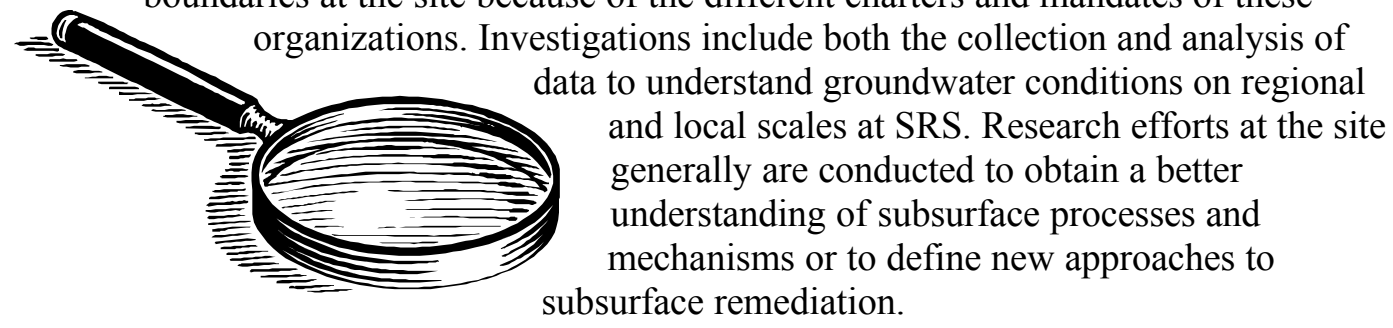

Investigative efforts focus on the collection and analysis of data to characterize the groundwater flow system. Characterization efforts at SRS include the following activities:

- collection of geologic core material and performance of seismic profiles to better delineate subsurface structural features

- installation of wells to allow periodic collection of both water levels and groundwater samples at strategic locations

- development of water table and potentiometric maps to delineate the direction of groundwater movement in the subsurface

- performance of various types of tests to obtain in situ estimates of hydraulic parameters needed to estimate groundwater velocities

Analysis of data on the regional scale is needed to provide a broad understanding of groundwater movement patterns at SRS that can be used as a framework to better understand the migration of contaminants at the local scale near individual waste units. Surface water flow characteristics also are defined at the site on the regional scale and are 
significant to risk analyses because perennial streams are the receptors of groundwater discharge - some of which contains contaminants from SRS waste units. Because the site boundary does not represent a groundwater boundary, regional studies are helpful in understanding the movement of groundwater both onto the site from the surrounding area and vice versa.

The collection and analysis of data describing subsurface hydrogeologic conditions at or near individual waste units are needed to design effective remediation systems.

Characterization embraces both traditional and innovative technologies to accomplish this goal. The installation of monitoring wells and piezometers is a traditional investigative method to allow the collection of (1) water levels, which are used to define flow directions, and (2) groundwater samples, which are analyzed to monitor contaminant plume migration within the groundwater flow system. Geophysical data acquired during well installation are used to delineate the subsurface hydrostratigraphy. Examples of newer technologies include the use of

- direct-push technology, such as the cone penetrometer, to collect one-time groundwater samples at investigation sites and to help establish hydrostratigraphic contacts

- the "rotosonic" method for bore holes to collect cores and install wells

Models have been used extensively as analytical tools at SRS for both regional and local investigations. Models have been utilized for a variety of reasons, but primarily to (1) define the regional groundwater movement patterns at SRS and the surrounding areas, (2) enhance the understanding of contaminant migration in the subsurface, and (3) support the design of remediation systems. At SRS, major groundwater modeling efforts have focused on A/M-Area, F-Area, H-Area, the Burial Ground Complex, and several of the reactor areas where the most extensive subsurface contamination is known to exist.

Research on groundwater issues is conducted at SRS to obtain a better understanding of subsurface mechanisms, such as (1) the interaction of contaminants with the porous media matrix and (2) the factors that impact the rate of migration of contaminants within the groundwater flow system. Research to address relevant issues often is conducted through cooperative studies with investigators at various public universities and private companies, while other efforts are conducted exclusively by SRS employees.

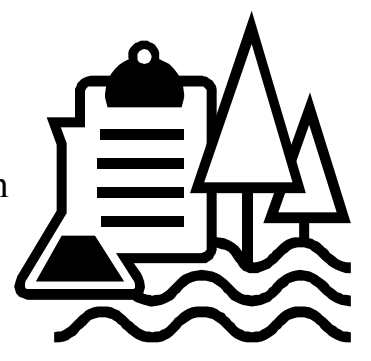

\section{Special Groundwater Study}

A part of the SRS perimeter that has received special monitoring attention is across the Savannah River in Georgia's Burke and Screven counties. Since 1988, it has been speculated that tritiated groundwater from SRS could flow under the river and find its way into Georgia wells. Considerable effort has been directed at assessing the likelihood of transriver flow, and the USGS and the Georgia Department of Natural Resources have drilled 44 wells (figure 21 in "SRS Maps" appendix on CD accompanying this report).

As part of the data collection and analysis, the USGS developed a numerical model in 1997-98 to assess the possibility for such transriver flow to occur. Development of the model — and the resulting analyses — is documented in Clarke and West, 1998. 


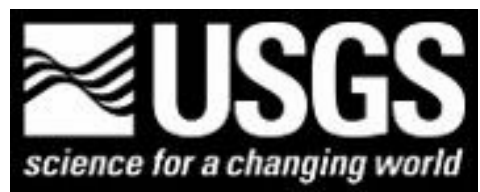

The model represented the regional groundwater flow system in seven layers corresponding to the underlying hydrostratigraphic units, which was regarded as sufficiently detailed to evaluate whether groundwater originating at SRS could possibly flow beneath the Savannah River into Georgia. An extensive effort was undertaken to calibrate the model to water-level measurements obtained from wells on both sides of the Savannah River and screened in each of the hydrostratigraphic units represented in the model. The model concluded that groundwater movement in all hydrostratigraphic units proceeds laterally toward the Savannah River from both South Carolina and Georgia, and discharges into the river.

Once the model was calibrated, the USGS employed particle-track analysis to delineate areas of potential transriver flow, which can occur in either an eastward or westward direction. The model indicated that all locations of transriver flow are restricted to the Savannah River's floodplain, where groundwater passes immediately prior to discharging into the river. Whether the transriver flow is eastward or westward depends primarily on the position of the Savannah River as it meanders back and forth within the floodplain.

With respect to "westward" transriver flow, the USGS model indicates that it primarily occurs in locations south of SRS and within the deeper aquifers (Crouch Branch and McQueen Branch). Particle-tracking analysis of westward transriver flow in these aquifers indicates that the groundwater crossing from South Carolina into Georgia originates as recharge in upland areas well to the east and south of SRS.

One of the main purposes of the study was to identify whether groundwater originating at SRS could eventually flow into Georgia prior to discharging into the Savannah River. The model identified one area (less than one square mile) of westward transriver flow that has a recharge area located within SRS, and that conceivably could receive tritium or other contaminants from SRS as a result. The one-square-mile area occurs immediately adjacent to the Savannah River, where groundwater within the Gordon Aquifer flows immediately prior to discharging into the river.

Particle tracking indicates that recharge zones associated with the one square mile are located in the upland areas between D-Area and K-Area. There is no known subsurface contamination at these recharge zones. Travel times associated with the particles were calculated to range from 90 to 820 years; however, actual travel times are longer because the USGS study did not account for vertical downward groundwater movement from the water table to the Gordon Confining Unit at the recharge locations. It is important to note that the range of travel times represents seven to 66 half-lives of tritium (12.33 years), suggesting that even if tritium contamination existed at the recharge areas, it likely would decay away prior to discharging into the Savannah River.

The USGS, in cooperation with DOE, completed additional work in 2006 to determine the occurrence of transriver flow under 2002 and future hydrologic conditions. This work included an update to the original groundwater model to incorporate boundary conditions representative of 2002 - a time of severe drought in the SRS vicinity-as well as conditions projected to occur in 2020 . The models then were utilized to evaluate several hypothetical groundwater extraction scenarios to determine their impact on westward 
transriver flow that originates at SRS. Scenarios included groundwater extraction rates realized during droughts, as well as one in which groundwater extraction at SRS was discontinued. The year 2020 was selected to define a scenario that represented the maximum plausible groundwater extraction rate in the area. Projections of increased water use for municipal and agricultural purposes were extrapolated from the present time to 2020 for use in this scenario.

With respect to the only location of westward transriver flow that has a recharge area within SRS, the evaluations of the hypothetical pumping scenarios indicated that only a slight impact was incurred. While the updated model did not change the location of the recharge areas at SRS, the shortest travel time between the recharge area and the zone of transriver flow (as determined by reverse particle tracking) was reported to be 79 years. This is compared to the prior shortest estimate of 90 years. The median groundwater travel times for particles released under each of the four groundwater extraction scenarios was reported to range from 366 to 507 years. It should be emphasized that these transit times do not include the time required for groundwater to migrate vertically downward across the uppermost aquifer (i.e., at the recharge area), thus the actual groundwater travel times could be up to several decades longer than what is reported. The final results of this investigation are documented in a formal USGS report completed in 2006 [Cherry, 2006].

Despite the fact that the USGS groundwater model indicates there is no mechanism by which transriver flow could contaminate Georgia wells, SRS continues to maintain and sample the Georgia monitoring wells annually. In 2006, none of the tritium results exceeded 1,000 $\mathrm{pCi} / \mathrm{L}$. Levels this low are consistent with aquifer recharge from rainfall. EPA's maximum contaminant level for tritium is $20,000 \mathrm{pCi} / \mathrm{L}$.

\section{Using SRS Groundwater}

SRS derives its own drinking and process water supply from groundwater. The site ranks as South Carolina's largest selfsupplied industrial consumer of groundwater, utilizing approximately 3.9 million gallons per day. SRS domestic and process water systems are supplied from a network of approximately 40 wells in widely scattered locations across the

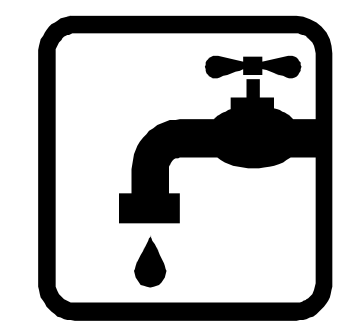
site, of which eight supply the primary drinking water system for the site. Treated well water is supplied to the larger site facilities by the A-Area, D-Area, and K-Area domestic water systems. Each system has wells, a treatment plant, elevated storage tanks, and distribution piping. The wells range in capacity from 200 to 1,500 gallons per minute.

The A-Area, D-Area, and K-Area systems supply an average of 1.1 million gallons per day of domestic water to customers in these areas. The domestic water systems supply site drinking fountains, lunchrooms, restrooms, and showering facilities with water meeting state and federal drinking water quality standards. Process water is used for equipment cooling and facility washdown water, and as makeup water for site cooling towers and production processes.

The South Carolina Department of Health and Environmental Control (SCDHEC) periodically samples the large- and small-system wells for Safe Drinking Water Act contaminants. An unscheduled biannual SCDHEC sanitary survey also is performed. 
In 1983, SRS began reporting its water usage annually to the South Carolina Water Resources Commission (and later to SCDHEC). Since that time, the amount of groundwater pumped on site has dropped from 10.8 million gallons per day during 19831986 to 3.9 million gallons per day in 2006. The majority of this decrease is attributable to the consolidation of site domestic water systems, which was completed in 1997. Thirteen separate systems, each with its own high-capacity supply wells, were consolidated into three systems located in A-Area, D-Area, and K-Area. This greatly reduced the amount of excess water being pumped to waste. Site facility shutdowns and reductions in population also were contributing factors.

The three systems draw water from the Crouch Branch and McQueen's Branch Aquifers. The amount of groundwater pumped at SRS has had only localized effects on water levels in these aquifers, and it is unlikely that water usage at the site will cause drawdown problems that could impact surrounding communities.

The process water systems in A-Area, F-Area, H-Area, K-Area, L-Area, S-Area, and TNXArea meet site demands for boiler feedwater, equipment cooling water, facility washdown water, and makeup water for cooling towers, fire storage tanks, chilled-water-piping loops, and site test facilities. These systems are supplied from dedicated process water wells ranging in capacity from 100 to 1,500 gallons per minute. In K-Area, the process water system is supplied from the domestic water wells. At some locations, the process water wells pump to ground-level storage tanks, where the water is treated for corrosion control. At other locations, the wells directly pressurize the process water distribution piping system without supplemental treatment.

The site groundwater protection program integrates information learned about the properties of SRS aquifers with site demand for drinking and process water. SRS ensures a high level of drinking water supply protection by (1) monitoring above and beyond SCDHEC requirements and (2) periodically evaluating production wells.

\section{Protecting SRS Groundwater}

SRS is committed to protecting the groundwater resource beneath the site. A variety of activities contribute to this goal, including

- construction, waste management, and monitoring efforts to prevent or control sources of groundwater contamination

- monitoring programs (both groundwater and surface water) to detect contamination

- a strong groundwater cleanup program through the Soil and Groundwater Closure Projects (SGCP) Department

Monitoring around known waste disposal sites and operating facilities provides the best means to detect and track groundwater contamination. To detect contamination from as-yet undiscovered sites, SRS depends on a sitewide groundwater monitoring and protection effort - the site Groundwater Surveillance Monitoring Program (GSMP). This program is an upgraded replacement of the site screening program.

Monitoring wells and production wells that no longer are needed should be properly abandoned. In 2006, SRS abandoned 30 monitoring wells, 35 remediation wells, and two production wells. Additional abandonments are planned for 2007. 
One goal of the GSMP is to protect potential offsite receptors from contamination by detecting contamination in time to apply appropriate corrective actions. SRS is a large site, and most groundwater contamination is located in its central areas. However, the potential for offsite migration exists, and the consequences of such an outcome are serious enough to warrant a comprehensive prevention program.

SRS has evaluated flow in each aquifer and determined where there is potential for flow across the site boundary. This gives a conservative indication of where offsite contamination might be possible and allows for a focused monitoring effort in those few areas. Another pathway for existing groundwater contamination to flow offsite is by discharge into surface streams and subsequent transport into the Savannah River. SRS monitors site streams for contamination, and new wells have been installed in recent years along several site streams to (1) detect contamination before it enters the stream and (2) assess the contamination's concentration in groundwater.

The SRS groundwater monitoring program gathers information to determine the effect of site operations on groundwater quality. The program is designed to

- assist the site in complying with environmental regulations and DOE directives

- provide data to identify and monitor constituents in the groundwater

- permit characterization of new facility locations to ensure that they are suitable for the intended facilities

- $\quad$ support basic and applied research projects

\section{Sample Scheduling and Collection}

The Geochemical Monitoring group and the Environmental Services Section schedule groundwater sampling either in response to specific requests from SRS personnel or as part of their ongoing groundwater monitoring program. These groundwater samples provide data for reports required by federal and state regulations and for internal reports and research projects. The groundwater monitoring program schedules wells to be sampled at intervals ranging from quarterly to triennially.

Constituents that may be analyzed are commonly imposed by permit or work plan approval. These include metals, field parameters, and suites of herbicides, pesticides, volatile organics, and others. Radioactive constituents that may be analyzed by request include gross alpha and beta measurements, gamma emitters, iodine-129, strontium-90, radium isotopes, uranium isotopes, and other alpha and beta emitters.

Groundwater samples are collected from monitoring wells, generally with either pumps or bailers dedicated to the well to prevent cross-contamination among wells. Occasionally, portable sampling equipment is used; this equipment is decontaminated between wells.

Sampling and shipping equipment and procedures are consistent with EPA, SCDHEC, and U.S. Department of Transportation guidelines. EPA-recommended preservatives and samplehandling techniques are used during sample storage and transportation to both onsite and offsite analytical laboratories. Potentially radioactive samples are screened for total activity (alpha and beta emitters) prior to shipment to determine appropriate packaging and labeling requirements.

Deviations (caused by dry wells, inoperative pumps, etc.) from scheduled sampling and analysis for 2006 were entered into the site's groundwater database and issued in appropriate reports. 
The groundwater monitoring program at SRS includes two primary components: (1) waste site/remediation groundwater monitoring, overseen by the Geochemical Monitoring group of SGCP, and (2) groundwater surveillance monitoring, conducted by the Environmental Services Section. To assist other departments in meeting their responsibilities, personnel of both organizations provide the services for installing monitoring wells, collecting and analyzing samples, and reporting results.

The WSRC Environmental Compliance Manual (WSRC 3Q) provides details about the following aspects of the groundwater monitoring program:

- well siting, construction, maintenance, and abandonment

- sample planning

- $\quad$ sample collection and field measurements

- analysis

- data management

- related publications, files, and databases

Monitoring data are evaluated each year to identify unexpected results in any site wells that might indicate new or changing groundwater contamination.

\section{Remediating Contaminated SRS Groundwater}

SRS has maintained an environmental remediation effort for many years. SGCP personnel manage the cleanup of contaminated groundwater associated with Resource Conservation and Recovery Act (RCRA) hazardous waste management facilities or Federal Facility Act units. Their mission is to aggressively manage the inactive waste site and groundwater cleanup program so that

- schedules for environmental agreements are consistently met

- the utilization of financial and technology resources is continually improved

- the overall risk posed by existing contaminated sites is continually reduced

The SGCP strategy revolves around developing an appropriate regulatory framework for each waste site, assessing the degree and extent of contamination, and remediating the contaminated groundwater to its original beneficial use. Remedial technologies being used include pump and treat, in situ $\mathrm{pH}$ adjustment, steam injection, phytoremediation, and barrier wall construction. In cases where remediation to background quality is impractical,

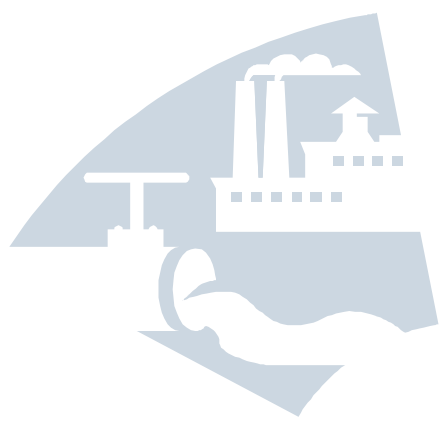
the intent is to prevent plume migration and exposure and to evaluate alternate methods of risk reduction. Major 2006 accomplishments include the following:

- Work on a 75-acre low-permeability cover over the Old Radioactive Waste Burial Ground neared completion.

- Construction was completed on an electrical resistance heating/soil vapor extraction system that will clean up a trichloroethylene source in the vadose zone near $\mathrm{C}$ Reactor. 
- The Dynamic Underground Stripping system at the M-Area Settling basin continued to heat the subsurface by injecting large volumes of steam, which strips solvents from subsurface sediments. Several parcels have been adequately heated, and extraction of the stripped solvents ranges from 2,400 to 9,400 pounds per week.

\section{Monitoring SRS Groundwater}

The first priority of the groundwater monitoring program at SRS is to ensure that contamination is not being transported from the site by groundwater flow. Contaminated groundwater at SRS discharges into site streams or the Savannah River. Nowhere have offsite wells been contaminated by groundwater from SRS, and only a few site locations have groundwater with even a remote chance of contaminating such wells.

One of these locations is near A-Area/M-Area, the site of a large chlorinated solvent plume. This area's groundwater monitoring program uses more than 200 wells, and some of the contaminated wells lie within a half-mile of the site's northeastern boundary. While it is believed that the major component of groundwater flow is not directly toward the site boundary, flow in the area is complex and difficult to predict. For this reason, particular attention is paid to data from wells along the site boundary and from those between AArea/M-Area and the nearest population center, Jackson, South Carolina (figure 20 in the "SRS Maps" appendix on the CD accompanying this report). During 2006, no chlorinated organics were detected in any of these wells.

Although contaminated groundwater in most SRS areas does not approach the site boundary, it does have the potential to impact site streams. For this reason-and because of the need to meet the requirements of various environmental regulations-extensive monitoring is conducted around SRS waste sites and operating facilities, regardless of their proximity to the boundary.

Table 7-1 presents a general summary of the most contaminated groundwater conditions at SRS, based on 2005 and 2006 monitoring data. The table shows the 2006 maximum concentrations for major constituents in the SRS areas that have contaminated groundwater - and how these concentrations compare to the drinking water standards and the 2005 maximums. As shown in the table, the two major contaminants of concern in groundwater are (1) common degreasers (trichloroethylene and perchloroethylene) and (2) radionuclides (tritium and gross alpha and nonvolatile beta emitters). In most cases, the maximum concentrations did not change significantly between 2005 and 2006.

Table 7-1 also shows where the contaminated water most likely will outcrop. By the time the groundwater reaches a stream, it generally is much less contaminated because of natural attenuation processes, such as dilution, biodegradation, and radioactive decay. As stated above, results in the table are maximum values generally associated with wells very close to contaminant source areas, where little attenuation has taken place.

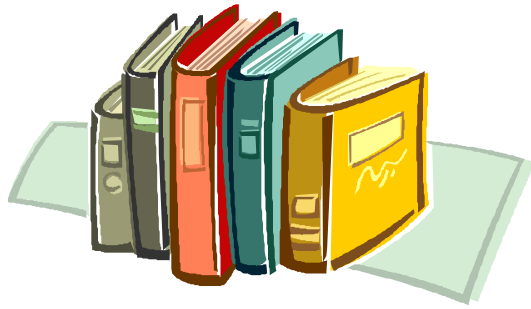

For details about this monitoring and the conditions at individual sites, one should refer to site-specific documents, such as RCRA corrective action reports or RCRA/Comprehensive Environmental Response, Compensation, and Liability Act RCRA Facility Investigation/Remedial Investigation reports. 
Table 7-1

Summary of Maximum Groundwater Monitoring Results for Major Areas Within SRS, 2005-2006

\begin{tabular}{|c|c|c|c|c|c|c|}
\hline Location & $\begin{array}{l}\text { Major } \\
\text { Contaminants }\end{array}$ & Units & $\begin{array}{l}2005 \\
\text { Maximum }\end{array}$ & $M C L^{a}$ & $\begin{array}{l}2006 \\
\text { Maximum }\end{array}$ & $\begin{array}{l}\text { Likely } \\
\text { Outcrop Point }\end{array}$ \\
\hline $\begin{array}{l}\text { A-Area/ } \\
\text { M-Area }\end{array}$ & $\begin{array}{l}\text { TCE } \\
\text { PCE }\end{array}$ & $\begin{array}{l}\mathrm{ppb} \\
\mathrm{ppb}\end{array}$ & $\begin{array}{l}28,400 \\
127,000\end{array}$ & $\begin{array}{l}5 \\
5\end{array}$ & $\begin{array}{l}33,000 \\
93,300\end{array}$ & $\begin{array}{l}\text { Tims Branch/ } \\
\text { Upper Three } \\
\text { Runs Creek in } \\
\text { Swamp in West }\end{array}$ \\
\hline C-Area & $\begin{array}{l}\text { TCE } \\
\text { Tritium }\end{array}$ & $\begin{array}{l}\mathrm{ppb} \\
\mathrm{pCi} / \mathrm{L}\end{array}$ & $\begin{array}{l}1,611 \\
4,851,000\end{array}$ & $\begin{array}{l}5 \\
20,000\end{array}$ & $\begin{array}{l}11,600 \\
1,130,000\end{array}$ & $\begin{array}{l}\text { Tributaries of } \\
\text { Fourmile Branch }\end{array}$ \\
\hline D-Area & $\begin{array}{l}\text { TCE } \\
\text { Tritium }\end{array}$ & $\begin{array}{l}\mathrm{Ppb} \\
\mathrm{pCi} / \mathrm{L}\end{array}$ & $\begin{array}{l}490 \\
1,030,000\end{array}$ & $\begin{array}{l}5 \\
20,000\end{array}$ & $\begin{array}{l}280 \\
667,000\end{array}$ & $\begin{array}{l}\text { Savannah River } \\
\text { Swamp }\end{array}$ \\
\hline E-Area & $\begin{array}{l}\text { Tritium } \\
\text { TCE }\end{array}$ & $\begin{array}{l}\mathrm{pCi} / \mathrm{L} \\
\mathrm{PPB}\end{array}$ & $\begin{array}{l}45,700,00 \\
570\end{array}$ & $\begin{array}{l}20,000 \\
5\end{array}$ & $\begin{array}{l}33,600,000 \\
750\end{array}$ & $\begin{array}{l}\text { Upper Three } \\
\text { Runs/Crouch } \\
\text { Branch in North; } \\
\text { Fourmile Branch } \\
\text { in South }\end{array}$ \\
\hline F-Area & $\begin{array}{l}\text { TCe } \\
\text { Tritium } \\
\text { Gross alpha Beta }\end{array}$ & $\begin{array}{l}\text { ppb } \\
\text { pCi/L } \\
\text { pCi/L } \\
\text { pCi/L }\end{array}$ & $\begin{array}{l}55 \\
435,000 \\
103 \\
359\end{array}$ & $\begin{array}{l}5 \\
20,000 \\
15 \\
4 \text { mrem/yr }{ }^{a}\end{array}$ & $\begin{array}{l}78.9 \\
91,500 \\
2030 \\
2620\end{array}$ & $\begin{array}{l}\text { Upper Three } \\
\text { Runs/Crouch } \\
\text { Branch in North; } \\
\text { Fourmile Branch } \\
\text { in South }\end{array}$ \\
\hline $\begin{array}{l}\text { F-Area } \\
\text { Seepage } \\
\text { Basin }\end{array}$ & $\begin{array}{l}\text { Tritium } \\
\text { Gross alpha } \\
\text { Beta }\end{array}$ & $\begin{array}{l}\mathrm{pCi} / \mathrm{L} \\
\mathrm{pCi} / \mathrm{L} \\
\mathrm{pCi} / \mathrm{L}\end{array}$ & $\begin{array}{l}7,660,000 \\
781 \\
3,030\end{array}$ & $\begin{array}{l}20,000 \\
15 \\
4 \mathrm{mrem} / \mathrm{hr}^{\mathrm{a}}\end{array}$ & $\begin{array}{l}7,140,000 \\
627 \\
2360\end{array}$ & Fourmile Branch \\
\hline H-Area & $\begin{array}{l}\text { Tritium } \\
\text { Gross alpha } \\
\text { Beta }\end{array}$ & $\begin{array}{l}\mathrm{pCi} / \mathrm{L} \\
8.46 \\
81.5\end{array}$ & $\begin{array}{l}54,300 \\
8.46 \\
81.5\end{array}$ & $\begin{array}{l}20,000 \\
15 \\
4 \mathrm{mrem} / \mathrm{yr}^{\mathrm{a}}\end{array}$ & $\begin{array}{l}80,400 \\
98 \\
116\end{array}$ & $\begin{array}{l}\text { Upper Three } \\
\text { Runs/Crouch } \\
\text { Branch in North; } \\
\text { Fourmile Branch } \\
\text { in South }\end{array}$ \\
\hline $\begin{array}{l}\text { H-Area } \\
\text { Seepage } \\
\text { Basins }\end{array}$ & $\begin{array}{l}\text { Tritium } \\
\text { Gross alpha } \\
\text { Beta }\end{array}$ & $\begin{array}{l}\mathrm{pCi} / \mathrm{L} \\
\mathrm{pCi} / \mathrm{L} \\
\mathrm{pCi} / \mathrm{L}\end{array}$ & $\begin{array}{l}6,710,000 \\
89 \\
2,630\end{array}$ & $\begin{array}{l}20,000 \\
15 \\
4 \mathrm{mrem} / \mathrm{yr}^{\mathrm{a}}\end{array}$ & $\begin{array}{l}3,690,000 \\
103 \\
2840\end{array}$ & Fourmile Branch \\
\hline R-Area & Tritium & $\mathrm{pCi} / \mathrm{L}$ & 111,000 & 20,000 & 41,900 & $\begin{array}{l}\text { Mill Creek in } \\
\text { Northwest; } \\
\text { tributaries of } \\
\text { PAR Pond } \\
\text { elsewhere }\end{array}$ \\
\hline K-Area & $\begin{array}{l}\text { Tritium } \\
\text { TCE }^{b}\end{array}$ & $\begin{array}{l}\mathrm{pCi} / \mathrm{L} \\
\mathrm{ppb}\end{array}$ & $\begin{array}{l}26,900,000 \\
17\end{array}$ & $\begin{array}{l}20,000 \\
5\end{array}$ & $\begin{array}{l}615,000 \\
15.9\end{array}$ & $\begin{array}{l}\text { Indian Graves } \\
\text { Branch }\end{array}$ \\
\hline L-Area & Tritium & $\mathrm{pCi} / \mathrm{L}$ & $1,250,000$ & 20,000 & $1,250,000$ & L Lake \\
\hline P-Area & $\begin{array}{l}\text { Tritium }^{\mathrm{b}} \\
\text { TCE }\end{array}$ & $\begin{array}{l}\mathrm{pCi} / \mathrm{L} \\
\mathrm{ppb}\end{array}$ & $\begin{array}{l}18,400,000 \\
13,600\end{array}$ & $\begin{array}{l}20,000 \\
5\end{array}$ & $\begin{array}{l}1,950,000 \\
14,448\end{array}$ & $\begin{array}{l}\text { Steel Creek in } \\
\text { North; Meyer's } \\
\text { Branch in South }\end{array}$ \\
\hline $\begin{array}{l}\text { Sanitary } \\
\text { Landfill }\end{array}$ & $\begin{array}{l}\text { TCE } \\
\text { Vinyl Chloride }\end{array}$ & $\begin{array}{l}\text { Ppb } \\
\text { ppb }\end{array}$ & $\begin{array}{l}16 \\
30\end{array}$ & $\begin{array}{l}5 \\
2\end{array}$ & $\begin{array}{l}17 \\
121\end{array}$ & $\begin{array}{l}\text { Upper Three } \\
\text { Runs Creek }\end{array}$ \\
\hline TNX & TCE & $\mathrm{ppb}$ & 566 & 5 & 520 & $\begin{array}{l}\text { Savannah River } \\
\text { Swamp }\end{array}$ \\
\hline CMP Pits & TCE & $\mathrm{ppb}$ & 1.090 & 5 & 1300 & Pen Branch \\
\hline
\end{tabular}

${ }^{a} \mathrm{MCL}=$ Maximum contaminant level

${ }^{b}$ The activity ( $\left.\mathrm{pCi} / \mathrm{L}\right)$ equivalent to $4 \mathrm{mrem} / \mathrm{yr}$ varies according to which specific beta emitters are present in the sample. 



\title{
Quality Assurance
}

\author{
Jay Hutchison \\ Environmental and Bioassay Laboratory \\ Donald Padgett and Monte Steedley \\ Environmental Services Section \\ Rick Page and Mike Boerste \\ Geochemical Monitoring Group
}

[Editor's note: During 2006, responsibility for the environmental Quality Assurance (QA) program was divided among three groups - the Environmental Monitoring Laboratory (EML), the Environmental Permitting and Monitoring group (EPM), and the Geochemical Monitoring and Data Management and Waste Engineering group (GM\&DMWE)].

RRS's environmental QA program is conducted to verify the integrity of data generated by onsite and subcontracted offsite environmental laboratories.

The program's objectives are to ensure that samples are representative of the surrounding environment, and that analytical results are accurate.

\section{QA for EPM Program Samples}

\section{Internal Quality Assurance Program}

EPM has a documented QA program that meets SRS and U.S. Department of Energy (DOE) requirements. Based on periodic inspections, no significant QA issues or corrective actions were identified during 2006.

\section{Laboratory Certification}

EPM is certified by the South Carolina Department of Health and Environmental Control (SCDHEC) Office of Laboratory Certification for field $\mathrm{pH}$ and total residual chlorine measurements.

\section{Blind pH Samples}

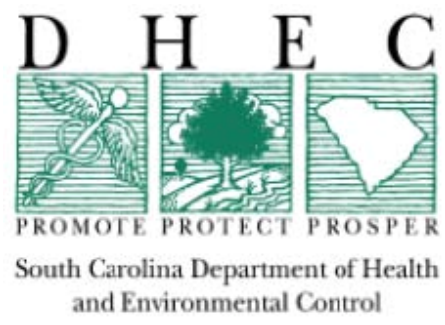

EPM personnel routinely conduct a blind sample program for field measurements of $\mathrm{pH}$ to assess the quality and reliability of field data measurements. 


\section{Quality Control Sample Definitions}

Blank - A sample that has not been exposed to the analyzed sample stream in order to monitor contamination during sampling, transport, storage, or analysis. The blank is subjected to the usual analytical and measurement process to establish a zero-baseline or -background value, and sometimes is used to adjust or correct routine analytical results.

Instrument Blank - A clean sample (e.g., distilled water) processed through the instrumental steps of the measurement process; used to determine instrument contamination.

Method Blank - A matrix sample - similar to the batch of associated samples (when available) - that is free from the analytes of interest and is processed simultaneously with-and under the same conditions as-samples through all steps of the analytical procedures, and in which no target analytes or interferences are present at concentrations that impact the analytical results for sample analyses.

Reagent Blank - A sample containing reagent(s), without the target analyte or sample matrix, that is introduced into the analytical procedure at the appropriate point-and that is carried through all subsequent steps to determine the contribution of the reagents and of the involved analytical steps.

Blind Sample - A subsample for analysis with a composition known to the submitter. The analyst/laboratory may know the identity of the sample, but not its composition. It is used to test the analyst's or laboratory's proficiency in the execution of the measurement process.

Carrier - A stable isotope of a radionuclide (usually the analyte) added to increase the total amount of that element so that a measurable mass of the element is present.

Laboratory Control Sample (LCS) - A sample matrix, free from the analytes of interest, spiked with verified known amounts of analytes or a material containing known and verified amounts of analytes. It generally is used to establish intralaboratory or analyst-specific precision and bias, or to assess the performance of all or a portion of the measurement system.

Laboratory Duplicate - Aliquot of a sample taken from the same container under laboratory conditions and processed and analyzed independently.

Spike - A known mass of target analyte added to a blank sample or subsample; used to determine recovery efficiency, or for other QC purposes.

Tracer - A radioactive isotope that chemically mimics and does not interfere with the target analyte through radiochemical separations. Isotopic tracers typically are radioactive materials (e.g., U-232, Pu242). Tracers are added to samples to determine the overall chemical yield for the analytical preparation steps.

During 2006, blind $\mathrm{pH}$ field measurements were taken for 24 samples. All field $\mathrm{pH}$ measurements were within the U.S. Environmental Protection Agency's (EPA's) suggested acceptable control limit of $\pm 0.4 \mathrm{pH}$ units of the true (known) value.

\section{QA for EML Sample Analyses}

\section{Internal QA Program}

EML has a documented QA program that meets SRS and DOE requirements. Instruments are calibrated with known reference standards. Instrument performance is monitored through the use of checks and control charts. Analytical batch performance is measured through the use of quality control (QC) samples (blanks, spikes, carriers, tracers, laboratory control samples, and duplicates). QC results that fall outside of specified limits may result in analytical batch or sample reruns. If a batch or sample is not rerun, the reason is documented in the data package, which includes the QA cover sheet, instrument data printouts, and associated QC data. 
Based on periodic inspections of instrument records and analytical data packages, no significant quality assurance issues or corrective actions were identified during 2006.

\section{Laboratory Certification}

EML is certified by the SCDHEC Office of Laboratory Certification for the measurement of following analytes:

- total suspended solids and 27 metals (under the Clean Water Act)

- 42 volatile organic compounds (VOCs) and 28 metals (under the Resource Conservation and Recovery Act)

\section{Blind Tritium Samples}

Blind tritium samples provide an assessment of laboratory sample preparation and counting. During 2006, eight blind samples were analyzed for tritium; all of the results were within control limits. Complete results (including control limits) can be found in the "Blind Sample Results for Tritium" table on the CD accompanying this report.

\section{External QA Program}

In 2006, EML participated in the DOE Mixed Analyte Performance Evaluation Program (MAPEP), an interlaboratory comparison program that tracks performance accuracy and tests the quality of environmental data reported to DOE. The Radiological and Environmental Sciences Laboratory (RESL), under the direction of DOE-Headquarters Environmental Safety and Health $(\mathrm{ES} \& \mathrm{H})$, administers the MAPEP.

MAPEP samples include water, soil, air filter, and vegetation matrices with environmentally important stable inorganic, organic, and radioactive constituents.

In 2006, EML completed the analysis of 56 radioisotopes and 15 metals for MAPEP-15 (designation of a specific study set), and of 52 radioisotopes and 15 metals for MAPEP-16. The results show that the laboratory exceeded the expected 80-percent-acceptable-results level for each study set (table 8-1). The rating was calculated by dividing the acceptable and the acceptable-with-warning results by the total number of results.

MAPEP intercomparison study results for EML can be found in the data tables section of the CD accompanying this report.

\section{QA for EPM Sample Analyses}

Onsite and subcontract environmental laboratories providing analytical services must have documented QA programs and meet the quality requirements defined in the WSRC Quality Assurance Manual (WSRC 1Q).

An annual DOE Consolidated Audit Program (DOECAP) evaluation of each subcontract laboratory is performed to ensure that all the laboratories maintain technical competence and follow the required QA programs. Each evaluation includes an examination of 
Table 8-1

EML Performance on Mixed Analyte Performance Evaluation Program (MAPEP)

\begin{tabular}{lll}
\hline Study Set & Matrix & EML $^{\text {a }}$ \\
\hline MAPEP-06-GrF15 & Air Filter & $100 \%$ \\
MAPEP-06-GrW15 & Water & $100 \%$ \\
MAPEP-06-MaS15 & Solid & $100 \%$ \\
MAPEP-06-MaW15 & Water & $100 \%$ \\
MAPEP-06-RdF15 & Air Filter & $100 \%$ \\
MAPEP-06-MaV15 & Vegetation & $100 \%$ \\
MAPEP-06-GrF16 & Air Filter & $100 \%$ \\
MAPEP-06-GrW16 & Water & $100 \%$ \\
MAPEP-06-MaS16 & Solid & $92 \%{ }^{\mathrm{b}}$ \\
MAPEP-06-MaW16 & Water & $100 \%$ \\
MAPEP-06-RdF16 & Air Filter & $100 \%$ \\
MAPEP-06-MaV16 & Vegetation & $100 \%$ \\
\hline a Column presents the percentage of tests that exceeded the 80\%-acceptable-results level. \\
besults for Cs-134 were acceptable with warning (bias between 20\% and 30\%). \\
\hline
\end{tabular}

laboratory performance with regard to sample receipt, instrument calibration, analytical procedures, data verification, data reports, records management, nonconformance and corrective actions, and preventive maintenance. Reports of the findings and recommendations are provided to each laboratory, and follow-up evaluations are conducted as necessary. No DOECAP evaluation was conducted for onsite laboratories.

\section{Nonradiological Liquid Effluents}

National Pollutant Discharge Elimination System (NPDES) samples are analyzed by four onsite laboratories groups-EML, EPM, the Site Infrastructure \& Services Department (I\&SD), and Westinghouse Safety Management Solutions (WSMS) - and one offsite subcontract laboratory, Shealy Environmental Services (SES). All these laboratories must be certified by SCDHEC for NPDES analyses.

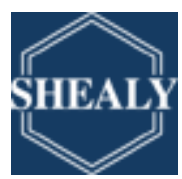

\section{Interlaboratory Program}

During 2006, all laboratories performing NPDES analyses for WSRC participated in the Environmental Resource Associates (ERA) Water Pollution (WP) performance evaluation studies for compliance with the EPA-required Discharge Monitoring Report-QA Study 26. ERA, as required by EPA, is accredited by the American Association of Laboratory Accreditation and the National Institute of Standards and Technology. 
EPA and SCDHEC use the study results to certify laboratories for specific analyses. As part of the recertification process, these agencies require that laboratories investigate the unacceptable results and implement corrective actions as appropriate.

WSMS participated in the 2006 DMR-QA Study 26, while SES, EPM, EML, and I\&SD participated in ERA's WP-137 and WP-138 studies.

With the exception of one parameter, all results were acceptable. The offsite laboratory received a "not acceptable" result for oil and grease in the WP-137 study. The cause of the failure was determined, and an acceptable result was obtained in the WP-138 study.

\section{Intralaboratory Program}

The environmental monitoring intralaboratory program reviews laboratory performance by analyzing duplicate and blind samples throughout the year.

The onsite and offsite laboratories processed 89 duplicate analyses during 2006. Zero-difference results were reported for 45 of these analyses. Eight of the 89 duplicate analyses exceeded the relative-percent difference ( \pm 20 -percent difference).

The onsite and offsite laboratories processed 74 blind analyses during 2006. Zero-difference results were reported for 45 of these analyses. Seven of the 74 blind analyses exceeded the relative percent difference ( \pm 20 -percent difference). Results for the duplicate and blind sampling programs showed no indications of consistent problems in the laboratories.

\section{Stream and River Water Quality}

SRS's water quality program requires checks of 10 percent of the samples to verify analytical results. Duplicate grab samples from SRS streams and the Savannah River were analyzed by SES and EML in 2006. SES and EML reported 564 analyses for this program. Most results were within acceptance limits (+20-percent difference). Approximately 10 percent of the 277 duplicate results evaluated fell outside the acceptance limits. Results for the duplicate sampling program showed no indications of consistent problems with the laboratories. Detailed stream and Savannah River duplicate sample results can be found in the data tables section of the CD accompanying this report.

\section{QA for SGCP Sample Analyses}

Groundwater analyses at SRS are performed by subcontract and onsite laboratories. During 2006, General Engineering and Severn Trent were the primary full-service subcontractors; Eberline Services Oak Ridge Lab (radiological only) and Lionville (nonradiological only) were used to a lesser extent; and MicroSeeps, Inc., performed special analyses. In addition to the subcontract laboratories, EML performed groundwater analyses on site.

During 2006, General Engineering Laboratories, Severn Trent Laboratories, Inc., and Lionville Laboratory, Inc., participated in various WP and WS studies. These laboratories are required by contract to participate in the WP and WS studies. The results for WP-130 through WP-141 and WS-114 through WS-123 (table 8-2) show that the laboratories met or exceeded the 80-percentacceptable-results level. The table reflects only the studies in which the laboratories actually participated. 


\begin{tabular}{|c|c|c|c|c|c|c|}
\hline \multicolumn{7}{|c|}{$\begin{array}{l}\text { Subcontract-Laboratory Performance Environmental Resource Associates (ERA) } \\
\text { Water Pollution Studies }\end{array}$} \\
\hline \multirow[t]{2}{*}{ Study } & \multicolumn{2}{|c|}{ General Engineering } & \multicolumn{2}{|c|}{ Severn Trent } & \multicolumn{2}{|c|}{ Lionville } \\
\hline & Acceptable & Fail & Acceptable & Fail & Acceptable & Fail \\
\hline WP-130 & $100 \%$ & & & & & \\
\hline WP-132 & & & $95 \%$ & $5 \%$ & $96 \%$ & $4 \%$ \\
\hline WP-135 & $99 \%$ & $1 \%$ & & & & \\
\hline WP-138 & $98 \%$ & $2 \%$ & $99 \%$ & $1 \%$ & $98 \%$ & $2 \%$ \\
\hline WP-139 & $100 \%$ & & & & & \\
\hline WP-140 & $100 \%$ & & & & & \\
\hline WP-141 & $100 \%$ & & & & & \\
\hline WS-114 & $94 \%$ & $6 \%$ & & & & \\
\hline WS-117 & $86 \%$ & $14 \%$ & $100 \%$ & & & \\
\hline WS-120 & $92 \%$ & $8 \%$ & & & & \\
\hline WS-121 & $100 \%$ & & & & & \\
\hline WS-122 & $80 \%$ & $20 \%$ & & & & \\
\hline WS-123 & $100 \%$ & & $92 \%$ & $8 \%$ & & \\
\hline
\end{tabular}

Results from the laboratories are summarized in table 8-3. The results show that all but one laboratory exceeded the expected 80-percent-acceptable-results level for all studies for both the soil and groundwater matrices. Following receipt of the results, samples have not been sent to the laboratory that did not meet the expected 80-percent-acceptable-results level. Samples will not be sent to this laboratory until it provides a corrective action response. The air filter and vegetation matrices are not included in the subcontract laboratory performance summary because these matrices are not part of the SGCP program.

\section{Soil/Sediment}

Environmental investigations of soils and sediments, primarily for RCRA/CERCLA units, are performed by subcontract laboratories. Data are validated by SGCP according to EPA standards for analytical data quality, or as specified by SRS customers.

The environmental validation program is based in part on two EPA guidance documents, "Guidance for the Data Quality Objectives Process for Superfund" (EPA-540-R-93-071) and "Data Quality Objectives Process for Waste Site Investigations" (QA/G-4HW) (EPA-600/R-00007). These documents identify QA issues to be addressed, but they do not formulate a procedure for data evaluation or provide pass/fail criteria to apply to data and document acceptance. Hence, the validation program contains elements from - and is influenced by - several other references, including 
Table 8-3

Subcontract-Laboratory Performance on Mixed-Analyte Performance Evaluation Program (MAPEP)

\begin{tabular}{|c|c|c|c|c|c|c|}
\hline 흘 & 竞 & 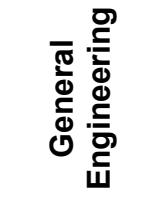 & 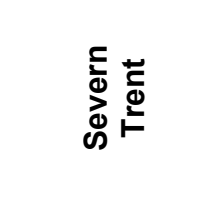 & 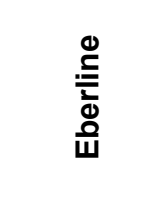 & 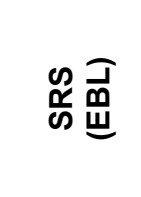 & 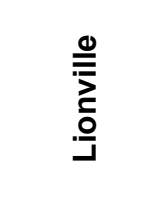 \\
\hline MAPEP-06-MaS15 & Water & ${ }_{d} 8 \% \%^{1,15, a}$ & $\begin{array}{l}89 \%^{1,2,4,6,8,9} \\
10,14,16,17,18\end{array}$ & $100 \%$ & $100 \%$ * & $99 \%^{\dagger}$ \\
\hline MAPEP-06-MaW15 & Water & $97 \%^{3}$ & $100 \%$ & $100 \%$ * & $100 \%$ & $\begin{array}{l}87 \% \%^{(10)} \\
13,14 \dagger\end{array}$ \\
\hline MAPEP-06-OrW15 & Water & $100 \%$ & $97 \%{ }^{(19),(20)}$ & No Data & No Data & $100 \%$ \\
\hline MAPEP-06-GrW15 & Solid & $100 \%$ & $100 \%$ & $50 \%{ }^{12}$ & $100 \%$ & No Data \\
\hline MAPEP-06-MaS16 & Water & $\underset{b, c}{99} \%^{(7)}$ & $97 \%{ }^{2,(7), 8}$ & $94 \%^{5 *}$ & $100 \% *$ & $\begin{array}{l}94 \% 3,(7), 9 \\
(10),(11) \dagger\end{array}$ \\
\hline MAPEP-06-MaW16 & Water & $100 \%$ & $100 \%$ & $100 \%$ * & $100 \%$ & $100 \%$ \\
\hline MAPEP-06-OrW16 & Water & $100 \%$ & $100 \%$ & No Data & No Data & $100 \%$ \\
\hline MAPEP-06-GrW16 & Solid & $100 \%$ & $100 \%$ & $100 \%$ & $100 \%$ & No Data \\
\hline \multicolumn{3}{|c|}{$\begin{array}{l}{ }_{2}^{1} \text { Results for strontium-90 were not acceptable. } \\
2 \text { Results for antimony were not acceptable. } \\
{ }^{3} \text { Results for iron-55 were not acceptable. } \\
{ }^{4} \text { Results for chromium were not acceptable. } \\
{ }^{5} \text { Results for nickel-63 were not acceptable. } \\
{ }^{6} \text { Results for uranium-238 were not acceptable. } \\
{ }_{7}^{7} \text { Results for endosulfan II were not acceptable. } \\
{ }^{8} \text { Results for zinc were not acceptable. } \\
{ }_{9}^{9} \text { Results for uranium (total) were not acceptable } \\
10 \text { Results for beta (BHC) were not acceptable. } \\
{ }_{11} \text { Results for methoxychlor were not acceptable. } \\
{ }_{12} \text { Results for gross beta were not acceptable. } \\
13 \text { Results for cadmium were not acceptable. } \\
{ }_{14} \text { Results for copper were not acceptable. } \\
15 \text { Results for cesium-134 were not acceptable. } \\
{ }_{16} \text { Results for beryllium were not acceptable. } \\
{ }^{17} \text { Results for nickel were not acceptable. }\end{array}$} & $\begin{array}{l}{ }^{a} \text { Results for ni } \\
{ }^{b} \text { Results for ar } \\
\text { warning. } \\
{ }^{c} \text { Results for ur } \\
\text { warning. } \\
{ }^{d} \text { Results for ur } \\
\text { warning. }\end{array}$ & $\begin{array}{l}\text {-63 were a } \\
\text { icium- } 241 \text { um (total) w } \\
\text { um-235 we }\end{array}$ & $\begin{array}{l}\text { ptable with } \\
\text { acceptable } \\
\text { acceptable } \\
\text { cceptable v } \\
\text { rted } \\
\text { poorted }\end{array}$ & $\begin{array}{l}\text { re not } \\
\text { arning. } \\
\text { vith } \\
\text { ith }\end{array}$ \\
\hline
\end{tabular}

- "Guidance on Environmental Data Verification and Data Validation" (QA/G-8), EPA-240/R-02/004

- "USEPA Contract Laboratory Program National Functional Guidelines for Organic Data Review," EPA-540/R-99/008

- "USEPA Contract Laboratory Program National Functional Guidelines for Chlorinated Dioxin/Furan Data Review," EPA-540/R-05/001

- "USEPA Contract Laboratory Program National Functional Guidelines for Inorganic Data Review," EPA-540/R-04/004 
- “Test Methods for Evaluating Solid Waste," EPA, November 1986, SW-846, Third Edition; Latest Update, July 2005

- “DOE Quality Systems for Analytical Services,” Revision 2.2, October 2006

Many QA parameters are evaluated by automated processing of electronically reported data. Others are selectively evaluated by manual inspection of associated analytical records. A summary of findings is presented in each project narrative or validation report prepared by SGCP personnel.

\section{Data Review}

The QA program's detailed data review for groundwater and soil/sediment analyses is described in WSRC-3Q1-2, Section 1100.

In 2006, the major QA issues discovered and addressed in connection with these programs for soil/sediment and groundwater analyses included the following:

- Inadequate internal standardization for total uranium by ICP-MS at one laboratory

- Outdated interelement corrections for ICP-AES metals at two laboratories

- Calibrated region deviations for alpha spectroscopy analytes at one laboratory

- Calibration spreadsheet errors for strontium-90 and gross alpha/beta at one laboratory

- Calibration stability problems for isobutanol at one laboratory

- Uncertain identification for total dioxins due to combined standards and co-elution

- Liquid scintillation counting without standard quench correction at one laboratory

Previously identified items resolved in 2006 included the following:

- Cyanide analysis without primary distillation checking at one laboratory

- Nitrate-nitrite analysis without reduction checks at one laboratory

Previously identified items still being addressed include the following:

- Gas-flow proportional counting without complete cross-talk calibration at two laboratories (This issue is being resolved through a formal DOE resolution process.)

- Incomplete record packages for validation (ongoing)

- Omissions and logic failures in electronically reported data (ongoing)

These findings illustrate that, although laboratory procedures are well defined, analytical data quality does benefit from technical scrutiny. A corrective action plan has been put into place to address these issues, which are expected to be resolved during 2007. 


\section{Applicable Guidelines, Standards, and Regulations}

Jack Mayer

Environmental Services Section

$\mathrm{T}$

THE Savannah River Site (SRS) environmental monitoring program is designed to meet state and federal regulatory requirements for radiological and nonradiological programs. These requirements are stated in U.S. Department of Energy (DOE)

Order 5400.5, "Radiation Protection of the Public and the Environment"; in the Clean Air Act [Standards of Performance for New Stationary Sources, also referred to as New Source Performance Standards, and the National Emission Standards for Hazardous Air Pollutants (NESHAP)]; in the Comprehensive Environmental Response, Compensation, and Liability Act (CERCLA - also known as Superfund); in the Resource Conservation and Recovery Act (RCRA); in the Clean Water Act (i.e., National Pollutant Discharge Elimination System-NPDES); and in the National Environmental Policy Act (NEPA). Compliance with environmental requirements is assessed by DOE-Savannah River Operations Office (DOE-SR), the South Carolina Department of Health and Environmental Control (SCDHEC), and the U.S. Environmental Protection Agency (EPA).

The SRS environmental monitoring program's objectives incorporate recommendations of

- the International Commission on Radiological Protection (ICRP) in Principles of Monitoring for the Radiation Protection of the Public, ICRP Publication 43

- DOE Order 5400.5

- DOE/EH-0173T, "Environmental Regulatory Guide for Radiological Effluent Monitoring and Environmental Surveillance"

Detailed information about the site's environmental monitoring program is documented in Section 1100 (SRS Environmental Monitoring Program) of the SRS Environmental Monitoring Section Plans and Procedures, WSRC-3Q1-2, Volume 1. This document is reviewed annually and updated every 3 years.

SRS has implemented and adheres to the SRS Environmental Management System (EMS) Policy. Implementation of a formal EMS, such as that described in the International Organization for Standardization (ISO) 14001 standard, is an Executive Order 13148

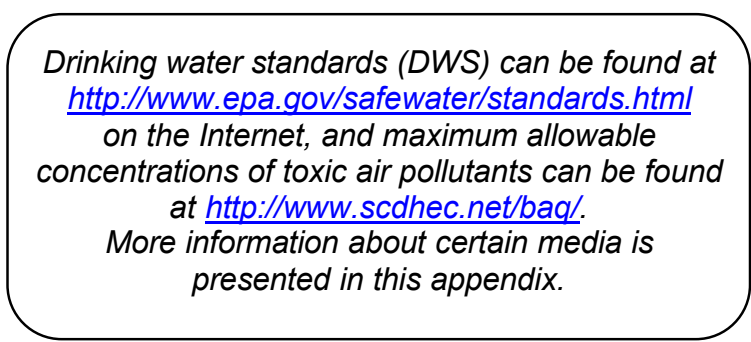

("Greening the Government Through

Leadership in Environmental Management") and DOE Order 450.1 ("Environmental Protection Program") requirement. SRS maintains an EMS that fully meets the requirements of ISO 14001. The full text of the SRS EMS Policy appears in chapter 2. 


\section{Air Effluent Discharges}

DOE Order 5400.5 establishes Derived Concentration Guides (DCGs) for radionuclides in air. DCGs, calculated by DOE using methodologies consistent with recommendations found in ICRP publications 26 (Recommendations of the International Commission on Radiological Protection) and 30 (Limits for Intakes of Radionuclides by Workers), are used as reference concentrations for conducting environmental protection programs at DOE sites. DCGs are not considered release limits. DCGs for radionuclides in air are discussed in more detail on page 116 .

Radiological airborne releases also are subject to EPA regulations cited in 40 CFR 61, "National Emission Standards for Hazardous Air Pollutants," Subpart H ("National Emission Standards for Emissions of Radionuclides Other Than Radon from Department of Energy Facilities").

Regulation of radioactive and nonradioactive air emissions - both criteria pollutants and toxic air pollutants - has been delegated to SCDHEC. Therefore, SCDHEC must ensure that its air pollution regulations are at least as stringent as federal regulations required by the Clean Air Act. This is accomplished by SCDHEC Regulation 61-62, "Air Pollution Control Regulations and Standards." As with many regulations found in the Code of Federal Regulations (CFR), many of SCDHEC's regulations and standards are source specific. Each source of air pollution at SRS is permitted or exempted by SCDHEC, with specific emission rate limitations or special conditions identified. The bases for the limitations and conditions are the applicable South Carolina air pollution control regulations and standards. In some cases, specific applicable CFRs also are cited in the permits issued by SCDHEC. The applicable SCDHEC regulations are too numerous to discuss here, so only the most significant are listed.

Two SCDHEC standards, which govern criteria and toxic air pollutants and ambient air quality, are applicable to all SRS sources. Regulation 61-62.5, Standard No. 2, "Ambient Air Quality Standards," identifies eight criteria air pollutants commonly used as indices of air quality (e.g., sulfur dioxide, nitrogen dioxide, and lead) and provides allowable site boundary concentrations for each pollutant, as well as the measuring intervals. Compliance with the various pollutant standards is determined by conducting air dispersion modeling for all sources of each pollutant, using EPA-approved dispersion models and then comparing the results to the standard. The pollutants, measuring

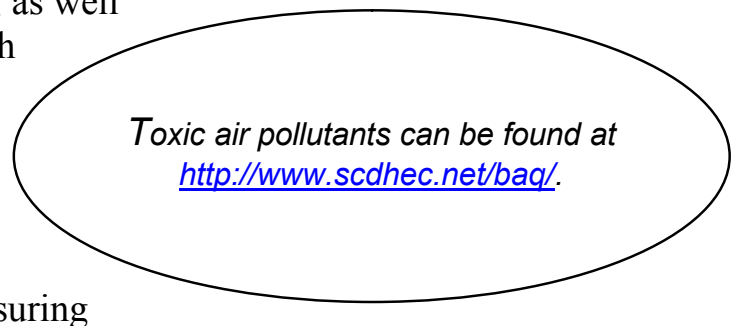
intervals, and allowable concentrations are provided in table A-1. The standards are in micrograms per cubic meter, unless noted otherwise.

A total of 258 toxic air pollutants and their respective allowable site boundary concentrations are identified in Regulation 61-62.5, Standard No. 8, "Toxic Air Pollutants." As with Standard No. 2, compliance is determined by air dispersion modeling.

SCDHEC airborne emission standards for each SRS permitted source may differ, based on size and type of facility, type and amount of expected emissions, and the year the facility was placed into operation. For example, SRS powerhouse coal-fired boilers are regulated 
Table A-1

Criteria Air Pollutants

\begin{tabular}{|c|c|c|}
\hline Pollutant & Interval & Unit $^{a, b}$ \\
\hline \multirow[t]{3}{*}{ Sulfur Dioxide } & 3 hours & $1,300 \mu \mathrm{g} / \mathrm{m}^{3 \mathrm{c}}$ \\
\hline & 24 hours & $365 \mu \mathrm{g} / \mathrm{m}^{3 \mathrm{c}}$ \\
\hline & annual & $80 \mu \mathrm{g} / \mathrm{m}^{3}$ \\
\hline Total Suspended Particulates & annual geometric mean & $75 \mu \mathrm{g} / \mathrm{m} 3$ \\
\hline \multirow[t]{2}{*}{$\mathrm{PM}_{10}$} & 24 hours & $150 \mu \mathrm{g} / \mathrm{m}^{3 \mathrm{~d}}$ \\
\hline & annual & $50 \mu g / m^{3 d}$ \\
\hline \multirow[t]{2}{*}{$\mathrm{PM}_{2.5}$ (Primary and Secondary Standards) } & 24 hours & $65 \mu \mathrm{g} / \mathrm{m}^{3 \mathrm{~d}}$ \\
\hline & annual & $15 \mu \mathrm{g} / \mathrm{m}^{3 \mathrm{~d}}$ \\
\hline \multirow[t]{2}{*}{ Carbon Monoxide } & 1 hour & $40 \mathrm{mg} / \mathrm{m}^{3}$ \\
\hline & 8 hours & $10 \mathrm{mg} / \mathrm{m}^{3}$ \\
\hline Ozone & 8 hours & $0.08 p^{p} m^{d}$ \\
\hline \multirow[t]{4}{*}{ Gaseous Fluorides (as HF) } & 12-hour average & $3.7 \mu \mathrm{g} / \mathrm{m}^{3}$ \\
\hline & 24-hour average & $2.9 \mu \mathrm{g} / \mathrm{m}^{3}$ \\
\hline & 1-week average & $1.6 \mu \mathrm{g} / \mathrm{m}^{3}$ \\
\hline & 1-month average & $0.8 \mu \mathrm{g} / \mathrm{m}^{3}$ \\
\hline Nitrogen Dioxide & annual & $100 \mu \mathrm{g} / \mathrm{m}^{3}$ \\
\hline Lead & calendar quarterly mean & $1.5 \mu \mathrm{g} / \mathrm{m}^{3}$ \\
\hline \multicolumn{3}{|c|}{${ }^{a}$ Arithmetic average except in case of total suspended particulate matter } \\
\hline \multicolumn{3}{|c|}{${ }^{\mathrm{C}}$ Not to be exceeded more than once a year } \\
\hline \multicolumn{3}{|c|}{$\begin{array}{l}{ }^{\mathrm{d}} \text { Attainment determinations will be made based on the criteria contained in } 40 \mathrm{CFR} 50 \text {, appendices } \mathrm{H}, \mathrm{I}, \mathrm{K} \text {, } \\
\text { and } \mathrm{N} \text {. }\end{array}$} \\
\hline
\end{tabular}

by Regulation 61-62.5, Standard No. 1, "Emissions from Fuel Burning Operations." This standard specifies that for powerhouse stacks built before February 11, 1971, the opacity limit is 40 percent. For new sources constructed after this date, the opacity limit typically is 20 percent. The standards for particulate and sulfur dioxide emissions are shown in table A-2.

Regulation 61-62.5, Standard No. 4, "Emissions from Process Industries," is applicable to all SRS sources except those regulated by a different source-specific standard. For some SRS sources, particulate matter emission limits depend on the weight of the material being processed and are determined from a table in the regulation. For process and diesel engine stacks in existence on or before December 31, 1985, emissions shall not exhibit an opacity 


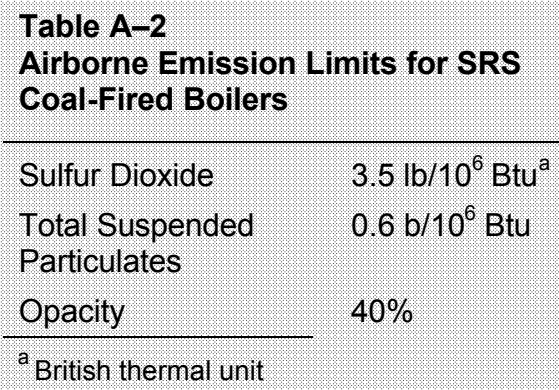

Table A-3

Airborne Emission Limits for SRS Fuel Oil-Fired Package Boilers

Sulfur Dioxide

Total Suspended : $0.6 \mathrm{~b} / 10^{6} \mathrm{Btu}$ Particulates

Opacity $20 \%$

${ }^{a}$ British thermal unit

greater than 40 percent. For new sources, where construction began after December 31, 1985 , the opacity limit is 20 percent.

As previously mentioned, some SRS sources have both SCDHEC and CFRs applicable and identified in their permits. For the package steam generating boilers in K-Area and two portable package boilers, both SCDHEC and federal regulations are applicable. The standard for sulfur dioxide emissions is specified in 40 CFR 60, Subpart Dc, "Standards of Performance for Small Industrial-Commercial-Institutional Steam Generating Units," while the standard for particulate matter is found in Regulation 61-62.5, Standard No. 1.

Because these units were constructed after applicability dates found in both regulations, the opacity limit for the units is the same in both regulations. The emissions standards for these boilers are presented in table A-3.

\section{(Process) Liquid Effluent Discharges}

DOE Order 5400.5 establishes DCGs for radionuclides in process effluents. (DCGs for radionuclides in liquid are discussed in more detail on page 75.) DCGs were calculated by DOE using methodologies consistent with recommendations found in ICRP, 1987, and ICRP, 1979, and are used

- as reference concentrations for conducting environmental protection programs at DOE sites

- as screening values for considering best available technology for treatment of liquid effluents

DOE Order 5400.5 exempts aqueous tritium releases from best available technology requirements but not from ALARA (as low as reasonably achievable) considerations.

Three NPDES permits are in place that allow SRS to discharge water into site streams and the Savannah River: one industrial wastewater permit (SC0000175) and two stormwater runoff permits (SCR000000 for industrial discharges and SCR100000 for construction discharges).

A fourth permit (ND0072125) is a no-discharge water- pollution-control land application permit that regulates sludge generated at onsite sanitary waste treatment plants. 
Detailed requirements for each permitted discharge point—including parameters sampled for, permit limits for each parameter, sampling frequency, and method for collecting each sample - can be found in the individual permits, which are available to the public through SCDHEC's Freedom of Information Office at 803-898-3882.

\section{Site Streams}

SRS streams are classified as "Freshwaters" by South Carolina Regulation 61-69, "Classified Waters." Freshwaters are defined in Regulation 61-68, "Water Classifications and Standards," as surface water suitable for

- primary- and secondary-contact recreation and as a drinking water source after conventional treatment in accordance with SCDHEC requirements

- fishing and the survival and propagation of a balanced indigenous aquatic community of fauna and flora

- industrial and agricultural uses

Table A -4 provides some of the specific South Carolina freshwater standards used in water quality surveillance, but because some of these standards are not quantifiable, they are not tracked in response form (i.e., amount of garbage found).

\section{Savannah River}

Because the Savannah River is defined under South Carolina Regulation 61-69 as a freshwater system, the river is regulated in the same manner as site streams (table A-4).

\section{Drinking Water}

The federal Safe Drinking Water Act — enacted in 1974 to protect public drinking water supplies_-was amended in 1977, 1979, 1980, 1986, and 1996.

SRS drinking water systems are tested routinely by SRS and SCDHEC to ensure compliance with SCDHEC State Primary Drinking Water Regulations (R61-58) and EPA National Primary Drinking Water Regulations (40 CFR 141).

SRS drinking water is supplied by 17 separate systems, all of which utilize groundwater sources. The A-Area, D-Area, and K-Area systems are actively regulated by SCDHEC, while the remaining 14 site water systems receive a reduced level of regulatory oversight.

D-Area and K-Area were sampled in 2006 for lead and copper, and neither system exceeded the lead and copper action levels. The A-Area system will be resampled for lead and copper in 2007.

DWS for specific radionuclides and contaminants can be found on the Internet at http://www.epa.gov/safewater/standards.html.
Although the B-Area Bottled Water Facility is not listed by SCDHEC as a public water system, SCDHEC's Division of Food Protection will continue to conduct periodic inspections of this facility. Results 
Table A-4

South Carolina Water Quality Standards for Freshwaters ${ }^{a}$

\begin{tabular}{ll}
\hline Parameters & Standards \\
\hline Fecal coliform & Not to exceed a geometric mean of $200 / 100 \mathrm{~mL}$, \\
& based on five consecutive samples during any \\
& 30-day period; nor shall more than 10 percent of \\
the total samples during any 30 -day period & exceed $400 / 100 \mathrm{~mL}$
\end{tabular}

$\mathrm{pH}$

Temperature

Dissolved oxygen

Garbage, cinders, ashes, sludge, or other refuse

Treated wastes, toxic wastes, deleterious substances, colored or other wastes, except in the parameter immediately above

Toxic pollutants listed in South Carolina Regulation 61-68, "Water Classifications and Standards"

\section{Range between 6.0 and 8.5}

Generally, shall not be increased more than $5^{\circ} \mathrm{F}$ $\left(2.8^{\circ} \mathrm{C}\right)$ above natural temperature conditions or be permitted to exceed a maximum of $90^{\circ} \mathrm{F}$ $\left(32.2^{\circ} \mathrm{C}\right)$ as a result of the discharge of heated liquids; for more details, see E.12, Regulation 61-68, "Water Classifications and Standards" (June 25, 2004)

Daily average not less than $5.0 \mathrm{mg} / \mathrm{L}$, with a low of $4.0 \mathrm{mg} / \mathrm{L}$

None allowed

None alone or in combination with other substances of wastes in sufficient amounts to make the waters unsafe or unsuitable for primary-contact recreation or to impair the waters for any other best usage as determined for the specific waters assigned to this class

See Appendix: Water Quality Numeric Criteria for the Protection of Aquatic Life and Human Health, Regulation 61-68, "Water Classifications and Standards" (June 25, 2004)

\footnotetext{
${ }^{\mathrm{a}}$ This is a partial list of water quality standards for freshwaters.
}

from quarterly bacteriological and annual complete chemical analyses performed in 2006 met SCDHEC and FDA water quality standards.

\section{Groundwater}

Groundwater is a valuable resource and is the subject of both protection and cleanup programs at SRS. More than 1,000 wells are monitored each year at the site for a wide range of constituents. Monitoring in the groundwater protection program is performed to detect new or unknown contamination across the site, and monitoring in the groundwater cleanup program is performed to meet the requirements of state and federal laws and regulations. Most of the monitoring in the cleanup program is governed by SCDHEC's administration of RCRA regulations.

The analytical results of samples taken from SRS monitoring wells are compared to various standards. The most common are final federal primary DWS — or other standards if DWS do not exist. The DWS are considered first because groundwater aquifers are defined 
as potential drinking water sources by the South Carolina Pollution Control Act. DWS can be found at http://www.epa.gov/safewater/standards.html on the Internet. Other standards sometimes are applied by regulatory agencies to the SRS waste units under their jurisdiction. For example, standards under RCRA can include DWS, groundwater protection standards, background levels, or alternate concentration limits.

SRS responses to groundwater analytical results require careful evaluation of the data and relevant standards. Results from two constituents having DWS-dichloromethane and bis (2-ethylhexyl) phthalate - are evaluated more closely than other constituents and are commonly dismissed. Both are common laboratory contaminants and are reported in groundwater samples with little or no reproducibility. Both are reported, with appropriate flags and qualifiers, in detailed groundwater monitoring results that can be obtained by contacting the manager of the Washington Savannah River Company (WSRC) Environmental Permitting and Monitoring (EPM) group at 803-952-6931. Also, the SCDHEC standard used for lead is $50 \mu \mathrm{g} / \mathrm{L}$. The federal standard of $15 \mu \mathrm{g} / \mathrm{L}$ is a treatment standard for drinking water at the consumer's tap.

The regulatory standards for radionuclide discharges from industrial and governmental facilities are set under the Clean Water Act and under Nuclear Regulatory Commission and DOE regulations. In addition, radionuclide cleanup levels are included in the site RCRA permit under the authority of the South Carolina Pollution Control Act. The proposed drinking water maximum contaminant levels (MCLs) discussed in this report are only an adjunct to these release restrictions and are not used to regulate SRS groundwater.

Many potential radionuclide contaminants are beta emitters. The standard used for gross beta is a screening standard; when public drinking water exceeds this standard, the supplier is expected to analyze for individual beta and gamma emitters. A gross beta result above the standard is an indication that one or more radioisotopes are present in quantities that would exceed the EPA annual dose equivalent for persons consuming 2 liters daily. Thus, for the individual beta and gamma radioisotopes (other than strontium-90 and tritium), the standard considered is the activity per liter that would, if only that isotope were present, exceed the dose equivalent. Similarly, the standards for alpha emitters are calculated to present the same risk at the same rate of ingestion.

The element radium has several isotopes of concern in groundwater monitoring. Although radium has a DWS of $5 \mathrm{pCi} / \mathrm{L}$ for the sum of radium- 226 and radium-228, the isotopes have to be measured separately, and the combined numbers may not be representative of the total. Radium-226, an alpha emitter, and radium-228, a beta emitter, cannot be analyzed by a single method. Analyses for total alpha-emitting radium, which consists of radium223 , radium-224, and radium-226, are compared to the standard for radium-226.

Four other constituents without DWS are commonly used as indicators of potential contamination in wells.

These constituents are

- specific conductance at values equal to or greater than $100 \mu \mathrm{S} / \mathrm{cm}$

- alkalinity (as $\mathrm{CaCO} 3$ ) at values equal to or greater than $120 \mathrm{mg} / \mathrm{L}$

- total dissolved solids (TDS) at values equal to or greater than $500 \mathrm{mg} / \mathrm{L}$

- $\mathrm{pH}$ at values equal to or less than 6.5 or equal to or greater than 8.5 
The selection of these values as standards for comparison is somewhat arbitrary; however, the values exceed levels usually found in background wells at SRS. The occurrence of elevated alkalinity (as $\mathrm{CaCO} 3$ ), specific conductance, $\mathrm{pH}$, and TDS within a single well also may indicate leaching of the grouting material used in well construction, rather than degradation of the groundwater.

\section{Potential Dose}

The radiation protection standards followed by SRS are outlined in DOE Order 5400.5 and include EPA regulations on the potential doses from airborne releases and treated drinking water.

The following radiation dose standards for protection of the public in the SRS vicinity are specified in DOE Order 5400.5:

Drinking Water Pathway..... .4 mrem per year

Airborne Pathway 10 mrem per year

All Pathways 100 mrem per year

The EPA annual dose standard of $10 \mathrm{mrem}(0.1 \mathrm{mSv})$ for the atmospheric pathway, which is contained in 40 CFR 61, Subpart H, is adopted in DOE Order 5400.5.

These dose standards are based on recommendations of the ICRP and the National Council on Radiation Protection and Measurements.

The DOE dose standard enforced at SRS for drinking water is consistent with the criteria contained in "National Interim Primary Drinking Water Regulations, 40 CFR Part 141." Under these regulations, persons consuming drinking water shall not receive an annual total body or organ dose-DOE Order 5400.5 interprets this dose as committed effective dose equivalent - of more than $4 \mathrm{mrem}(0.04 \mathrm{mSv})$.

In 2000, EPA promulgated 40 CFR, Parts 9, 141, and 142, "National Primary Drinking Water Regulations; Radionuclides; Final Rule." This rule, which is applicable only to community drinking water systems, finalized MCLs for radionuclides, including uranium. In essence, it reestablishes the MCLs from EPA's original 1976 rule. Most of these MCLs are derived from dose conversion factors that are based on early ICRP-2 methods.

However, when calculating dose, SRS must use the more current ICRP-30-based dose conversion factors provided by DOE. Because they are based on different methods, most EPA and DOE radionuclide dose conversion factors differ. Therefore, a direct comparison of the drinking water doses calculated for showing compliance with DOE Order 5400.5 to the EPA drinking water MCLs cannot be made.

\section{Comparisons of Average Concentrations in Airborne Emissions to DOE Derived Concentration Guides}

Average concentrations of radionuclides in airborne emissions are calculated by dividing the yearly release total of each radionuclide from each stack by the yearly stack flow quantities. These average concentrations then can be compared to the DOE DCGs, which are found in DOE Order 5400.5 for each radionuclide. 
DCGs are used as reference concentrations for conducting environmental protection programs at all DOE sites. DCGs, which are based on a 100-mrem exposure, are applicable at the point of discharge (prior to dilution or dispersion) under conditions of continuous exposure (assumed to be an average inhalation rate of 8,400 cubic meters per year). This means that the DOE DCGs are based on the highly conservative assumption that a member of the public has direct access to, and continuously breathes (or is immersed in), the actual air effluent 24 hours a day, 365 days a year. However, because of the large distance between most SRS operating facilities and the site boundary, this scenario is improbable.

Average annual radionuclide concentrations in SRS air effluent can be referenced to DOE DCGs as a screening method to determine if existing effluent treatment systems are proper and effective.

\section{Comparison of Average Concentrations in Liquid Releases to DOE Derived Concentration Guides}

In addition to dose standards, DOE Order 5400.5 imposes other control considerations on liquid releases. These considerations are applicable to direct discharges but not to seepage basin and Solid Waste Disposal Facility migration discharges. The DOE order lists DCG values for most radionuclides. DCGs are used as reference concentrations for conducting environmental protection programs at all DOE sites. These DCG values are not release limits but screening values for best-available-technology investigations and for determining whether existing effluent treatment systems are proper and effective.

Per DOE Order 5400.5, exceedance of the DCGs at any discharge point may require an investigation of best-available-technology waste treatment for the liquid effluents. Tritium in liquid effluents is specifically excluded from best available technology requirements; however, it is not excluded from other ALARA considerations. DOE DCG compliance is demonstrated when the sum of the fractional DCG values for all radionuclides detectable in the effluent is less than 1.00, based on consecutive 12-month average concentrations.

DCGs, based on a 100-mrem exposure, are applicable at the point of discharge from the effluent conduit to the environment (prior to dilution or dispersion). They are based on the highly conservative assumption that a member of the public has continuous direct access to the actual liquid effluents and consumes 2 liters of the effluents every day, 365 days a year. Because of security controls and the considerable distances between most SRS operating facilities and the site boundary, this scenario is highly improbable, if not impossible.

For each SRS facility that releases radioactivity, the site's Environmental Permitting and Monitoring group compares the monthly liquid effluent concentrations and 12-month average concentrations against the DOE DCGs.

\section{Environmental Management}

SRS began its cleanup program in 1981. Two major federal statutes provide guidance for the site's environmental restoration and waste management activities-RCRA and CERCLA. RCRA addresses the management of hazardous waste and requires that permits be obtained for facilities that treat, store, or dispose of hazardous or mixed waste. It also requires that DOE facilities perform appropriate corrective action to address contaminants in the environment. CERCLA (also known as Superfund) addresses the uncontrolled release of hazardous substances and the cleanup of inactive waste sites. This act established 
a National Priority List of sites targeted for assessment and, if necessary, corrective/remedial action. SRS was placed on this list December 21, 1989 [Fact Sheet, 2000]. In August 1993, SRS entered into the Federal Facility Agreement (FFA) with EPA Region IV and SCDHEC. This agreement governs the corrective/remedial action process from site investigation through site remediation. It also describes procedures for setting annual work priorities, including schedules and deadlines, for that process [FFA under section 120 of CERCLA and sections 3008(h) and 6001 of RCRA].

Additionally, DOE is complying with Federal Facility Compliance Act requirements for mixed waste management - including high-level waste, most transuranic waste, and lowlevel waste with hazardous constituents. This act requires that DOE develop and submit site treatment plans to the EPA or state regulators for approval.

The disposition of facilities after they are declared excess to the government's mission is managed by Site Decommissioning and Demolition (D\&D) - formerly Facilities

Disposition Projects. The facility disposition process is conducted in accordance with DOE Order 430.1B, "Real Property Asset Management," and its associated guidance documents. The major emphases are reducing risks to workers and the public and minimizing real property asset lifecycle costs.

\section{Quality Assurance/Quality Control}

DOE Order 414.1C, "Quality Assurance," sets requirements and guidelines for departmental quality assurance (QA) practices. To ensure compliance with regulations and to provide overall quality requirements for site programs, WSRC developed its Quality Assurance Management Plan, Rev. 17 (WSRC-RP-92-225). The plan's requirements are implemented by the WSRC Quality Assurance Manual (WSRC 1Q).

The SRS Environmental Monitoring Section Quality Assurance Plan (WSRC-3Q1-2, Volume 3, Section 8000), was written to apply the QA requirements of WSRC 1Q to the environmental monitoring and surveillance program. The WSRC-3Q1 series includes procedures on sampling, radiochemistry, and water quality that emphasize the quality control requirements for EPM.

QA requirements for monitoring radiological air emissions are specified in 40 CFR 61, "National Emission Standards for Hazardous Air Pollutants." For radiological air emissions at SRS, the responsibilities and lines of communication are detailed in National Emission Standards for Hazardous Air Pollutants Quality Assurance Project Plan for Radionuclides (U) (WSRC-IM-91-60).

To ensure valid and defensible monitoring data, the records and data generated by the monitoring program are maintained according to the requirements of DOE Guide 1324.5B, "Implementation Guide for Use with 36 CFR Chapter XII - Subchapter B Records Management," and of WSRC 1Q. QA records include sampling and analytical procedure manuals, logbooks, chain-of-custody forms, calibration and training records, analytical notebooks, control charts, validated laboratory data, and environmental reports. These records are maintained and stored per the requirements of WSRC Retention Schedule Matrix (WSRC-EM-96-00023). 


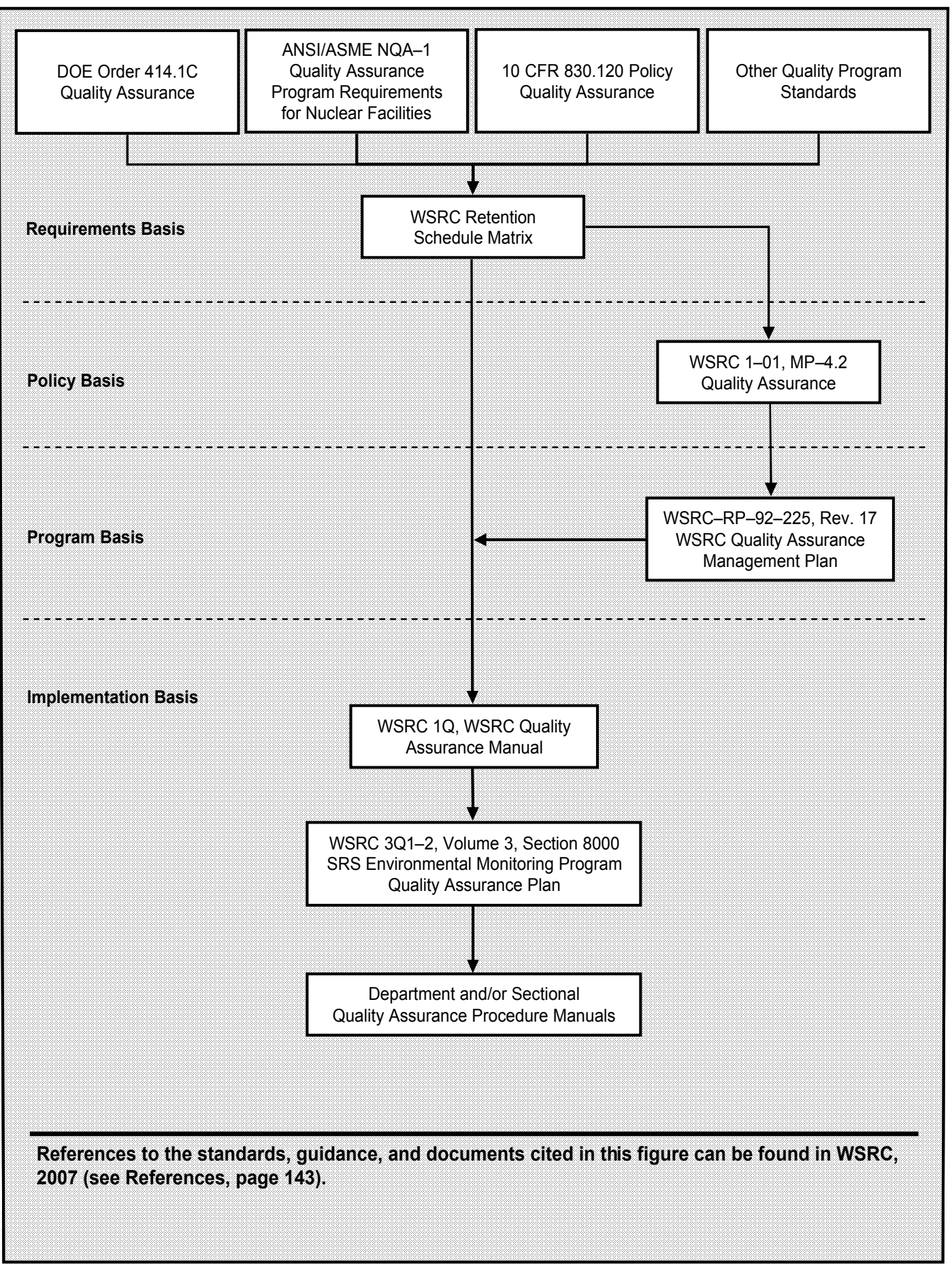

Figure A-1 SRS EM Program QA Document Hierarchy

This diagram depicts the hierarchy of relevant guidance and supporting documents for the SRS QA program. 
EPM assessments are implemented according to the following documents:

- DOE Order 414.1C

- DOE/EH-0173T

- DOE Environmental Management Consolidated Audit Program (EMCAP)

- WSRC 1Q, Quality Assurance Manual

- WSRC 12Q, Assessment Manual

\section{Reporting}

DOE Orders 231.1A, "Environment, Safety and Health Reporting," and 5400.5, "Radiation Protection of the Public and Environment," require that SRS submit an annual environmental report.

This report, the SRS Environmental Report for 2006, is an overview of effluent monitoring and environmental surveillance activities conducted on and in the vicinity of SRS from January 1 through December 31, 2006. 


\section{Radionuclide and Chemical Nomenclature}

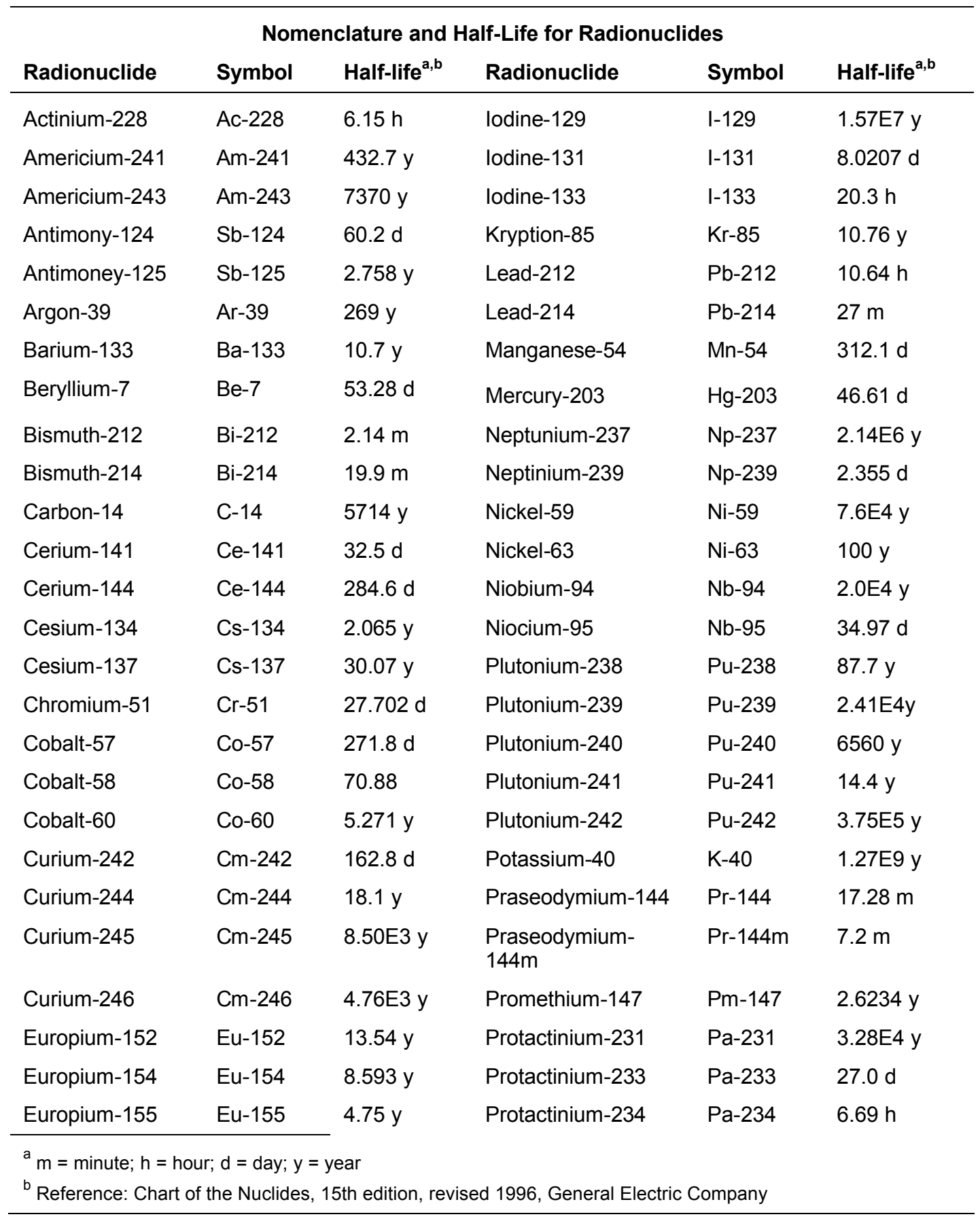




\begin{tabular}{|c|c|c|c|c|c|}
\hline \multicolumn{6}{|c|}{ Nomenclature and Half-Life for Radionuclides (cont.) } \\
\hline Radionuclide & Symbol & Half-life ${ }^{a, b}$ & Radionuclide & Symbol & Half-life $e^{a, b}$ \\
\hline Radium-226 & Ra-226 & 1599 y & Thorium-234 & Th-234 & $24.10 d$ \\
\hline Radium-228 & $\mathrm{Ra}-228$ & 5.76 y & Tin-113 & Sn-113 & $115.1 d$ \\
\hline Ruthenium-103 & Ru-103 & $39.27 d$ & Tin-126 & Sn-126 & $2.5 \mathrm{E} 5 \mathrm{y}$ \\
\hline Ruthenium-106 & Ru-106 & $1.020 \mathrm{y}$ & Tritium (Hydrogen-3) & $\mathrm{H}-3$ & 12.32 y \\
\hline Selenium-75 & Se-75 & $119.78 \mathrm{~d}$ & Uranium-232 & $\mathrm{U}-232$ & 69.8 y \\
\hline Selenium-79 & Se-79 & $6.5 \mathrm{E} 5 \mathrm{y}$ & Uranium-233 & $\mathrm{U}-233$ & $1.592 \mathrm{E} 5 \mathrm{y}$ \\
\hline Sodium-22 & $\mathrm{Na}-22$ & $2.604 \mathrm{y}$ & Uranium-234 & $\mathrm{U}-234$ & $2.46 \mathrm{E} 5 \mathrm{y}$ \\
\hline Strontium-89 & Sr-89 & $50.52 \mathrm{~d}$ & Uranium-235 & $\mathrm{U}-235$ & 7-04E8 Y \\
\hline Strontium-90 & Sr-90 & $28.78 y$ & Uranium-236 & U-236 & $2.342 \mathrm{E} 7 \mathrm{y}$ \\
\hline Technetium-99 & Tc-99 & 2.13E5 y & Uranium-238 & $\mathrm{U}-238$ & $4.47 \mathrm{E} 9 \mathrm{y}$ \\
\hline Thallium-208 & TI-208 & $3.053 \mathrm{~m}$ & Xenon-135 & Xe-135 & $9.10 \mathrm{~h}$ \\
\hline Thorium-228 & Th-228 & $1.913 y$ & Zinc-65 & Zn-65 & $243.8 d$ \\
\hline Thorium-230 & Th-230 & 7.54E4 y & Zirconium-85 & Zr-85 & $7.7 \mathrm{~m}$ \\
\hline Thorium-232 & Th-232 & $1,40 \mathrm{E} 10 \mathrm{y}$ & Zirconium-95 & Zr-95 & $64.02 \mathrm{~d}$ \\
\hline $\begin{array}{l}m=\text { minute; } \mathrm{h}= \\
\text { Reference: } \mathrm{Cha}\end{array}$ & $\begin{array}{l}=\text { day } \\
\text { e Nucl }\end{array}$ & $\begin{array}{l}\text { ar } \\
\text { th ec }\end{array}$ & $6, \mathrm{G}$ & $y$ & \\
\hline
\end{tabular}


Nomenclature for Elements and Chemical Constituent Analyses

Constituent Symbol Constituent Symbol

Note: Some of the symbols listed in this table came from various databases used to format the data tables in this report, and are included here to assist the reader in understanding the tables.

\begin{tabular}{|c|c|c|c|}
\hline Aluminum & $\mathrm{Al}$ (or $\mathrm{AL}$ ) & Nitrite, Nitrate & $\begin{array}{l}\mathrm{NO}_{2}, \mathrm{NO}_{3}\left(\text { or } \mathrm{NO}_{2},\right. \\
\left.\mathrm{NO}_{3} \text {, or } \mathrm{NO}_{2} / \mathrm{NO}_{3}\right)\end{array}$ \\
\hline Ammonia & $\mathrm{NH}_{3}$ & $\mathrm{pH}$ & $\mathrm{pH}$ (or $\mathrm{PH})$ \\
\hline Ammonia as Nitrogen & $\mathrm{NH}_{3}-\mathrm{N}($ or $\mathrm{AN})$ & Phenol & PHE \\
\hline Antimony & $\mathrm{Sb}$ (or SB) & Phosphorus & $\mathrm{P}$ \\
\hline Arsenic & As (or AS) & Phosphate & $\begin{array}{l}\mathrm{PO}_{4} \\
\left(\text { or } \mathrm{PO}_{4}-\mathrm{P} \text { or } \mathrm{PO}_{4}-\mathrm{P}\right)\end{array}$ \\
\hline Barium & $\mathrm{Ba}($ or $\mathrm{BA})$ & $\begin{array}{l}\text { Polychlorinated } \\
\text { Biphenyl }\end{array}$ & PCB \\
\hline $\begin{array}{l}\text { Biological Oxygen } \\
\text { Demand }\end{array}$ & BOD & Potassium & $\mathrm{K}$ \\
\hline Beryllium & $\mathrm{Be}$ & Selenium & Se (or SE) \\
\hline Boron & $\mathrm{B}$ & Silver & $\mathrm{Ag}$ (or $\mathrm{AG}$ ) \\
\hline Bromide & $\mathrm{Br}$ & Sulfate & $\mathrm{SO}_{4}\left(\right.$ or $\left.\mathrm{SO}_{4}\right)$ \\
\hline Cadmium & $\mathrm{Cd}$ ( or CD) & Tetrachloroethene & PERCL \\
\hline $\begin{array}{l}\text { Chemical Oxygen } \\
\text { Demand }\end{array}$ & COD & $\begin{array}{l}\text { Tetrachloroethylene } \\
\text { (Perchloroethylene) }\end{array}$ & PERCL \\
\hline Chlorine & $\mathrm{Cl}$ (or $\mathrm{CHL})$ & Trichloroethene & TRICL \\
\hline Chromium & $\mathrm{Cr}$ (or CR) & Trichloroethylene & TRICL \\
\hline Cobalt & Co & Tin & Sn \\
\hline Copper & $\mathrm{Cu}$ (or CU) & Total Dissolved Solids & TDS \\
\hline Cyanide & $\mathrm{CN}$ & Total Kjeldahl Nitrogen & TKN \\
\hline Dissolved Oxygen & DO & Total Organic Carbon & TOC \\
\hline Iron & $\mathrm{Fe}($ or FE) & $\begin{array}{l}\text { Total Suspended } \\
\text { Particulate Matter }\end{array}$ & TSP \\
\hline Lead & $\mathrm{Pb}$ (or PB) & $\begin{array}{l}\text { Total Suspended } \\
\text { Solids }\end{array}$ & TSS \\
\hline Magnesium & Mg (or MG) & Total Volatile Solids & TVS \\
\hline Manganese & $\mathrm{Mn}$ (or MN) & Uranium & U \\
\hline Mercury & $\mathrm{Hg}$ (or HG) & Vinyl Chloride & VC \\
\hline Molybdenum & Mo & Zinc & $\mathrm{Zn}$ (or ZN) \\
\hline Nickel & $\mathrm{Ni}($ or NI) & & \\
\hline Nitrate & $\mathrm{NO}_{3}$ & & \\
\hline Nitrate as Nitrogen & $\mathrm{NO}_{3}-\mathrm{N}$ & & \\
\hline Nitrite as Nitrogen & $\mathrm{NO}_{2}-\mathrm{N}$ & & \\
\hline
\end{tabular}





\section{Appendix C}

\section{Errata}

\section{From 2005 Report}

The following information was reported incorrectly in the Savannah River Site Environmental Report for 2005 (WSRC-TR-2006-00007):

- Environmental Data Table, "Toxic Air Pollutant Emissions (2004)"

The data in this table, which covered 2004 only, was provided and reported inaccurately. A revised table- "Toxic Air Pollutant Emissions (2003-2005)"covering three years of correct data appears in the Effluent Monitoring section of "Environmental Data - 2006" on the CD accompanying this report.

- Page 33, left column, paragraph 9

The combined tritium releases in 2005 should have been reported as 2,506 Ci, rather than 2,494 Ci.

- Page 33, left column, paragraph 10

The total tritium transport in SRS streams in 2005 should have been reported as 2,378 $\mathrm{Ci}$, rather than $2,364 \mathrm{Ci}$. 



\section{Glossary}

A

accuracy - Closeness of the result of a measurement to the true value of the quantity.

actinide - Group of elements of atomic number 89 through 103.

Laboratory analysis of actinides by alpha spectrometry generally refers to the elements plutonium, americium, uranium, and curium but may also include neptunium and thorium.

activity - See radioactivity.

air flow - Rate of flow, measured by mass or volume per unit of time.

air stripping - Process used to decontaminate groundwater by pumping the water to the surface, "stripping" or evaporating the chemicals in a specially designed tower, and pumping the cleansed water back to the environment.

aliquot - Quantity of sample being used for analysis.

alkalinity - Alkalinity is a measure of the buffering capacity of water, and since $\mathrm{pH}$ has a direct effect on organisms as well as an indirect effect on the toxicity of certain other pollutants in the water, the buffering capacity is important to water quality.

alpha particle - Positively charged particle emitted from the nucleus of an atom having the same charge and mass as that of a helium nucleus (two protons and two neutrons).

ambient air - Surrounding atmosphere as it exists around people, plants, and structures.

analyte - Constituent or parameter that is being analyzed.

analytical detection limit - Lowest reasonably accurate concentration of an analyte that can be detected; this value varies depending on the method, instrument, and dilution used.

aquifer - Saturated, permeable geologic unit that can transmit significant quantities of water under ordinary hydraulic gradients.

aquitard - Geologic unit that inhibits the flow of water. 
Atomic Energy Commission - Federal agency created in 1946 to manage the development, use, and control of nuclear energy for military and civilian application. It was abolished by the Energy Reorganization Act of 1974 and succeeded by the Energy Research and Development Administration. Functions of the Energy Research and Development Administration eventually were taken over by the U.S. Department of Energy and the U.S. Nuclear Regulatory Commission.

background radiation - Naturally occurring radiation, fallout, and cosmic radiation. Generally, the lowest level of radiation obtainable within the scope of an analytical measurement, i.e., a blank sample.

bailer - Container lowered into a well to remove water. The bailer is allowed to fill with water and then is removed from the well.

best management practices - Sound engineering practices that are not required by regulation or by law.

beta particle - Negatively charged particle emitted from the nucleus of an atom. It has a mass and charge equal to those of an electron.

blank - Control sample that is identical, in principle, to the sample of interest, except that the substance being analyzed is absent. In such cases, the measured value or signal for the substance being analyzed is believed to be due to artifacts. Under certain circumstances, that value may be subtracted from the measured value to give a net result reflecting the amount of the substance in the sample. The U.S. Environmental Protection Agency does not permit the subtraction of blank results in Environmental Protection Agency-regulated analyses.

blind blank - Sample container of deionized water sent to a laboratory under an alias name as a quality control check.

blind replicate - In the Environmental Services Section groundwater monitoring program, a second sample taken from the same well at the same time as the primary sample, assigned an alias well name, and sent to a laboratory for analysis (as an unknown to the analyst).

blind sample - Control sample of known concentration in which the expected values of the constituent are unknown to the analyst

calibration - Process of applying correction factors to equate a measurement to a known standard. Generally, a documented measurement control program of charts, graphs, and data that demonstrate that an instrument is properly calibrated. 
Carolina bay - Type of shallow depression commonly found on the coastal Carolina plains. Carolina bays are typically circular or oval. Some are wet or marshy, while others are dry.

Central Savannah River Area (CSRA) - Eighteen-county area in Georgia and South Carolina surrounding Augusta, Georgia. The Savannah River Site is included in the Central Savannah River Area. Counties are Richmond, Columbia, McDuffie, Burke, Emanuel, Glascock, Jenkins, Jefferson, Lincoln, Screven, Taliaferro, Warren, and Wilkes in Georgia and Aiken, Edgefield, Allendale, Barnwell, and McCormick in South Carolina.

chemical oxygen demand - Indicates the quantity of oxidizable materials present in a water and varies with water composition, concentrations of reagent, temperature, period of contact, and other factors.

chlorocarbons - Compounds of carbon and chlorine, or carbon, hydrogen, and chlorine, such as carbon tetrachloride, chloroform, tetrachloroethylene, etc. They are among the most significant and widespread environmental contaminants. Classified as hazardous wastes, chlorocarbons may have a tendency to cause detrimental effects, such as birth defects.

cleanup - Actions taken to deal with release or potential release of hazardous substances. This may mean complete removal of the substance; it also may mean stabilizing, containing, or otherwise treating the substance so that it does not affect human health or the environment.

\section{Comprehensive Environmental Response, Compensation, and}

Liability Act (CERCLA)- reportable release - Release to the environment that exceeds reportable quantities as defined by the Comprehensive Environmental Response, Compensation, and Liability Act.

concentration - Amount of a substance contained in a unit volume or mass of a sample.

conductivity - Measure of water's capacity to convey an electric current. This property is related to the total concentration of the ionized substances in a water and the temperature at which the measurement is made.

contamination - State of being made impure or unsuitable by contact or mixture with something unclean, bad, etc.

count - Signal that announces an ionization event within a counter; a measure of the radiation from an object or device.

counting geometry - Well-defined sample size and shape for which a counting system has been calibrated. 
criteria pollutant - Any of the pollutants commonly used as indices for air quality that can have a serious effect on human health and the environment, including sulfur dioxide, nitrogen dioxide, total suspended particulates, PM10, carbon monoxide, ozone, gaseous fluorides, and lead.

curie - Unit of radioactivity. One curie is defined as 3.7 x 1010 (37 billion) disintegrations per second. Several fractions and multiples of the curie are commonly used:

kilocurie (kCi) - $103 \mathrm{Ci}$, one thousand curies; 3.7 x 1013 disintegrations per second.

millicurie (mCi) - 10-3 Ci, one-thousandth of a curie; 3.7 x 107 disintegrations per second.

microcurie $(\boldsymbol{\mu C i})$ - 10-6 Ci, one-millionth of a curie; 3.7 x 104 disintegrations per second.

picocurie (pCi) - 10-12 Ci, one-trillionth of a curie; 0.037 disintegrations per second.

closure - Control of a hazardous waste management facility under Resource Conservation and Recovery Act requirements.

compliance - Fulfillment of applicable requirements of a plan or schedule ordered or approved by government authority.

composite - A blend of more than one portion to be used as a sample for analysis.

Comprehensive Environmental Response, Compensation, and Liability Act (CERCLA) - This act addresses the cleanup of hazardous substances and establishes a National Priority List of sites targeted for assessment and, if necessary, restoration (commonly known as "Superfund").

decay (radioactive) - Spontaneous transformation of one radionuclide into a different radioactive or nonradioactive nuclide, or into a different energy state of the same radionuclide.

decay time - Time taken by a quantity to decay to a stated fraction of its initial value.

deactivation - The process of placing a facility in a stable and known condition, including the removal of hazardous and radioactive materials to ensure adequate protection of the worker, public health and safety, and the 
environment - thereby limiting the long-term cost of surveillance and maintenance.

decommissioning - Process that takes place after deactivation and includes surveillance and maintenance, decontamination, and/or dismantlement.

decontamination - The removal or reduction of residual radioactive and hazardous materials by mechanical, chemical, or other techniques to achieve a stated objective or end condition.

decommissioning and demolition - Program that reduces the environmental and safety risks of surplus facilities at SRS.

derived concentration guide - Concentration of a radionuclide in air or water that, under conditions of continuous exposure for one year by one exposure mode (i.e., ingestion of water, submersion in air, or inhalation), would result in either an effective dose equivalent of $0.1 \mathrm{rem}(1 \mathrm{mSv})$ or a dose equivalent of $5 \mathrm{rem}(50 \mathrm{mSv})$ to any tissue, including skin and lens of the eye. The guides for radionuclides in air and water are given in U.S. Department of Energy Order 5400.5.

detection limit - See analytical detection limit, lower limit of detection, minimum detectable concentration.

detector - Material or device (instrument) that is sensitive to radiation and can produce a signal suitable for measurement or analysis.

diatometer - Diatom collection equipment consisting of a series of microscope slides in a holder that is used to determine the amount of algae in a water system.

diatoms - Unicellular or colonial algae of the class Bacillariophyceae, having siliceous cell walls with two overlapping, symmetrical parts. Diatoms represent the predominant periphyton (attached algae) in most water bodies and have been shown to be reliable indicators of water quality.

disposal - Permanent or temporary transfer of U.S. Department of Energy control and custody of real property to a third party, which thereby acquires rights to control, use, or relinquish the property.

disposition - Those activities that follow completion of program mission - including, but not limited to, surveillance and maintenance, deactivation, and decommissioning.

dissolved oxygen - Desirable indicator of satisfactory water quality in terms of low residuals of biologically available organic materials. Dissolved oxygen prevents the chemical reduction and subsequent leaching of iron and manganese from sediments. 
dose - Energy imparted to matter by ionizing radiation. The unit of absorbed dose is the rad, equal to 0.01 joules per kilogram in any medium. absorbed dose - Quantity of radiation energy absorbed by an organ, divided by the organ's mass. Absorbed dose is expressed in units of rad (or gray) $(1 \mathrm{rad}=0.01 \mathrm{~Gy})$.

dose equivalent - Product of the absorbed dose (rad) in tissue and a quality factor. Dose equivalent is expressed in units of rem (or sievert) (1 rem $=0.01$ sievert).

committed dose equivalent - Calculated total dose equivalent to a tissue or organ over a 50-year period after known intake of a radionuclide into the body. Contributions from external dose are not included. Committed dose equivalent is expressed in units of rem (or sievert).

committed effective dose equivalent - Sum of the committed dose equivalents to various tissues in the body, each multiplied by the appropriate weighting factor. Committed effective dose equivalent is expressed in units of rem (or sievert).

effective dose equivalent - Sum of the dose equivalents received by all organs or tissues of the body after each one has been multiplied by an appropriate weighting factor. The effective dose equivalent includes the committed effective dose equivalent from internal deposition of radionuclides and the effective dose equivalent attributable to sources external to the body.

collective dose equivalent/collective effective dose equivalent - Sums of the dose equivalents or effective dose equivalents of all individuals in an exposed population within a 50-mile $(80-\mathrm{km})$ radius, and expressed in units of person-rem (or person-sievert). When the collective dose equivalent of interest is for a specific organ, the units would be organ-rem (or organ-sievert). The 50-mile distance is measured from a point located centrally with respect to major facilities or U.S. Department of Energy program activities.

dosimeter - Portable detection device for measuring the total accumulated exposure to ionizing radiation.

downgradient - In the direction of decreasing hydrostatic head. drinking water standards - Federal primary drinking water standards, both proposed and final, as set forth by the U.S. Environmental Protection Agency.

duplicate result - Result derived by taking a portion of a primary sample and performing the identical analysis on that portion as is performed on the primary sample. 
effluent - Any treated or untreated air emission or liquid discharge to the environment.

effluent monitoring - Collection and analysis of samples or measurements of liquid and gaseous effluents for purpose of characterizing and quantifying the release of contaminants, assessing radiation exposures of members to the public, and demonstrating compliance with applicable standards.

environmental compliance - Actions taken in accordance with government laws, regulations, orders, etc., that apply to site operations' effects on onsite and offsite natural resources and on human health; used interchangeably in this document with regulatory compliance.

environmental monitoring - Program at Savannah River Site that includes effluent monitoring and environmental surveillance with dual purpose of (1) showing compliance with federal, state, and local regulations, as well as with U.S. Department of Energy orders, and (2) monitoring any effects of site operations on onsite and offsite natural resources and on human health.

environmental restoration - U.S. Department of Energy program that directs the assessment and cleanup of inactive waste units and groundwater (remediation) contaminated as a result of nuclear-related activities.

environmental surveillance - Collection and analysis of samples of air, water, soil, foodstuffs, biota, and other media from U.S. Department of Energy sites and their environs and the measurement of external radiation for purpose of demonstrating compliance with applicable standards, assessing radiation exposures to members of the public, and assessing effects, if any, on the local environment.

exceedance - Term used by the U.S. Environmental Protection Agency and the South Carolina Department of Health and Environmental Control that denotes a report value is more than the upper guide limit. This term is found on the discharge monitoring report forms that are submitted to the Environmental Protection Agency or the South Carolina Department of Health and Environmental Control.

exposure (radiation) - Incidence of radiation on living or inanimate material by accident or intent. Background exposure is the exposure to natural background ionizing radiation. Occupational exposure is the exposure to ionizing radiation that takes place during a person's working hours. Population exposure is the exposure to the total number of persons who inhabit an area. 
exposure pathway - Route that materials follow to get to the environment and then to people.

fallout - See worldwide fallout.

Federal Facility Agreement (FFA) - Agreement negotiated among the U.S. Department of Energy, the U.S. Environmental Protection Agency, and the South Carolina Department of Health and Environmental Control, specifying how the Savannah River Site will address contamination or potential contamination to meet regulatory requirements at site waste units identified for evaluation and, if necessary, cleanup.

feral hog - Hog that has reverted to the wild state from domestication.

gamma ray - High-energy, short-wavelength electromagnetic radiation emitted from the nucleus of an excited atom. Gamma rays are identical to $\mathrm{X}$-rays except for the source of the emission.

gamma-emitter - Any nuclide that emits a gamma ray during the process of radioactive decay. Generally, the fission products produced in nuclear reactors.

gamma spectrometry - System consisting of a detector, associated electronics, and a multichannel analyzer that is used to analyze samples for gamma-emitting radionuclides.

grab sample - Sample collected instantaneously with a glass or plastic bottle placed below the water surface to collect surface water samples (also called dip samples).

half-life (radiological) - Time required for half of a given number of atoms of a specific radionuclide to decay. Each nuclide has a unique halflife.

heavy water - Water in which the molecules contain oxygen and deuterium, an isotope of hydrogen that is heavier than ordinary hydrogen.

hydraulic gradient - Difference in hydraulic head over a specified distance. 
hydrology - Science that treats the occurrence, circulation, distribution, and properties of the waters of the earth, and their reaction with the environment.

in situ - In its original place. Field measurements taken without removing the sample from its origin; remediation performed while groundwater remains below the surface.

inorganic - Involving matter other than plant or animal.

instrument background - Instrument signal due to electrical noise and other interferences not attributed to the sample or blank.

ion exchange - Process in which a solution containing soluble ions is passed over a solid ion exchange column that removes the soluble ions by exchanging them with labile ions from the surface of the column. The process is reversible so that the trapped ions are removed (eluted) from the column and the column is regenerated.

irradiation - Exposure to radiation.

isotopes - Forms of an element having the same number of protons in their nuclei but differing in the number of neutrons.

long-lived isotope - Radionuclide that decays at such a slow rate that a quantity of it will exist for an extended period (half-life is greater than three years).

short-lived isotope - Radionuclide that decays so rapidly that a given quantity is transformed almost completely into decay products within a short period (half-life is two days or less).

laboratory blank - Deionized water sample generated by the laboratory; a laboratory blank is analyzed with each batch of samples as an in-house check of analytical procedures. Also called an internal blank.

legacy - Anything handed down from the past; inheritance, as of nuclear waste.

lower limit of detection - Smallest concentration/amount of an analyte that can be reliably detected in a sample at a 95-percent confidence level.

macroinvertebrates - Size-based classification used for a variety of insects and other small invertebrates; as defined by the U.S. Environmental 
Protection Agency, those organisms that are retained by a No. 30 (590micron) U.S. Standard Sieve.

macrophyte - A plant that can be observed with the naked eye.

manmade radiation - Radiation from sources such as consumer products, medical procedures, and nuclear industry.

maximally exposed individual - Hypothetical individual who remains in an uncontrolled area and would, when all potential routes of exposure from a facility's operations are considered, receive the greatest possible dose equivalent.

mean relative difference - Percentage error based on statistical analysis.

mercury - Silver-white, liquid metal solidifying at $-38.9^{\circ} \mathrm{C}$ to form a tinwhite, ductile, malleable mass. It is widely distributed in the environment and biologically is a nonessential or nonbeneficial element. Human poisoning due to this highly toxic element has been clinically recognized.

migration - Transfer or movement of a material through the air, soil, or groundwater.

minimum detectable concentration - Smallest amount or concentration of a radionuclide that can be distinguished in a sample by a given measurement system at a preselected counting time and at a given confidence level.

moderate - To reduce the excessiveness of; to act as a moderator.

moderator - Material, such as heavy water, used in a nuclear reactor to moderate or slow down neutrons from the high velocities at which they are created in the fission process.

monitoring - Process whereby the quantity and quality of factors that can affect the environment and/or human health are measured periodically to regulate and control potential impacts.

nonroutine radioactive release - Unplanned or nonscheduled release of radioactivity to the environment.

nuclide - Atom specified by its atomic weight, atomic number, and energy state. A radionuclide is a radioactive nuclide.

opacity - The reduction in visibility of an object or background as viewed through the diameter of a plume. 
organic - Of, relating to, or derived from living organisms (plant or animal).

outcrop - Place where groundwater is discharged to the surface. Springs, swamps, and beds of streams and rivers are the outcrops of the water table.

outfall - Point of discharge (e.g., drain or pipe) of wastewater or other effluents into a ditch, pond, or river.

parameter - Analytical constituent; chemical compound(s) or property for which an analytical request may be submitted.

permeability - Physical property that describes the ease with which water may move through the pore spaces and cracks in a solid.

person-rem - Collective dose to a population group. For example, a dose of one rem to 10 individuals results in a collective dose of 10 person-rem.

pH - Measure of the hydrogen ion concentration in an aqueous solution. Acidic solutions have a $\mathrm{pH}$ from 0 to 6 , basic solutions have a $\mathrm{pH}>7$, and neutral solutions have a $\mathrm{pH}=7$.

piezometer - Instrument used to measure the potentiometric surface of the groundwater. Also, a well designed for this purpose.

plume - Volume of contaminated air or water originating at a point-source emission (e.g., a smokestack) or at a waste source (e.g., a hazardous waste disposal site).

point source - Any defined source of emission to air or water such as a stack, air vent, pipe, channel, or passage to a water body.

population dose - See collective dose equivalent under dose.

process sewer - Pipe or drain, generally located underground, used to carry off process water and/or waste matter.

purge - To remove water prior to sampling, generally by pumping or bailing.

purge water - Water that has been removed prior to sampling; water that has been released to seepage basins to allow a significant part of tritium to decay before the water outcrops to surface streams and flows to the Savannah River.

quality assurance (QA) - In the Environmental Monitoring System program, QA consists of the system whereby the laboratory can assure 
clients and other outside entities, such as government agencies and accrediting bodies, that the laboratory is generating data of proven and known quality.

quality control (QC) - In the Environmental Monitoring System program, QC refers to those operations undertaken in the laboratory to ensure that the data produced are generated within known probability limits of accuracy and precision.

rad - Unit of absorbed dose deposited in a volume of material.

radioactivity - Spontaneous emission of radiation, generally alpha or beta particles, or gamma rays, from the nucleus of an unstable isotope.

radioisotopes - Radioactive isotopes.

radionuclide - Unstable nuclide capable of spontaneous transformation into other nuclides by changing its nuclear configuration or energy level. This transformation is accompanied by the emission of photons or particles.

real-time instrumentation - Operation in which programmed responses to an event essentially are simultaneous to the event itself.

reforestation - Process of planting new trees on land once forested.

regulatory compliance - Actions taken in accordance with government laws, regulations, orders, etc., that apply to Savannah River Site operations' effects on onsite and offsite natural resources and on human health; used interchangeably in this document with environmental compliance.

release - Any discharge to the environment. Environment is broadly defined as any water, land, or ambient air.

rem - Unit of dose equivalent (absorbed dose in rads $\mathrm{x}$ the radiation quality factor). Dose equivalent frequently is reported in units of millirem (mrem), which is one-thousandth of a rem.

remediation - Assessment and cleanup of U.S. Department of Energy sites contaminated with waste as a result of past activities. See environmental restoration.

remediation design - Planning aspects of remediation, such as engineering characterization, sampling studies, data compilation, and determining a path forward for a waste site. 
replicate - In the Environmental Services Section groundwater monitoring program, a second sample from the same well taken at the same time as the primary sample and sent to the same laboratory for analysis.

Resource Conservation and Recovery Act (RCRA) Federal legislation that regulates the transport, treatment, and disposal of solid and hazardous wastes. This act also requires corrective action for releases of hazardous waste at inactive waste units.

Resource Conservation and Recovery Act (RCRA) site - Solid waste management unit under Resource Conservation and Recovery Act regulation. See Resource Conservation and Recovery Act.

retention basin - Unlined basin used for emergency, temporary storage of potentially contaminated cooling water from chemical separations activities.

RFI/RI Program - RCRA Facility Investigation/Remedial Investigation Program. At the Savannah River Site, the expansion of the RFI Program to include Comprehensive Environmental Response, Compensation, and Liability Act and hazardous substance regulations.

routine radioactive release - Planned or scheduled release of radioactivity to the environment.

seepage basin - Excavation that receives wastewater. Insoluble materials settle out on the floor of the basin and soluble materials seep with the water through the soil column, where they are removed partially by ion exchange with the soil. Construction may include dikes to prevent overflow or surface runoff.

sensitivity - Capability of methodology or instruments to discriminate between samples with differing concentrations or containing varying amounts of analyte.

settling basin - Temporary holding basin (excavation) that receives wastewater that subsequently is discharged.

site stream - Any natural stream on the Savannah River Site. Surface drainage of the site is via these streams to the Savannah River.

source - Point or object from which radiation or contamination emanates.

source check - Radioactive source (with a known amount of radioactivity) used to check the performance of the radiation detector instrument. 
source term - Quantity of radioactivity (released in a set period of time) that is traceable to the starting point of an effluent stream or migration pathway.

spent nuclear fuel - Used fuel elements from reactors.

spike - Addition, to a blank sample, of a known amount of reference material containing the analyte of interest.

stable - Not radioactive or not easily decomposed or otherwise modified chemically.

stack - Vertical pipe or flue designed to exhaust airborne gases and suspended particulate matter.

standard deviation - Indication of the dispersion of a set of results around their average.

stormwater runoff - Surface streams that appear after precipitation.

Superfund - See Comprehensive Environmental Response, Compensation, and Liability Act (CERCLA).

supernate - Portion of a liquid above settled materials in a tank or other vessel.

surface water - All water on the surface of the earth, as distinguished from groundwater.

tank farm - Installation of interconnected underground tanks for storage of high-level radioactive liquid wastes.

temperature - Thermal state of a body, considered with its ability to communicate heat to other bodies.

thermoluminescent dosimeter (TLD) - Device used to measure external gamma radiation.

total dissolved solids - Dissolved solids and total dissolved solids are terms generally associated with freshwater systems; they consist of inorganic salts, small amounts of organic matter, and dissolved materials.

total phosphorus - May occasionally stimulate excessive or nuisance growths of algae and other aquatic plants when concentrations exceed 25 $\mathrm{mg} / \mathrm{L}$ at the time of the spring turnover on a volume-weighted basis in lakes or reservoirs. 
total suspended particulates - Refers to the concentration of particulates in suspension in the air, regardless of the nature, source, or size of the particulates.

transport pathway - Pathway by which a released contaminant is transported physically from its point of discharge to a point of potential exposure to humans. Typical transport pathways include the atmosphere, surface water, and groundwater.

transuranic waste - Solid radioactive waste containing primarily alphaemitting elements heavier than uranium.

trend - General drift, tendency, or pattern of a set of data plotted over time.

turbidity - Measure of the concentration of sediment or suspended particles in solution.

unspecified alpha and beta emissions - The unidentified alpha and beta emissions that are determined at each effluent location by subtracting the sum of the individually measured alpha-emitting (e.g., plutonium-239 and uranium-235) and beta-emitting (e.g., cesium-137 and strontium-90) radionuclides from the measured gross alpha and beta values, respectively.

vitrify - Change into glass.

vitrification - Process of changing into glass.

volatile organic compounds - Broad range of organic compounds, commonly halogenated, that vaporize at ambient, or relatively low, temperatures (e.g., acetone, benzene, chloroform, and methyl alcohol).

waste management - The U.S. Department of Energy uses this term to refer to the safe, effective management of various kinds of nonhazardous, hazardous, and radioactive waste generated at Savannah River Site.

waste unit - An inactive area known to have received contamination or to have had a release to the environment.

water table - Planar, underground surface beneath which earth materials, such as soil or rock, are saturated with water.

weighting factor - Value used to calculate dose equivalents. It is tissue specific and represents the fraction of the total health risk resulting from 
uniform, whole-body irradiation that could be attributed to that particular tissue. The weighting factors used in this report are recommended by the International Commission on Radiological Protection (Publication 26).

wetland - Lowland area, such as a marsh or swamp, inundated or saturated by surface or groundwater sufficiently to support hydrophytic vegetation typically adapted for life in saturated soils.

wind rose - Diagram in which statistical information concerning wind direction and speed at a location is summarized.

worldwide fallout - Radioactive debris from atmospheric weapons tests that has been deposited on the earth's surface after being airborne and cycling around the earth. 


\section{References}

Aadland et al., 1995 Aadland, R.K., J.A. Gellici, and P.A. Thayer, 1995, "Hydrogeologic Framework of West-Central South Carolina," Report 5, Water Resources Division, South Carolina Department of Natural Resources, Columbia, S.C.

Carlton et al., 1994 Carlton, W.H., C.E. Murphy, Jr., and A.G. Evans, 1994,

"Radiocesium in the Savannah River Site Environment," Health Physics, Volume 67, Number 3, Williams \& Wilkins, Baltimore, Md.

Cherry, 2006 Cherry, G.S., 2006, "Simulation and Particle-Tracking Analysis of Ground-Water Flow near the Savannah River Site, Georgia and South Carolina, 2002, and for Selected Ground-Water Management Scenarios, 2002 and 2020," Scientific Investigations Report, 2006-5195, U.S. Geological Survey, Reston, Virginia.

Clarke and West, 1998 Clarke, J.S., and C.T. West, 1998, "Ground-Water Levels, Predevelopment Ground-Water Flow, and Stream-Aquifer Relations in the Vicinity of the Savannah River Site, Georgia and South Carolina," U.S. Geological Survey WaterResources Investigations Report 974197, U.S. Geological Survey, Reston, Va.

DOE, 1988 U.S. Department of Energy, 1988, External and Internal Dose Conversion Factors for Calculation of Dose to the Public, DOE/EH-0070 \& 71, Washington, D.C.

DOE, 2002 U.S. Department of Energy, 2002, A Graded Approach for Evaluating Radiation Doses to Aquatic and Terrestrial Biota, DOE Standard, DOE-STD-1153-2002, July 2002, Washington, D.C.

EPA, 1999 U.S. Environmental Protection Agency, 1999, Cancer Risk Coefficients for Environmental Exposure to Radionuclides, Federal Guidance Report No.13, EPA 402-R99-001, September 1999, Washington, D.C.

EPA, 2002 U.S. Environmental Protection Agency, 2002, "National Emission Standards for Hazardous Air Pollutants," Title 40 Code of Federal Regulations, Part 61, Subpart H, September 2002, Washington, D.C.

Fact Sheet, 2000 Westinghouse Savannah River Company, 2000, "Environmental Restoration," Fact Sheet, www.srs.gov/general/aboutsrs/pubrel/factsheets/hlwtf7.pdf, Savannah River Site, Aiken, S.C.

Fallaw and Price, 1995 Fallaw, W.C., and V. Price, 1995, "Stratigraphy of the Savannah River Site and Vicinity," Southeastern Geology, Vol. 35, No. 1, March 1995, pp. 21-58, Duke University, Durham, N.C.

Hamby, 1991 Hamby, D.M., 1991, Land and Water Use Characteristics in the Vicinity of the Savannah River Site (U), WSRC-RP-91-17, Savannah River Site, Aiken, S.C. 
Hamby and Bauer, 1994 Hamby, D.M., and L.R. Bauer, 1994, "The Vegetation-to-Air Concentration Ratio in a Specific Activity Atmospheric Tritium Model," Health Physics, Volume 66, Number 3, Williams \& Wilkins, Baltimore, Md.

NRC, 1977 U.S. Nuclear Regulatory Commission, 1977, Regulatory Guide 1.109, Calculation of Annual Doses to Man from Routine Releases of Reactor Effluents for the Purpose of Evaluating Compliance with 10 CFR 50, Appendix I, Revision 1, Washington, D.C.

SCDHEC, 2004 South Carolina Department of Health and Environmental Control, 2004, "Water Classifications and Standards," South Carolina Code of Regulations, R.61-68, Columbia, S.C.

Smits et al., 1996 Smits, A.D., M.K. Harris, K.L. Hawkins, and G.P. Flach, 1996, "Integrated Hydrogeological Model of the General Separations Area, Volume 1:

Hydrogeological Framework," WSRC-TR-96-0399, Revision 0, Westinghouse Savannah River Company, Aiken, S.C.

SRS EM Program, 2001 Savannah River Site Environmental Monitoring Section Plans and Procedures, 2001, WSRC-3Q1-2, Volume 1, Section 1100, Savannah River Site, Aiken, S.C.

WSRC, 2007 Washington Savannah River Company, 2007, WSRC Quality Assurance Manual, WSRC-1Q, Savannah River Site, Aiken, SC.

Yu et al., 2001 C. Yu, A.J. Zielen, J.J. Cheng, D.J. LePoire, E. Gnanapragasam, S. Kamboj, Arnish, A.Wallo III, W.A. Williams, and H. Peterson, Users Manual for RESRAD Version 6, Argonne National Laboratory Report, ANL/EAD/4, July 2001, Argonne, Ill. 


\begin{tabular}{|c|c|c|c|}
\hline \multicolumn{2}{|c|}{ Units of Measure } & \multicolumn{2}{|c|}{ Units of Measure } \\
\hline Symbol & Name & Symbol & Name \\
\hline Temperature & & Concentration & \\
\hline${ }^{\circ} \mathrm{C}$ & degrees Centigrade & $\mathrm{ppb}$ & parts per billion \\
\hline${ }^{\circ} \mathrm{F}$ & degrees Fahrenheit & ppm & parts per million \\
\hline \multicolumn{4}{|l|}{ Time } \\
\hline$d$ & day & Rate & \\
\hline $\mathrm{h}$ & hour & cfs & cubic feet per second \\
\hline y & year & gpm & gallons per minute \\
\hline \multicolumn{4}{|l|}{ Length } \\
\hline $\mathrm{cm}$ & centimeter & Conductivity & \\
\hline $\mathrm{ft}$ & foot & $\mu \mathrm{mho}$ & micromho \\
\hline in & inch & & \\
\hline $\mathrm{km}$ & kilometer & & \\
\hline $\mathrm{m}$ & meter & Radioactivity & \\
\hline $\mathrm{mm}$ & millimeter & $\mathrm{Ci}$ & curie \\
\hline \multirow[t]{2}{*}{$\mu \mathrm{m}$} & micrometer & $\mathrm{cpm}$ & counts per minute \\
\hline & & $\mathrm{mCi}$ & millicurie \\
\hline Mass & & $\mu \mathrm{Ci}$ & microcurie \\
\hline$g$ & gram & $\mathrm{pCi}$ & picocurie \\
\hline $\mathrm{kg}$ & kilogram & $\mathrm{Bq}$ & becquerel \\
\hline $\mathrm{mg}$ & milligram & & \\
\hline \multirow[t]{2}{*}{$\mu \mathrm{g}$} & microgram & & \\
\hline & & Radiation Dose & \\
\hline Area & & mrad & millirad \\
\hline $\mathrm{mi}^{2}$ & square mile & mrem & millirem \\
\hline \multirow[t]{2}{*}{$\mathrm{ft}^{2}$} & square foot & Sv & sievert \\
\hline & & $\mathrm{mSv}$ & millisievert \\
\hline Volume & & $\mu \mathrm{Sv}$ & microsievert \\
\hline gal & gallon & $\mathrm{R}$ & roentgen \\
\hline L & liter & $\mathrm{mR}$ & milliroentgen \\
\hline \multirow[t]{2}{*}{$\mathrm{mL}$} & milliliter & $\mu \mathrm{R}$ & microroentgen \\
\hline & & Gy & gray \\
\hline
\end{tabular}




\begin{tabular}{|cclll|}
\hline \multicolumn{5}{c}{ Fractions and Multiples of Units } \\
\hline Multiple & Decimal Equivalent & Prefix & Symbol & $\begin{array}{l}\text { Report } \\
\text { Format }\end{array}$ \\
\hline $10^{6}$ & $1,000,000$ & mega- & $\mathrm{M}$ & $\mathrm{E}+06$ \\
$10^{3}$ & 1,000 & kilo- & $\mathrm{k}$ & $\mathrm{E}+03$ \\
$10^{2}$ & 100 & hecto- & $\mathrm{h}$ & $\mathrm{E}+02$ \\
10 & 10 & deka- & da & $\mathrm{E}+01$ \\
$10^{-1}$ & 0.1 & deci- & $\mathrm{d}$ & $\mathrm{E}-01$ \\
$10^{-2}$ & 0.01 & centi- & $\mathrm{c}$ & $\mathrm{E}-02$ \\
$10^{-3}$ & 0.001 & milli- & $\mathrm{m}$ & $\mathrm{E}-03$ \\
$10^{-6}$ & 0.000001 & micro- & $\mu$ & $\mathrm{E}-06$ \\
$10^{-9}$ & 0.000000001 & nano- & $\mathrm{n}$ & $\mathrm{E}-09$ \\
$10^{-12}$ & 0.000000000001 & pico- & $\mathrm{p}$ & $\mathrm{E}-12$ \\
$10^{-15}$ & 0.000000000000001 & femto- & $\mathrm{f}$ & $\mathrm{E}-15$ \\
$10^{-18}$ & 0.000000000000000001 & atto- & $\mathrm{a}$ & $\mathrm{E}-18$ \\
\hline
\end{tabular}

\begin{tabular}{|lll|}
\hline \multicolumn{3}{|c|}{ Conversion Table (Units of Radiation Measure) } \\
\hline Current System & Systéme International & Conversion \\
\hline curie (Ci) & becquerel $(\mathrm{Bq})$ & $1 \mathrm{Ci}=3.7 \times 10^{10} \mathrm{~Bq}$ \\
rad (radiation absorbed dose) & gray (Gy) & $1 \mathrm{rad}=0.01 \mathrm{~Gy}$ \\
rem (roentgen equivalent man) & sievert (Sv) & $1 \mathrm{rem}=0.01 \mathrm{~Sv}$ \\
\hline
\end{tabular}

\begin{tabular}{|lll|lcl|}
\hline \multicolumn{5}{c|}{ Conversion Table } \\
\hline Multiply & By & To Obtain & Multiply & By & To Obtain \\
\hline in. & 2.54 & $\mathrm{~cm}$ & $\mathrm{~cm}$ & 0.394 & $\mathrm{in.}$ \\
$\mathrm{ft}$ & 0.305 & $\mathrm{~m}$ & $\mathrm{~m}$ & 3.28 & $\mathrm{ft}$ \\
$\mathrm{mi}$ & 1.61 & $\mathrm{~km}$ & $\mathrm{~km}$ & 0.621 & $\mathrm{mi}$ \\
$\mathrm{lb}$ & 0.4536 & $\mathrm{~kg}$ & $\mathrm{~kg}$ & 2.205 & $\mathrm{lb}$ \\
$\mathrm{liq} \mathrm{qt}-$ U.S. & 0.946 & $\mathrm{~L}$ & $\mathrm{~L}$ & 1.057 & $\mathrm{liq} \mathrm{qt}-\mathrm{U} . \mathrm{S}$. \\
$\mathrm{ft}^{2}$ & 0.093 & $\mathrm{~m}^{2}$ & $\mathrm{~m}^{2}$ & 10.764 & $\mathrm{ft}^{2}$ \\
$\mathrm{mi}^{2}$ & 2.59 & $\mathrm{~km}^{2}$ & $\mathrm{~km}^{2}$ & 0.386 & $\mathrm{mi}^{2}$ \\
$\mathrm{ft}^{3}$ & 0.028 & $\mathrm{~m}^{3}$ & $\mathrm{~m}^{3}$ & 35.31 & $\mathrm{ft}^{3}$ \\
$\mathrm{~d} / \mathrm{m}$ & 0.450 & $\mathrm{pCi}$ & $\mathrm{pCi}$ & 2.22 & $\mathrm{~d} / \mathrm{m}$ \\
$\mathrm{pCi}$ & $10^{-6}$ & $\mu \mathrm{Ci}$ & $\mu \mathrm{Ci}$ & $10^{6}$ & $\mathrm{pCi}$ \\
$\mathrm{pCi} / \mathrm{L}$ (water) & $10^{-9}$ & $\mu \mathrm{Ci} / \mathrm{mL}$ (water) & $\mu \mathrm{Ci} / \mathrm{mL}$ (water) & $10^{9}$ & $\mathrm{pCi} / \mathrm{L}$ (water) \\
$\mathrm{pCi} / \mathrm{m}^{3}$ (air) & $10^{-12}$ & $\mu \mathrm{Ci} / \mathrm{mL}$ (air) & $\mu \mathrm{Ci} / \mathrm{mL}$ (air) & $10^{12}$ & $\mathrm{pCi} / \mathrm{m}^{3}$ (air) \\
& & & & \\
\hline
\end{tabular}

